\title{
The Long Search for Stability: Financial Cooperation to Address Global Risks in the East Asian Region ${ }^{\dagger}$
}

\author{
C.P. Chandrasekhar*
}

\section{Working Paper No. 153}

\author{
March 31 ${ }^{\text {st }}, 2021$
}

\begin{abstract}
Forced by the 1997 Southeast Asian crisis to recognize the external vulnerabilities that openness to volatile capital flows result in and upset over the post-crisis policy responses imposed by the IMF, countries in the sub-region saw the need for a regional financial safety net that can pre-empt or mitigate future crises. At the outset, the aim of the initiative, then led by Japan, was to create a facility or design a mechanism that was independent of the United States and the IMF, since the former was less concerned with vulnerabilities in Asia than it was in Latin America and that the latter's recommendations proved damaging for countries in the region. But US opposition and inherited geopolitical tensions in the region blocked Japan's initial proposal to establish an Asian Monetary Fund, a kind of regional IMF. As an alternative, the ASEAN+3 grouping (ASEAN members plus China, Japan and South Korea) opted for more flexible arrangements, at the core of which was a network of multilateral and bilateral central
\end{abstract}

\footnotetext{
$\dagger$ This study was supported with a grant from INET. I must thank Thomas Ferguson for encouraging me to take up this study and for commenting on earlier drafts of this essay. Detailed comments from Perry Mehrling, Jayati Ghosh, Vikas Rawal, Anwesh Mukherjee and an anonymous referee are also gratefully acknowledged. This author, however, is solely responsible for the final product and any errors that remain.
}

* Former Professor, Jawaharlal Nehru University, New Delhi. 
bank swap agreements. While central bank swap agreements have played a role in crisis management, the effort to make them the central instruments of a cooperatively established regional safety net, the Chiang Mai Initiative, failed. During the crises of 2008 and 2020 countries covered by the Initiative chose not to rely on the facility, preferring to turn to multilateral institutions such as the ADB, World Bank and IMF or enter into bilateral agreements within and outside the region for assistance. The fundamental problem was that because of an effort to appease the US and the IMF and the use of the IMF as a foil against the dominance of a regional power like Japan, the regional arrangement was not a real alternative to traditional sources of balance of payments support. In particular, access to significant financial assistance under the arrangement required a country to be supported first by an IMF program and be subject to the IMF's conditions and surveillance. The failure of the multilateral effort meant that a specifically Asian safety net independent of the US and the IMF had to be one constructed by a regional power involving support for a network of bilateral agreements. Japan was the first regional power to seek to build such a network through it post-1997 Miyazawa Initiative. But its own complex relationship with the US meant that its intervention could not be sustained, more so because of the crisis that engulfed Japan in 1990. But the prospect of regional independence in crisis resolution has revived with the rise of China as a regional and global power. This time both economics and China's independence from the US seem to improve prospects of successful regional cooperation to address financial vulnerability. A history of tensions between China and its neighbours and the fear of Chinese dominance may yet lead to one more failure. But, as of now, the Belt and Road Initiative, China's support for a large number of bilateral swap arrangements and its participation in the Regional Comprehensive Economic Partnership seem to suggest that Asian countries may finally come into their own.

https://doi.org/10.36687/inetwp153

JEL codes: F32, F33, F36, F65

Key words: Financial Globalization, Financial Integration, Financial Liberalization, Financial Crises, Regional Cooperation, Central Bank Swaps, Chiang Mai Initiative, Bilateral Swap Arrangements. 


\section{The Issue}

The Southeast Asian financial crisis, which engulfed a part of Asia in 1997, adversely affected what were thought to be the most successful developing countries with strong macroeconomic fundamentals. A defining feature of the crisis was that, though signaled by balance of payments vulnerability and currency collapse, it was principally triggered by an inability to meet commitments associated with capital account liabilities and not by weaknesses on the trade account. In fact, some of the major countries involved had, as a result of the pursuit of mercantilist strategies, notched up trade surpluses in years preceding the crisis.

A second noteworthy feature of the crisis was that the liabilities that underlay the crisis were not incurred principally on the government account, as was largely the case in Latin America at the time of the debt crises of the 1980s, but were substantially private liabilities to private international financial markets abroad. These liabilities were to an extent self-fueled, as new flows of portfolio capital and debt partly contributed to the rollover of past liabilities and even financed payment commitments on accumulated liabilities.

These features of the crisis have a larger relevance. In the case of the developed countries, for quite some time, private financial markets had been the first source of funds to cover a nation's need for foreign currency, especially dollar liquidity, taking precedence over central banks swaps, IMF support and even own reserves. In fact, it has been argued that central banks swaps and own reserves are only backstops, the existence of which creates the confidence that ensures flows of private capital through financial markets to cover financing needs. They are not used in normal times and may be availed of at most in times of crisis (Mehrling 2015).

However, before the capital flows surge and financial liberalization wave of the 1980s, developing countries (barring one $)^{1}$ did not have access to private international financial markets. Foreign exchange access was determined by flows through the bilateral and multilateral aid and lending networks, as well as foreign direct investment, with the magnitude of that access being determined wholly from the supply side. It was only from the 1980s, when an international financial system awash with liquidity turned to the so-called "emerging markets" as lending targets and investment destinations, that some countries in the developing world also obtained access to international private financial markets. What the crises in Latin America and then Asia in the 1980s and 1990s showed, was that the financial openness this access encouraged soon led to financial instability and balance of payments vulnerability. That experience made the vulnerabilities that characterize a world of free and substantially enhanced cross-border financial flows the focus of policy attention.

Despite this experience, there was little mainstream support for a reversal of open-door policies governing cross-border financial flows after the Southeast Asian crisis broke. Other than for short-lived experiments in Malaysia, the consensus in the region was that a turn away from liberalized rules regarding cross-border financial flows was both infeasible and unwarranted.

The period since the 1997 crisis has witnessed the intensification of financial liberalization in East Asia, influenced substantially by the IMF to which many of these countries turned for balance of payments support in the immediate aftermath of the crisis. The resolution of the immediate financial and banking crises, facilitated by the infusion of capital to return financial firms to solvency and provision of guarantees to foreign creditors by governments in the region, combined with this liberalization to restore capital flows to these countries after some lag.

\footnotetext{
${ }^{1}$ That exception was South Korea that had access to private debt markets because of an implicit sovereign guarantee from the US government, which backed South Korea as a frontline nation in the Cold War.
} 


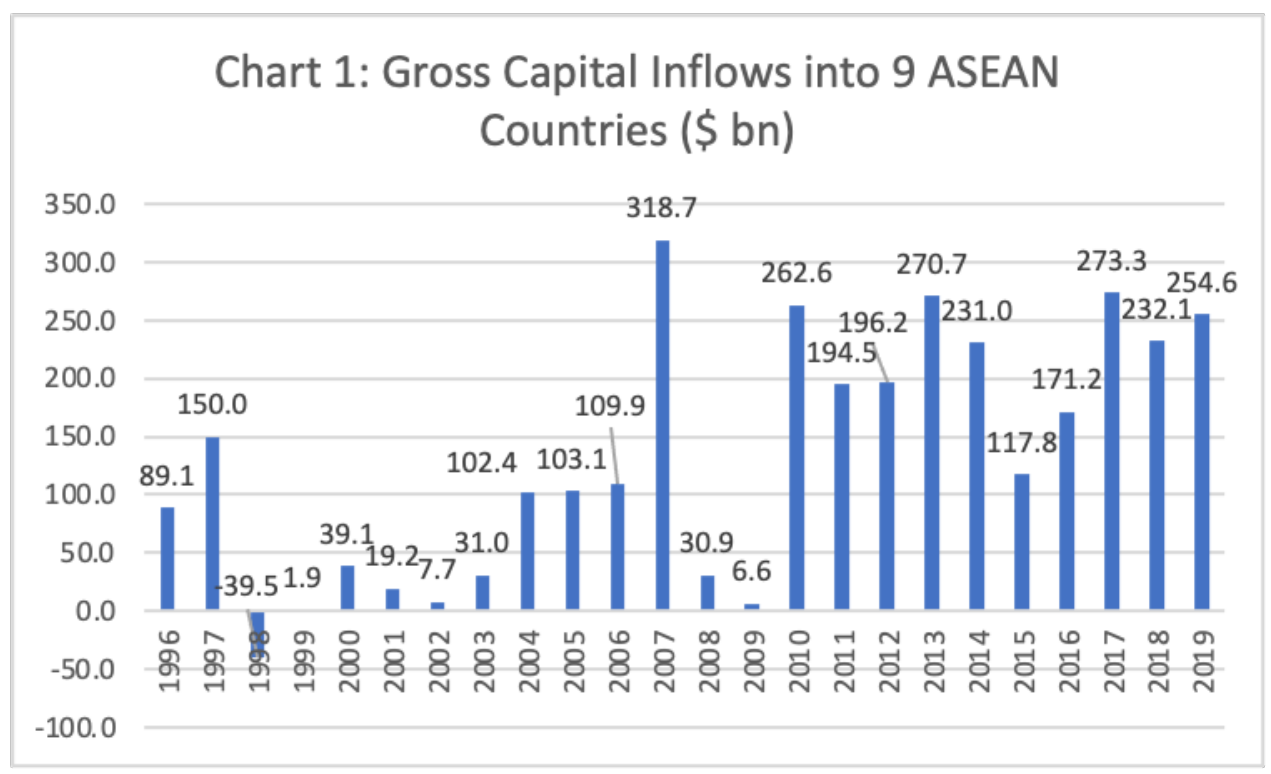

Source: IMF Balance of Payments and International Investment Position Statistics, accessed at https://data.imf.org/?sk=7A51304B-6426-40C0-83DD-CA473CA1FD52.

Chart 1 tracks gross capital flows to 9 of the 10 ASEAN countries ${ }^{2}$ starting the year just before the Southeast Asian financial crisis. From a high of $\$ 150$ billion in 1997, those flows turned negative (became outflows) to the tune of $\$ 49$ billion in 1998 , stood at just under a positive $\$ 2$ billion in 1999 and remained at relatively low levels for the next four years, averaging \$24 billion a year. Capital flows revived in 2004 and averaged a high \$105 billion during 2004-06, before recording a surge to $\$ 319$ billion in 2007 , just prior to the global financial crisis of 200809, when gross inflows fell to just $\$ 31$ billion in 2008 and around $\$ 7$ billion in 2009. Following the strong monetary response to the crisis in the form of "quantitative easing" and near-zero interest rates on the part of developed-country central banks, especially the Federal Reserve,

\footnotetext{
${ }^{2}$ Brunei Darussalam is excluded because of absence of comparable data for the full time period covered. The Financial account in the IMF's Balance of Payments Manual 6 framework covers all transactions associated with changes of ownership in the foreign financial assets and liabilities of an economy. The financial account is broken down into five basic functional categories: Direct investment (divided by instrument into equity and investment fund shares, reinvestment of earnings and debt instruments), Portfolio investment (divided by instrument into equity and investment fund shares, reinvestment of earnings for investment fund shares and debt securities), Financial derivatives and employee stock options, Other investment (divided by instrument into other equity, currency and deposits, loans, insurance, pension schemes and other standardized guarantee schemes, trade credits and advances, other accounts receivable/payable and special drawing rights) and Official reserve assets (divided by instrument into monetary gold, special drawing rights, reserve position in the International Monetary Fund and other reserve assets). Gross capital flow is calculated as the sum of "net incurrence of liabilities" under the head's direct investment, portfolio investment, financial derivatives and other investment. Net capital flow is calculated by subtracting the net incurrence of liabilities under the head's direct investment, portfolio investment, financial derivatives and other investment, from the net acquisition of assets under the same heads (that is excluding net acquisition of reserve assets by the monetary authority). For the financial account items, in BPM6 the headings and signs in the BoP financial account have been changed from "credit" and "debit" to "net acquisition of assets" and "net incurrence of liabilities". The new terminology and sign convention for the BoP financial account are consistent with those for the International Investment Position tables, i.e. a positive sign of net values represent an increase, and a negative sign represents a decrease, in the asset or a liability to which it relates. Thus, for "net acquisition of assets" in the financial account of the BoP, a plus sign denotes a net increase in financial assets, while a minus sign refers to a net decrease in financial assets. The net for each item is calculated as net acquisition of assets - net incurrence of liabilities and may be positive or negative. The net balance on financial account has the opposite sign in BPM6 compared to BPM5 (e.g. a net inflow in the financial account is represented with a minus sign in BPM6, whereas it has a positive sign in BPM5) (Eurostat 2019).
} 
capital flows surged starting 2010, averaging \$231 billion during 2010-14. Then, after a dip in 2015 and 2016 to an average of \$145 billion, they recovered to an average of \$253 billion during 2017-19. Overall, the evidence points to considerable volatility in flows, making the region vulnerable to crises. Seen in that light, the extended surge in capital inflows over 200918 is a matter of concern, pointing to growing balance of payments and financial vulnerability.

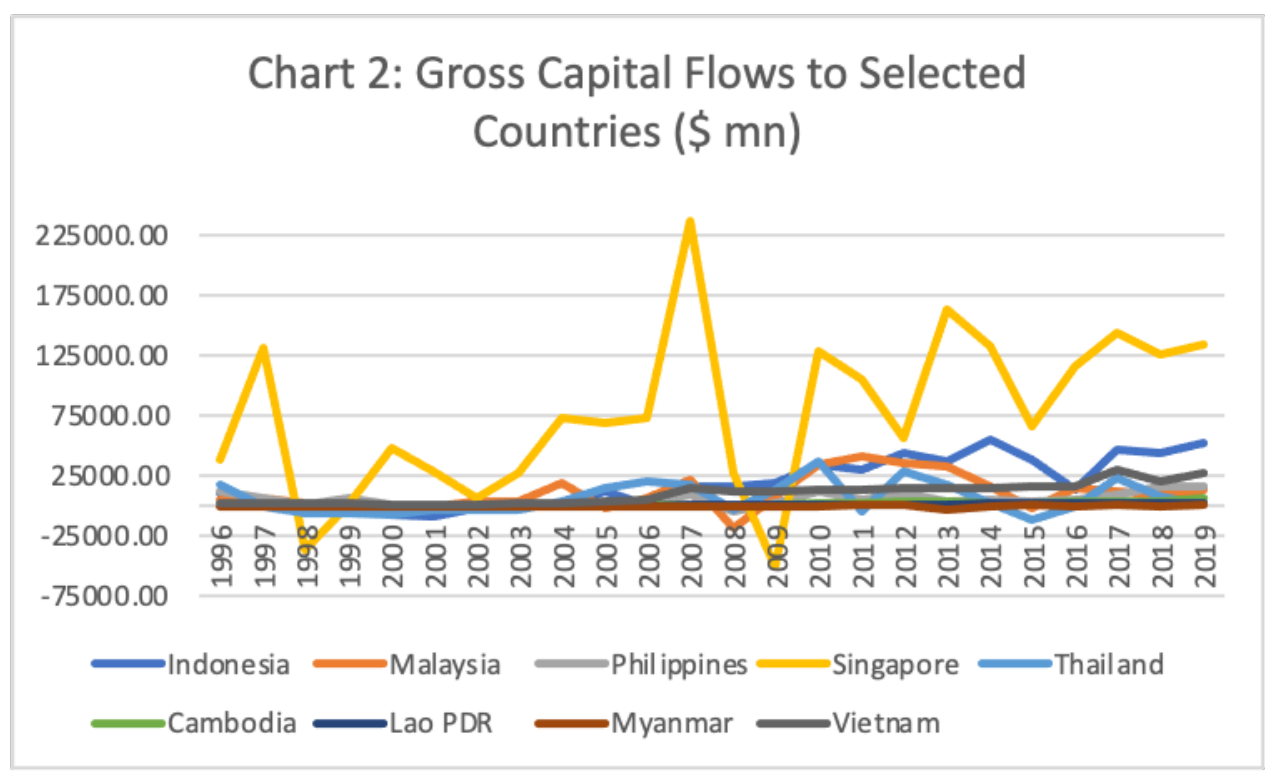

Source: Same as Chart 1.

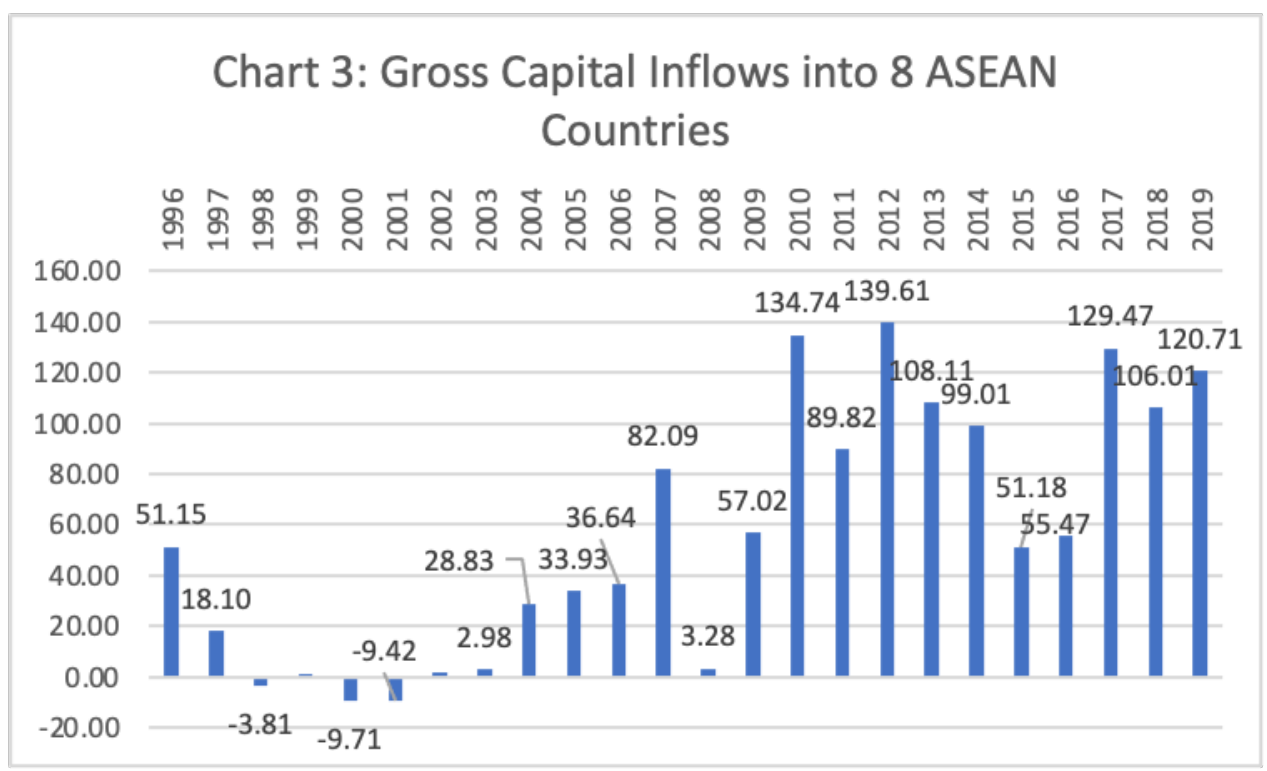

Source: Same as Chart 1.

These trends in the ASEAN-9 have been unduly influenced by flows to Singapore, which serves as a minor regional financial center. Capital flows to Singapore have tended to diverge significantly from those to the rest of ASEAN, being mostly much higher and far more volatile (Chart 2). However, as Chart 3 makes clear, even when Singapore is excluded, the trends are very similar across the 1996-2018 period for the other 8 countries. The vulnerability implicit in those trends appears all the greater when we examine net flow numbers (Chart 4). After the 1997 crisis, net flows to the ASEAN-8 were low or negative for a much longer period stretching from 1998 till the 2008-09 crisis. On the other hand, the surge in inflows starting 2010 was visible in the case of net flows as well, with net inflows averaging \$48 billion during 2010-12. 
But the dip in 2013-15, following the "taper tantrum" of 2013 generated by fears that "quantitative easing" would be withdrawn, was much sharper in the case of net flows, with the figure turning negative in 2015. Once the policy of "quantitative easing" was reaffirmed, net flows to the ASEAN-8 surged again, averaging $\$ 41$ billion over 2016-19. This corroborates the conclusion that capital flows to the region have been characterized by a high degree of volatility.

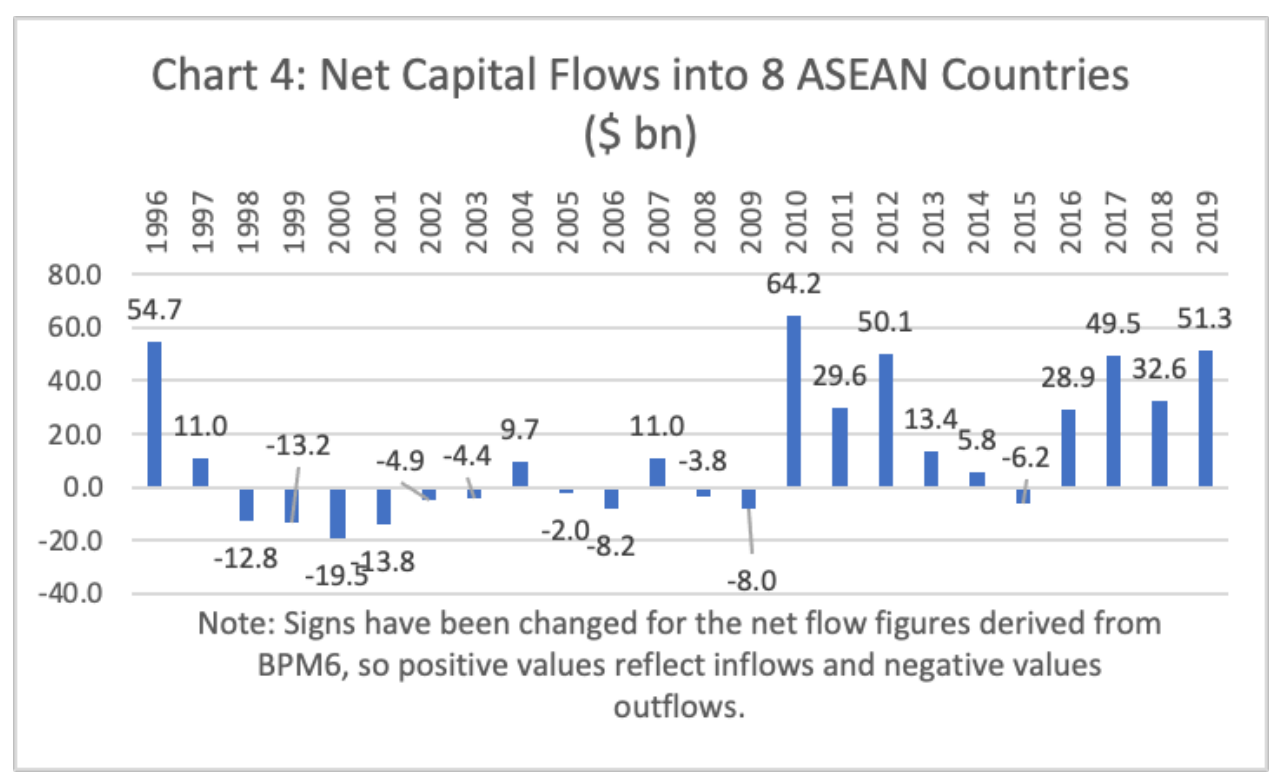

Source: Same as Chart 1.

The persistence of volatility was partly a result of the decision, even after the 1997 crisis, that policy should not seek to control capital inflows, but focus on managing the volatility and vulnerability that openness to such capital flows entails. At the time of the 1997 crisis, three countries - Thailand, Indonesia and the Republic of Korea - that had short-term debt in excess of their reserves and faced a hard currency crunch that could not be alleviated with support from private finance, were forced to turn to the IMF for balance of payments support. However, the conditionality imposed by the IMF proved to be damaging and extremely unpopular. Sussangkarn (2010) summarizes the various criticisms of the IMF programs that were subsequently advanced, which included:

1. Imposing tight fiscal and monetary policies that worsened a bad situation and ignored the social and political consequences they could have, including a change in political regime in Indonesia. ${ }^{3}$

2. Enforcing further liberalization of the financial sector and discouraging capital controls, despite evidence that boom-bust cycles in cross-border flows of capital triggered the crisis.

3. Absolving speculative foreign lenders and financial investors of any responsibility for the crisis and protecting creditors (mostly foreign) of domestic financial institutions with full government guarantees.

\footnotetext{
3 "In Indonesia, the IMF allowed banks to fail without any system of deposit insurance in place, thus triggering a major financial panic. As a result, many banks (that were) not initially in dire straits collapsed, with significant repercussions for the populace, a large proportion of whom were just above the poverty line prior to the onset of crisis." Amyx (2002: 9).
} 
4. Failing to prevent distress sales of assets of private firms and privatization of stateowned enterprises, all at bargain prices that were even lower in dollar terms because of currency depreciation. ${ }^{4}$

Resentment of IMF-style adjustment was thus inevitable.

However, as noted, despite this experience, there was limited support even within the ASEAN countries for a reversal of open-door policies governing cross-border financial flows. Experiencing the consequences of opting for IMF support in response to the crisis, countries in the region turned their attention to identifying regionally implemented, IMF-independent, rapid action measures that could ensure that liquidity flowed easily to countries faced with temporary balance of payments difficulties or that fell victim to boom-bust capital flow cycles, so that they could stabilize themselves. Countries able to extend such liquidity support would also be beneficiaries of a return to stability, as potential contagion effects would be simultaneously dampened and regional deflation resulting from IMF-style, pro-cyclical policies avoided, shielding them from the effects of that crisis.

This case for mutually beneficial intervention led to a range of policy recommendations, central to many of which was a framework of regional cooperation that sought to ensure availability of short term balance of payments financing as well as foreign currency resources needed to support long term investment. However, after more than two decades marked by other crises that affected the region, the results of the efforts to implement those recommendations are underwhelming. The most far reaching of the proposals mooted by Japan at the Fund-Bank meetings in Hong Kong in 1997, to establish an Asian Monetary Fund (AMF), or an IMF equivalent for the Asian region under regional control, failed to take off in the face of US opposition. The framework which was actually implemented was an enhanced version of a regional arrangement involving central bank foreign exchange swaps. That framework was modified multiple times, but all versions remained largely unutilized by member countries. This was not because members did not need support on more than one occasion, even though the demand for such support was short of what was originally expected. In practice, when support was needed, countries preferred to draw on bilateral facilities or those available from institutions and governments outside the region, defeating the very purpose for which a regional arrangement was crafted after the 1997 crisis. When regional arrangements were utilized, these involved bilateral agreements rather than facilities offered as part of the regional cooperation framework.

The Asian experience suggests that the greater reliance on extra-regional financial support facilities and bilateral, as opposed to multilateral, intra-regional facilities, resulted from geopolitical factors. Those factors, specifically the inability of Japan to either exercise leadership over a fully independent regional initiative or win regional support for its leadership role, limited the size and scope of regional arrangements, and prevented those arrangements from being independent of the influence of the US and the IMF, and the kind of policies they backed. This suggests that a financial safety net that is IMF-independent and region-wide in coverage can evolve only if a dominant regional player sets up a network of bilateral arrangements or multilateral arrangements it controls, to serve the purpose. ${ }^{5}$ If any player chooses to do that, it would have to advance substantial resources to back that effort and face up to challenges from the dominant OECD countries aligned with and led by the US, which

\footnotetext{
${ }^{4}$ See also Chandrasekhar and Ghosh (2001).

${ }^{5}$ While this may sound like a regional version of Kindleberger's (1973) idea that the world needs an economic hegemon willing to serve as a market and lender of last resort for the rest, the real emphasis here is on the inability to forge a multilaterally governed and cooperative regional stabilizing mechanism independent of the extra-regional hegemon, given historically determined geopolitical tensions in the region.
} 
currently hegemonize the international financial order and determine the rules that govern it. Any regional arrangement without a dominant player contributing substantial resources is bound to fail, unless the arrangement is one that shuts off volatile capital flows to the region.

For some time, Japan was the one country that could have taken on the task of shaping an independent financial safety net in an Asia open to capital flows. But the experience since 1997 makes clear that Japan is not up to the task. Meanwhile, the geopolitical context in Asia has changed, with China emerging as a regional power with the resources to bid for hegemony and, by all indications, the ambition to become a regional hegemon. The principal change has been a decline in Japan's role and influence, and a significant increase in China's presence in and contribution to adjustment efforts adopted by countries in the region. As of now, it is this development rather than the tweaking of democratically governed regional arrangements that can create, if at all, a regional financial safety net independent of the US and the IMF.

This paper is an attempt to track and explain the trajectory that regional financial arrangements aimed at managing volatility and financing investment have actually taken. A central component of that exercise must be an examination of the reasons for the 'failure' of formal regional financial cooperation efforts aimed at preventing or managing financial crises within the region. There are three key issues that recur in the discussion. The first is the degree to which any cooperation effort is independent of US influence, given the role of the US government in scuppering the AMF initiative. The second is the degree to which forms of financial cooperation reflect undue influence of one or more of the dominant powers in the region, especially Japan and China. The third is the relative role in practice of Japan and China as dominant players in evolving regional financial arrangements.

In discussing these issues, six different but interrelated lines of discussion are pursued. The first is an assessment of the factors that undermined the proposal to establish the AMF in the years following the 1997 Southeast Asian crisis. The second is an exploration of the nature of external vulnerabilities that persisted and intensified after the Southeast Asian crisis. The third is a delineation of the rationale and the likely effectiveness of the cooperation arrangements that were actually adopted in practice. The fourth is a discussion of the factors explaining the failure of the regional cooperation effort. The fifth is an examination of the importance of national, extra-regional and bilateral financial safety net arrangements, and the factors determining their persistence. Finally, China's growing importance and role in driving cross border flows and addressing financial volatility in the region are assessed, in terms of their implications and sustainability.

\section{The abortive effort to establish the AMF}

The discussion on regional financial cooperation gathered momentum after the 1997 financial crisis, when Japan mooted the proposal to establish an Asian Monetary Fund, to be largely independent of the IMF and the US. This was to be a $\$ 100$ billion fund to start with, with Japan contributing half that sum and the rest being provided by foreign exchange surplus countries such as China, Hong Kong and Singapore. ${ }^{6}$ Set up as a financial institution, the organization would have been in a position to leverage this capital to borrow funds in international markets to substantially enlarge its power to intervene when members in the region were faced with dollar or other hard currency shortages. It was to have East Asian states as members, and serve

\footnotetext{
${ }^{6}$ According to one assessment, as compared with the aggregate debt of around $\$ 300$ billion of countries in the region the aggregate surpluses held by the surplus countries was around $\$ 800$ billion, making regional selfreliance in crisis management a possibility. Shaun Narine (2003).
} 
to track external vulnerability, provide emergency finance and monitor performance based on a regional surveillance mechanism. ${ }^{7}$

Japan's decision to propose an AMF was partly driven by its realization after the 1997 crisis that the US was not willing to contribute to support even an IMF-led effort at restructuring Asian debt, saving the lender banks, and ensuring recovery, as it did in Latin America in the 1980s. This mattered, given the exposure of Japan and Japanese banks to Asia. Foreign loans and assets accounted for around 22 per cent of the assets of Japan's 20 largest banks in 1997. Much of the lending was to Southeast Asian nations. Around that time, the Bank for International Settlements (BIS) reported that loans outstanding of Japanese banks to Asian businesses amounted to more than $\$ 275$ billion, and the exposure of Japanese banks to Asia was around six times that of US banks and twice that of German banks (Craig 1998). Data collated by Lipscy (2003) shows that Japanese exposure, at around 25 per cent of its lending to all developing countries, was much higher than that of the EU and the US. In absolute terms, according to this estimate, Japanese financial institutions had lent around $\$ 38$ billion as compared with $\$ 20$ billion in the case of the EU and $\$ 4$ billion for the US.

Moreover, these Asian markets accounted for more than 40 per cent of Japanese exports. So, a crisis in Asia meant a crisis for Japanese banks and its economy. Quick resolution of the crisis was crucial from Japan's point of view. And an IMF-style deflationary response to the crisis would not serve its interests. Eisuke Sakakibara, the then Japanese Deputy Finance Minister, who advanced the AMF proposal, noted in an interview 20 years later, that the proposal was motivated by the view that the IMF "didn't know Asia" and "its remedies were likely to do great damage to the Asian economy" (Iwamoto 2017). ${ }^{8}$

The scale of the crisis was such that conventional IMF packages would have been inadequate. When the Thai baht collapsed in 1997, the flight of capital out of Thailand was of a magnitude that required liquidity infusion far in excess of what that country would normally be eligible for under IMF rules. The rescue package that was put together by the IMF involved substantial funding from Asian nations, particularly Japan. The IMF, on August 20, 1997, approved a stand-by credit line from its resources of SDR 2.9 billion (around $\$ 4$ billion), which amounted to 505 per cent of Thailand's quota of SDR 573.9 million (approximately $\$ 780$ million). Even with that level of IMF funding, the attempt at crisis resolution had to be supported with bilateral commitments of aid. Western countries, including the US, Germany, France and Canada, did not participate. Support came mainly from Japan (\$4 billion), Australia, Hong Kong, Malaysia and Singapore ( $\$ 1$ billion each) and the rest from Indonesia, South Korea, the Asian Development Bank, the World Bank and China (IMF 2000; Pollack 1997). ${ }^{9}$

Since the dollar is the preferred currency in which external transactions are denominated, a payments crisis normally involves a shortage of dollar liquidity. So, it was expected that the US would lead and substantially finance the crisis-resolution effort, restoring the confidence

\footnotetext{
${ }^{7}$ However, even the AMF was presented as a regional supplement to IMF lending and surveillance, pointing to the expectation of US opposition.

${ }^{8}$ Such views were held and continued to be expressed by other leaders in the region. Speaking at the "Future of Asia" Conference organized by the Nihon Keizai Shimbun in May 2005, Thailand's minister of finance Thanong Bidaya said: "The US responded passively to the Asian Crisis, compared to the speed and effort with which it had responded to the Mexican Crisis. In addition, the IMF conditionality was not appropriate to the crisisaffected countries because of the lack of true understanding of the situation and underlying economic condition." Quoted in Grimes (2009: $4 \mathrm{fn}$ 2).

${ }^{9}$ Overall, "Some $\$ 35$ billion of IMF financial support was provided for adjustment and reform programs in Indonesia, Korea, and Thailand, with the assistance for Indonesia being augmented further in 1998-99. Some $\$ 85$ billion of financing was committed from other multilateral and bilateral sources, although not all of this financing actually materialized." IMF (2000).
} 
of private lenders and investors (Amyx 2002). That is what it did at the time of the Mexican peso crisis of 1994, which resulted in large part from profligate borrowing by the government. In 1995, as the peso collapsed and the Mexican economy contracted, President Bill Clinton and a Treasury Department team including Treasury secretary Robert Rubin and Undersecretary Lawrence Summers intervened to put together a large-scale bailout package for Mexico. The thrust of that effort was to ensure a line of credit to Mexico large enough to counter the speculative attack that threatened to further drive down the peso and the Mexican economy. The bailout credit line of around $\$ 50$ billion was made possible by a $\$ 20$ billion contribution from the U.S. Treasury, which persuaded others to chip in: the IMF with $\$ 18$ billion, the Bank for International Settlements with $\$ 10$ billion, and private banks with a much smaller $\$ 3$ billion or so. As part of the deal, the Mexican government had to accept placing future oil revenues in an escrow account at the Federal Reserve in New York to ensure that all loans owed would be repaid at face value with the commercial banks not taking any haircuts. Mexico had to also accept IMF-style austerity as part of the stabilization and adjustment package. Creditors avoided the losses that would have been the penalty for their speculative lending, capital flows to Mexico resumed in time, but ordinary citizens had to pay with loss of jobs and livelihoods.

When the crisis broke in Southeast Asia, on the other hand, no such contribution from the US Treasury was forthcoming. The crisis in most Asian countries was not the result of government profligacy, but of excess lending by international banks and borrowing by the domestic private sector. The macroeconomic stance of many Southeast Asian governments had been conservative, with many budgets recording surpluses. Yet governments were forced to adopt austerity measures, take over or guarantee loans received from the international banking system, and further liberalize financial policy and open up the financial sector. In return, bail out packages financed largely by Japan and the IMF were provided.

Ferguson (2001) attributes the specific and discriminatory treatment meted out by the US government and the IMF to the East Asian countries, when compared with Mexico, to the domestic political strategy of an increasing unpopular Clinton administration which was preparing to make a bid for a second term in office at the time of the Asian crisis. In the Mexican case it was not only the commercial banks but institutions such as pension and mutual funds and investment banks that were exposed, making it difficult to institute debt rescheduling negotiations to avoid default. In that context, the US, with the IMF's support, arranged the money needed to bail out the institutional investors.

In Southeast Asia, it was the commercial banks that were the principal providers of loans from abroad. Yet, here too, the road taken was not one of letting the banks negotiate to reschedule these debts, with or without haircuts. Instead, to please Wall Street, which Clinton was wooing for political and financial support, the US (even as it held back on contributing to a bail out) pushed for major liberalization and restructuring of the financial sector. In Ferguson's words: "the Treasury and the IMF sought to institutionalize Anglo-Saxon-style financial capitalism in Asia all at once. In place of the usual closed circle of state-encouraged, "national champion" firms borrowing vast amounts of money from government-controlled savings systems at concessionary rates, the Treasury sought the creation, virtually overnight, of American-style "transparent" markets for stocks and bonds." The objective was "to open up to Wall Street the pension funds and other savings vehicles of what had been the fastest-growing and highestsaving countries in the world, and to create lucrative new markets for services that are the stock in trade of the investment houses: securities placement, privatization, mergers, and acquisitions." (Ferguson 2001: p. 233).

This outcome favoring US finance was paradoxical, since the US government seemed unwilling to finance a rescue effort for Thailand and other Southeast countries in crisis. Japan 
had to take up a leadership role in the matter. Official US indifference and Japan's leadership explained Japan's case for an AMF, since voluntary Japanese government initiatives in response to individual crises may not be the best way to go in a world where cross-border capital flows were large and rising. An institutional framework seemed warranted. The absence of US interest in taking on a role similar to that it played in Latin America seemed to justify the case for creating an AMF without US membership. But the US government's agenda of instituting an Anglo-Saxon type financial environment, by exploiting the financial vulnerability that the crisis intensified, led to US opposition to the Asian Monetary Fund. If countries in the East Asian region came together to establish an institution that did not rely on US and IMF support and rejected IMF-style stabilization and adjustment, Anglo-Saxon finance could be kept out of this most dynamic and lucrative of financial markets. Sakakibara corroborates the view that the idea of an AMF had to be shelved, even though it appeared that South Korea and the ASEAN countries were in its favor, because of opposition from both the IMF and the US. The US and the IMF feared they would lose financial and economic influence in the region, and that the emergence of an AMF would challenge IMF-type policy prescriptions which favored US finance. ${ }^{10}$

\section{The retreat}

Other features characterizing geopolitics in the region combined with US and IMF opposition to quickly stall any progress of the AMF idea. Overall, three factors worked to undermine the proposal. The first was the subordinate position Japan held in its special bilateral relationship with the US. The second was the fear of Japanese dominance among other countries in the region, influenced not just by its economic strength, but by the history of Japanese colonialism in the region - a fear which the US is seen as having exploited, especially vis-a-vis China. ${ }^{11}$ Third, the dependence of many ASEAN countries on US markets and US-mediated capital flows, which resulted in these countries softening their stance once the US and the IMF expressed their opposition to the AMF. However, at the Hong Kong meeting, ASEAN members and South Korea did support the AMF proposal, while the hosts and Australia remained neutral. Even so, Japan decided to hold back and withdraw the proposal. After the initial bid for greater regional influence mediated by an institution independent of the US and the IMF, Japan quickly withdrew.

This reflected the nature of Japan's integration with the rest of the world, which precluded resilience in the face of US opposition. Defeat in the Second World War and the terms of Japanese surrender meant that Japan had officially accepted a politically and militarily subordinate and dependent relationship with the United States. In addition, the post-War Japanese boom was fueled in substantial measure by exports to the United States. Even after the Plaza Accord of 1985, through which the US ensured a huge appreciation of the yen vis-àvis the dollar and undermined the competitiveness of Japan as a location for export production,

\footnotetext{
${ }^{10}$ The official reasons reportedly quoted by the US for its opposition were moral hazard and duplication of the IMF's role (Lipscy 2003). It has been (speculatively) argued that the US was also worried that Asian states and private banks that were major investors in US Treasury bills, would divert their resources to finance a regional mechanism. If banks in the region, led by the Bank of Japan, sold Treasuries to finance the AMF, US interest rates could spike, adversely affecting an ongoing US economic recovery. See Nordhaug (2000).

11 "History remains the single greatest factor overshadowing Japan's relations with East Asia. The general perception in Asia is that Japan has never adequately apologized for the atrocities it committed against other Asian nations during its imperial period (1895-1945) and has never accepted responsibility for its actions. These views are particularly strongly held in China, which suffered the most under Japanese aggression." Narine (2003: 84). China's opposition has also been attributed to it being unaffected by the 1997 crisis, given its then closed financial system, and to the fact that it was then engaged in late-stage negotiations for accession to the WTO and, hence, did not want to alienate the US. See for example Amyx (2005).
} 
Japanese firms remained dependent on the US market as part of the Asian export platform. With their competitiveness undermined by the Plaza Accord, Japanese firms relocated to East Asia. In the early 2000s, for example, East Asia was home to 40 per cent of a total of around 19,000 Japanese overseas subsidiaries which accounted for around 16-20 per cent of Japanese FDI flows (Farrell and Pangetsu 2007). Having started in the newly industrializing countries (NIEs, consisting of South Korea, Taiwan and Hong Kong), investment shifted to the ASEAN countries and then China. For these countries too, the US market was crucial. Over the years 1996 to 2001, 30 per cent of Japanese exports and 20 per cent of exports from developing and emerging Asia were directed to the US. Maintaining a good relationship with the US was crucial for the region. So, Japan (and the export dependent ASEAN economies) could not alienate the US by ignoring its opposition.

\section{Intra-Asian conflict}

It did not help that there was also apprehension among Asian countries about any increase in Japanese regional influence that could result from the AMF. Not only was Japan the dominant economy in the region, but it also had a long history as a colonial ruler starting with the SinoJapanese War of 1894-95 to the end of the Second World War. In the Asian region, Korea and Taiwan were formal colonies of Japan and regions of China were informally colonized for a considerable period of time. Despite Japanese efforts to underplay colonial repression, discussions of the Nanjing massacre, forced labor, and sexual slavery ("comfort women") recur in South Korea and China. Given the absence of historical reconciliation, the fact that the idea of the AMF emanated from Japan, which would dominate the proposed organization, must have aroused fears and suspicions, even if these were not publicly articulated.

That, together with the growing rivalry between China and Japan for supremacy in the region, also explains China's ambivalence. Even while recognizing the malevolent influence of the US after the Second World War, the Chinese perception was that the Japanese initiative would increase the latter's influence in the Asian region with adverse geopolitical implications. ${ }^{12}$ Put together, these aspects of the region's political economy resulted in the success of the US effort to thwart the AMF initiative. ${ }^{13}$

\section{The Miyazawa Initiative}

Having failed in its effort to put in place the AMF, Japanese economic diplomacy focused on bilateral assistance to individual countries, as contagion carried the crisis to Indonesia in October 1997 and other nations in the region soon thereafter. ${ }^{14}$ Representative of that push was the New Miyazawa Initiative.

Announced in October 1998 by Finance Minister Miyazawa Kiichi, the Miyazawa Initiative was a $\$ 30$ billion package to support economic recovery in East Asian countries affected by the crisis, by providing financial assistance on a bilateral basis, as well as funding a facility at the Asian Development Bank (\$3 billion) to guarantee bonds issued in international financial markets. The success of the initiative was reflected in substantial use of the assistance on offer. East Asian countries that availed financial assistance under the initiative included Thailand in December 1998 ( $\$ 1.9$ billion); Malaysia in December 1998 and in March 1999 (\$2.2 billion); Indonesia in February 1999 (\$2.4 billion); the Philippines in March 1999 (\$1.6 billion) and

\footnotetext{
12 Japan's subordinate relationship with the US affected it in two ways. It could not stand up to US pressure on the AMF. It was also viewed suspiciously by countries in the region, China especially, as a front for US hegemonic intentions.

${ }^{13}$ Grimes (2009: 41), on the other hand, sees this regional political fragmentation as being "largely the legacy of European colonialism, the Pacific War, and the Cold War."

${ }^{14}$ For a favorable interpretation of Japan's economic diplomacy see, Hook et al (2002).
} 
South Korea in January and March 1999 (\$6 billion). This support was in addition to Japan's contribution to the IMF-led bailouts in the region, the $\$ 22.5$ billion in export credits to promote intra-regional exports and other Official Development Assistance (Hook et al 2002).

To an extent, support through the Miyazawa Initiative was an alternative to conditionality-tied borrowing from the IMF. While funds through the initiative were only supplementary in countries that had entered into an agreement with the IMF, in countries like Malaysia, Vietnam and Myanmar that had not accepted or were not provided IMF support, they served as an alternative. This mattered for Malaysia in particular, which had rejected IMF support because it involved further opening and austerity and had opted instead for capital controls. According to Amyx (2002: 11): "A prerequisite for the receipt of support through the New Miyazawa Initiative was simply "economic reform, taking into account the situation in each country'."15 Clearly, creating a crisis resolution mechanism independent of the IMF and the US was possible, if a regionally dominant power like Japan chose to build such a mechanism using bilateral arrangements and agreement with multiple countries and institutions (such as the ADB).

The Miyazawa Initiative also experimented with currency swap arrangements. It extended the forms of support available beyond loans and credit guarantees, to include currency swap arrangements between central banks, which were taken up by the central banks of South Korea and Malaysia. ${ }^{16}$ The resort to currency swaps was the first effort to go beyond immediate aid to address the crisis and put in place mechanisms that could help countries avoid or prevent a currency crisis.

Under a foreign exchange swap arrangement, the central banks concerned provided for the exchange on request of designated amounts of two different currencies with the agreement that the exchange would be reversed at a specified future date on predetermined terms that include an interest rate being paid by one party to another. In fact, as we discuss below, subsequently, swaps became the principal element of regional cooperation fashioned in response to the Southeast Asian financial crisis.

However, as noted earlier, in the absence of an institutional arrangement that could mobilize resources from financial markets, Japan's direct contribution was restricted to crisis resolution rather than evolving a mechanism for crisis prediction and prevention. Moreover, there was no guarantee that in the event of more such crises in a world of increased cross-border capital flows, Japan would be willing, even if able, to mount a similar effort equal to the task at hand. After all, in the late 1980s Japan had experienced its own financial crisis followed by a recession and years of stagnation, from which it has barely recovered even today. In practice, the Miyazawa Initiative became a short term response to the crisis, rather than the launch of a network of bilateral mechanisms under Japanese aegis that could provide an enduring financial safety net for countries in the region.

\section{A turn to regional cooperation}

\footnotetext{
${ }^{15}$ Eisuke Sakakibara reportedly said that though Malaysia was subject to international criticism because of the capital controls it imposed in September 1998, which hurt US and European financial institutions, since "Malaysia, ..., was important to Japan and Tokyo was not necessarily opposed to the control on capital outflows to avert a crisis," it was "unthinkable to exclude Malaysia" from the New Miyazawa plan. Quoted in Grimes (1999: 79).

${ }^{16}$ Bilateral swap arrangements under the New Miyazawa Initiative included one between Malaysia and Japan (to the tune of US\$2.5 billion) and another between South Korea and Japan (of US\$5 billion). Amyx (2002: 14$15)$.
} 
Possibly, this experience with Japanese support and the fear of a likely power imbalance in the region favoring Japan, led to the search for a regional financial cooperation framework that would not give Japan disproportionate influence and emphasized regional self-help in times of crisis. That search led initially to a Cooperative Financing Arrangement (CFA), or an understanding among East Asian countries that each would assist others when hit by crisis. ${ }^{17}$ Help was to be provided through the establishment of currency swap arrangements between central banks, through which countries facing balance of payments difficulties and unable to meet dollar or "hard currency" payments commitments could exchange their local currencies for suitable alternative currencies to be deployed for short periods of time to tide over their difficulties.

Foreign exchange swap arrangements between central banks have been in vogue for a while, to facilitate macroeconomic management and finance unexpected foreign exchange payment commitments, augment foreign reserves, manage fluctuations in currency values or stabilize domestic financial markets (Hooyman 1993). In the post-crisis scenario in Southeast Asia, swaps had to help central banks support domestic agents facing foreign funding shortages to meet payments commitments of different kinds or use the facility to finance open market intervention to stabilize a depreciating currency.

In practice, a swap arrangement can serve as a means of dealing with balance of payments difficulties only if it primarily makes available dollar liquidity. Given the dollar's role as the world's principal reserve currency for around three-quarters of a century, trade and crossborder financial transactions were and are overwhelmingly denominated in dollars, ${ }^{18}$ necessitating constant access to dollar liquidity for countries other than the US. Meeting that demand through a cooperation arrangement that does not include the US would require countries participating in the arrangement to possess and be willing to share surplus dollar reserves when any member is faced with a shortage of dollar liquidity.

In cases where bilateral trade links are strong and regional currency financial flows substantial, swaps of other currencies like the yen or yuan can also help, in supporting bilateral transactions. These currencies can also be exchanged for dollars, though there are exchange risks involved. But when dollar funding markets are strained in crisis situations, what is required is direct access to dollars, which must come from the reserves that swap partners have and are willing to release. ${ }^{19}$

The Chiang Mai Initiative (CMI), which defined the form of Asian regional cooperation to address the external vulnerability revealed by the 1997 crisis, involved such commitments on the part of member countries. The CMI was principally a set of currency swap arrangements,

\footnotetext{
${ }^{17}$ Given the experience with the Thailand case, the CFA appeared to be a means of facilitating the mobilization of adequate resources in excess of that provided by the IMF at a pace fast enough to support countries hit by a crisis.

${ }^{18}$ Based on a sample of 43 countries accounting for 55 per cent of world imports and 57 per cent of world exports, Gopinath (2015) estimated that the dollar's share as an invoicing currency was 4.7 times its share in world imports and 3.1 times its share in world exports. Other estimates such as those by Goldberg and Tille (2008) also speak of around 50 per cent of global trade being transacted in dollars.

${ }^{19}$ As Hyun and Paradise (2019: 10) note: "It is true that the Japanese yen is internationalized to a certain extent and the Chinese renminbi is not fully convertible to other major international currencies such as the USD or Euro, but being able to borrow in yen or renminbi does not carry the same meaning as borrowing in USD. This means that FX reserves using yen or renminbi may be helpful only when the USD-based BSAs (bilateral swap arrangements) within the CMIM cannot take place and that the most preferred and helpful BSAs in the region are still those that are USD-based. This situation drives ASEAN+3 member countries to hoard more FX reserves as a measure of self-insurance against another financial crisis than ESM member countries do."
} 
and in its original form was substantially bilateral in nature, based as it was on a network of bilateral foreign exchange swap arrangements. This in itself need not matter. The CMI would have served its purpose if it satisfied the needs of a regional crisis prevention and resolution framework. These were that it should be: (i) adequate to the task in terms of the volume of resources available; (ii) independent of US influence and IMF-style conditionality; and (iii) based on a framework that sidesteps regional tensions that could undermine the effort. If the arrangement failed to meet all three of these criteria, then it was unlikely to serve as an alternative to IMF support or bilateral support from countries outside the region with dollar surpluses, especially the US.

\section{US as swap leader}

With central bank swaps seeking primarily to address shortages in dollar liquidity, it is not surprising that the US Federal Reserve that is the original source of the principal reserve currency has led the way in establishing and deploying swap arrangements. This has helped non-US central banks that have been provided the facility to access dollar funding at short notice. They can use those funds directly or lend them to financial institutions in their jurisdictions in need of dollar funding. The Fed has had temporary and standing swap arrangements with chosen foreign central banks for many decades now. It has also deployed them effectively whenever money markets have frozen, creating dollar funding shortages for those needing to access dollar resources or roll over existing dollar debt used to finance dollardenominated investments.

A swap operation between the Fed and a foreign central bank involves two transactions: one is the sale to the Fed of a specified volume of the domestic currency of the applicant for dollars at the prevailing market (spot) exchange rate; and the second is a buyback on a prespecified date in the future of the domestic currency with dollars by the foreign central bank, at the same exchange rate. When the second transaction is completed the foreign central bank also pays interest at a market-related rate, depending on the duration for which it has drawn on the swap line..$^{20}$

In its earlier history, the Fed used its swap arrangements to intervene in currency markets and manage the dollar's exchange rate, especially with the end of the Bretton Woods arrangement in $1971 .{ }^{21}$ Overall, between the 1960s and the late 1990s the Fed relied on reciprocal swap arrangements either for its own foreign exchange market intervention to stabilize the dollar, or to facilitate intervention by central banks of countries that had accumulated large dollar

\footnotetext{
${ }^{20}$ In principle there is no exchange rate risk because both transactions take place at the spot rate, unless the partner central bank defaults and the value of its currency has depreciated. In that event, the Fed would be left with collateral whose dollar value is lower than the principal that was lent by it. In a foreign exchange swap between two parties other than central banks, designated sums would be exchanged at the spot rate (S) and the (say, foreign) borrowing bank seeking to hedge a domestic currency denominated asset would repay the loaned sum in the currency of the (domestic) lending bank at a pre-agreed forward rate $(\mathrm{F})$. The return to the lender is reflected in the difference between the forward and the spot rate, F-S. If that difference equals the relevant interest rate differential in the two currencies, i.e., $S^{*}\left(1+\mathrm{i}^{\mathrm{d}}\right)=\mathrm{F}^{*}\left(1+\mathrm{i}^{\mathrm{f}}\right)$, where $\mathrm{i}^{\mathrm{d}}$ is the interest rate in the domestic currency, $\mathrm{i}^{\mathrm{f}}$ is the interest rate in the foreign currency (say dollars), $\mathrm{S}$ is the spot exchange rate (domestic currency per unit of foreign currency), and $\mathrm{F}$ is the forward exchange rate, then Covered Interest Rate Parity holds. If it does not, and, say, $F-S=S^{*}\left\{\left[\left(1+\mathrm{i}^{\mathrm{d}}\right) /\left(1+\mathrm{i}^{\mathrm{f}}\right)\right]-1\right\}$ is positive the party lending the domestic currency sells the foreign currency forward at a higher price than warranted by the interest differential. The party borrowing the domestic currency via the swap is implicitly paying a higher interest rate on the swapped dollars.

${ }^{21}$ For a brief history of the Fed's use of swap lines refer Bordo, Humpage and Schwarz (2014). In the early history of swaps, some central banks also used foreign exchange swaps as a means of affecting domestic liquidity (Hooyman 1993).
} 
reserves to protect the value of their unwanted or surplus dollar reserves and not demand that they be exchanged for the Fed's gold stocks. In later years this was dropped, as the US and partner countries preferred to acquire and hold reserves of different currencies to manage the value of their own currencies vis-à-vis those of their economic partners. Most of these swap lines were phased out in 1998, excepting for limited lines with central banks of NAFTA members Canada and Mexico.

\section{Swaps to stabilize financial markets}

After the decline in the Fed's reliance on swaps for foreign exchange market intervention, the return of swaps as instruments used by central banks was triggered by growing instability and crises in financial markets. Such instability saw the emergence of a new role for swap arrangements, concentrated in periods when financial markets faced difficult times. Swaps were now seen as liquidity facilities, making available dollar liquidity on demand to a central bank seeking to support banks falling in its jurisdiction and their clients that were faced with crises-induced dollar funding shortages in regular markets. ${ }^{22}$ Such strains have only intensified after financial liberalization and globalization, which enhanced the presence of foreign investors in financial markets in developed and emerging markets, with most transactions denominated in dollars. Financial liberalization also resulted in a sharp increase in dollar credit to non-bank borrowers. If investors and/or lenders choose to pull out, dollar availability reduces, and financial markets face disarray. In sum, the Fed is creating new and additional dollar liquidity and playing the role of lender of last resort, mediated by the recipient-country central bank whose function is being partly taken over. As compared with this, any effort by the recipient-country's central bank or commercial banks to access dollar liquidity from the market would not result in an expansion of dollar liquidity. Importantly, new generation swap lines are not targeted at addressing current account imbalances, as IMF stabilize and structural adjustment loans are (Bahaj and Reis 2018).

Moreover, an aspect of the trend of financial globalization was the acquisition by non-US banks in developed countries of dollar-denominated assets, financed with dollars borrowed in shortterm markets or through swaps of funds borrowed in domestic currency markets. ${ }^{23}$ The maturity mismatches that often characterized these transactions required the dollar funds to be rolled over. If dollar market conditions disrupted such roll-overs, distress sales of dollardenominated assets that adversely affect financial markets, including in the US, could occur. This was partly what happened in 2007.

Thus, when the Fed, as the source of the principal reserve currency, intervenes to provide liquidity to dollar short entities through their central banks, it plays the role of the lender of last resort outside its jurisdiction, providing foreign central banks and institutions they oversee access to dollars at rates charged at its discount window to US banks and institutions. However, as argued by Bahaj and Reis (2018), unlike when it lends to banks in the US, the Fed does not carry the credit risk, is not forced to often accept weak collateral, and does not expose itself to the moral hazard associated with such lending. The credit risk, the choice of collateral and the moral hazard exposure on such lending falls on the foreign central bank, and the Federal

\footnotetext{
${ }^{22}$ When swap facilities were activated during the Covid-induced economic crisis, the Fed stated its objective as being that of helping "lessen strains in global U.S. dollar funding markets, thereby mitigating the effects of these strains on the supply of credit to households and businesses, both domestically and abroad." https://www .federalreserve.gov/newsevents/pressreleases/monetary20200319b.htm.

${ }^{23} \mathrm{McGuire}$ and von Peter (2009) report that the estimated dollar-denominated positions of European banks accounted for more than half of the overall increase in their foreign assets between end-2000 and mind-2007. The on-balance-sheet dollar exposures of euro area, United Kingdom, and Swiss banks were estimated to exceed $\$ 8$ trillion in 2008 , of which $\$ 1.1$ trillion to $\$ 1.3$ trillion was funded through short-term sources (Goldberg, Kennedy and Miu 2011).
} 
Reserve does not enter as a party in any form in those subsequent transactions. In addition, the Federal Reserve is not faced with any foreign exchange risk on the capital provided since the sale and repurchase of the foreign currency to and from the Fed is at the same exchange rate, and the likelihood of default is negligible. More importantly, swap lines at low interest rates encourage flow of investments from the partner country to the US to acquire assets in the swap source country, preventing a slide in prices of source-country financial assets, besides helping prevent financial crises in the recipient country.

There are a number of noteworthy features of the history of Federal Reserve swap arrangements since around the 1990s. To start with, though such arrangements have been in place for long periods and have even been converted in some cases into standing arrangements, the use of these swaps has been concentrated in periods of crisis. Swaps were deployed after the September 2001 terror attack, when the Fed set up swap lines worth $\$ 90$ billion each against the respective local currencies with the Bank of Canada, the Bank of England, and the ECB, though they were short term and all expired in 30 days. ${ }^{24}$

Since then, as Chart 5 shows, the use of swaps was largely restricted to periods of crisis or uncertainty. The Fed responding to dollar liquidity shortages in the European interbank lending markets aggressively deployed its swap instrument during the global financial crisis of 2007$08 .{ }^{25}$ Starting with the ECB at the end of 2007, arrangements with 13 central banks were established by October 2008. This included a set of emerging markets: Brazil, Singapore and South Korea for the first time, and Mexico, which already had access to a swap line given its close relationship with the US. Initially designed to run for six months, these arrangements were renewed and their term extended till February 1, 2010. Meanwhile, in October 2008, the ceilings on swap facilities available to the Bank of England, the Bank of Japan, the ECB and the SNB were lifted, and they could meet the dollar liquidity of banks in their jurisdiction in full. At its peak, in the week ending December 10, 2008, the use of these swap lines by central banks other than the Fed took the sum outstanding to more than $\$ 580$ billion, or around 25 percent of the Fed's total assets. ${ }^{26}$ It must be noted that even when Fed swaps are not utilized and central banks with access to Fed swaps choose to draw down their own reserves instead, the swap facility matters as a signal to markets of availability of additional reserves.

The Fed also chose to rely on this instrument in 2020 when the Covid-induced crisis overwhelmed both the real economy and financial markets world over. In the US, the crisis adversely affected dollar funding obtained through commercial paper $(\mathrm{CP})$ and certificate of deposit (CD) markets. The flight to cash and safety saw redemptions (of around $\$ 200$ billion till end-March) of investment in prime money market funds (MMFs), which reduced purchases of unsecured short-term CPs issued by banks and non-financial corporations and unsecured CDs issued by banks, and large inflows (of more than $\$ 800$ billion, or about 30 per cent of their assets under management by mid-March) into MMFs that invested in safe government and Treasury instruments. Concomitantly, US dollar LIBOR-OIS (overnight indexed swap) spreads widened. The risk of a run on prime funds was addressed only after 18 March 2020, with the establishment of the Fed Money Market Mutual Fund Liquidity Facility, when LIBOR-OIS spreads also began to decline (Eren, Schrimpf and Shusko 2020).

\footnotetext{
${ }^{24}$ See Fleming and Klagge (2010) and Reis and Bahaj (2018).

${ }^{25}$ U.S. branches of foreign banks were directly supported with credit from the Fed, but many foreign banks did not have access to this window.

${ }^{26}$ For details on the stages in which the facilities were expanded and modified see Fleming and Klagge (2010).
} 


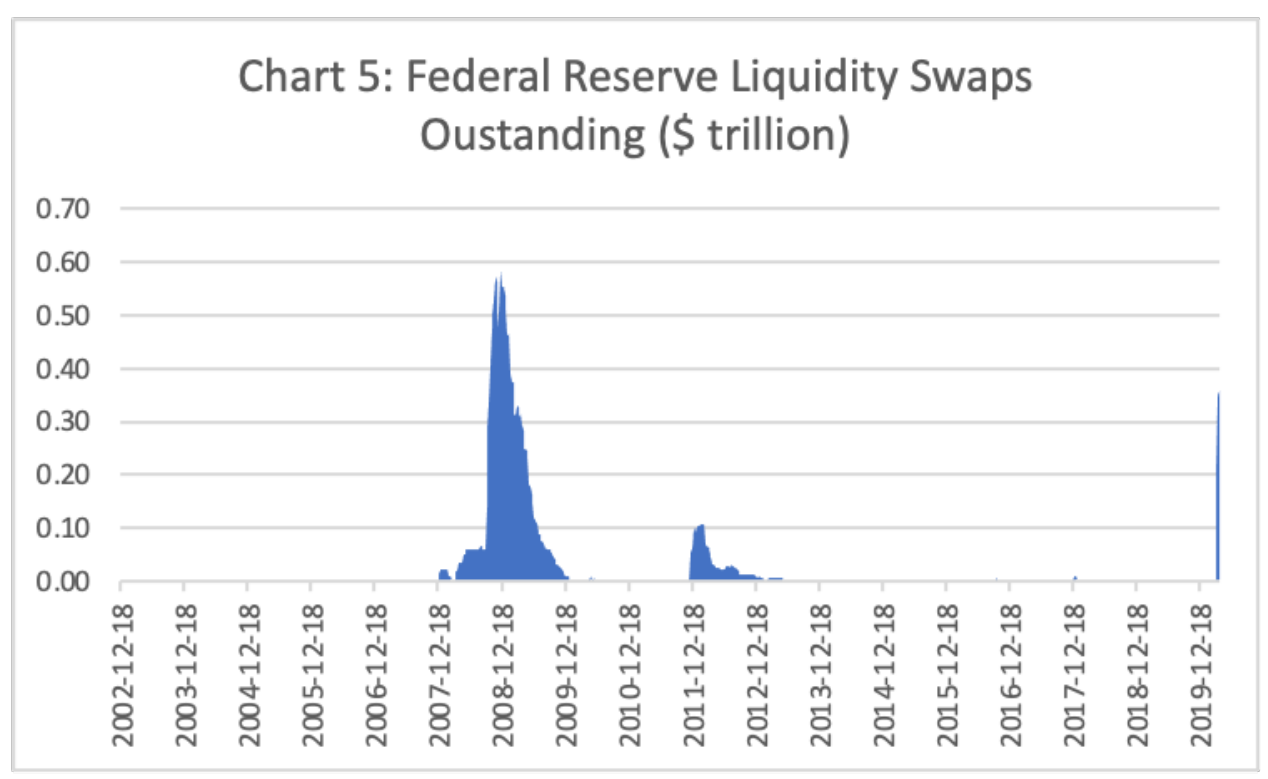

Source: Federal Reserve Bank of New York at https://apps.newyorkfed.org/markets/autorates/fxswaps-search-resultpage?SHOWMORE=TRUE.

Outside the US, banks without access to retail dollar deposits are even more reliant on $\mathrm{CP} / \mathrm{CD}$ based funding. The disruption of the market for these instruments resulted in dollar funding shortages, reflected in wide movements in non-US dollar funding costs such as the crosscurrency basis. ${ }^{27}$ In developing countries this was exacerbated by two factors. One was the exit of financial capital. Capital flight from emerging-market assets was estimated by the Institute of International Finance at $\$ 83$ billion in March 2020 alone. ${ }^{28}$ Between January and March that year, the outflow totaled around $\$ 96$ billion, as compared to the $\$ 26$ billion outflow during the financial crisis of 2008. The second was the demand for dollars from corporates across the world to service the dollar debt they had accumulated during the years of cheap and easy dollar liquidity that followed the 2008 crisis. Dollar debt of non-bank institutions outside the US was estimated at around \$12.6 trillion by the Bank of International Settlements in June 2020, up from around $\$ 6.1$ trillion at the end of $2009 .{ }^{29}$ Dollar liquidity was therefore crucial to manage currencies and support financial markets.

In response to the shortage of dollar liquidity, the Fed, besides improving the terms of its permanent facilities (with the Bank of Canada, Bank of England, Bank of Japan, European Central Bank and Swiss National Bank) extended on March 19, 2020, provided new US dollar swap lines to the central banks of Australia, Brazil, Denmark, Korea, Mexico, Norway, New Zealand, Singapore and Sweden. Countries which, with a lag, managed this crisis were those with access to Federal Reserve swap lines, whose central banks offered dollar liquidity though dollar auctions. By early May, close to $\$ 450$ billion of the Fed's swap lines had been taken up.

\footnotetext{
27 "The cross-currency basis indicates the amount by which the interest paid to borrow one currency by swapping it against another differs from the cost of directly borrowing this currency in the cash market. Thus, a non-zero cross-currency basis indicates a violation of CIP. Since 2007, the basis for lending US dollars against most currencies, notably the euro and yen, has been negative: borrowing dollars through the FX swap market became more expensive than direct funding in the dollar cash market." Borio et al (2016: 45)

${ }^{28}$ Institute of International Finance (2020), IIF Capital Flows Tracker: The Covid-19 Cliff, April, Washington DC: IIF.

${ }^{29}$ Data from BIS Global Liquidity Indicators Table E2 accessed at https://stats.bis.org/statx/srs/table/e2?m=USD\&p=20094\&c=.
} 
Not surprisingly, dollar funding costs in these jurisdictions fell, while they remained high in countries without direct access to the Fed's swap facility (Eren, Schrimpf and Sushko 2020).

A second noteworthy feature of Fed swaps is that the access to these swaps tends to cap deviations from Covered Interest Rate Parity (CIRP) in regular financial markets, improving the terms at which banks can obtain dollar funding from financial markets, rather than from the discount windows of the central bank in their jurisdictions. Banks in countries outside the US facing difficulty borrowing dollars in the interbank market have, in principle, the option of accessing dollar funding by borrowing local currency and entering into a foreign exchange swap for dollars in private financial markets. The principle of covered interest parity suggests that the total cost of this route to acquiring dollars should be approximately the same as the cost of direct borrowing. The spread between the cost of indirect borrowing in dollars using euro/U.S. dollar FX swaps and the cost of direct borrowing in dollars, or the dollar basis, provides a measure of the stress in private dollar markets. Evidence on the movements of the dollar basis when swap lines are in place support the view that the swap line operations helped ease dollar funding strains on foreign banks (Fleming and Klagge 2010; Bahaj and Reis 2018). ${ }^{30}$

Third, while liquidity in currencies other than the dollar was available to the Fed as part of these reciprocal arrangements, these were hardly used, unlike in the 1970s when swaps were used by the Fed to stabilize the dollar. As of April 2009, the Federal Reserve put in place foreign-currency liquidity swap lines with the Bank of Canada, Bank of England, the European Central Bank, the Bank of Japan, and the Swiss National Bank, to support any operations it had to undertake to address financial strains in US markets, which required providing foreign currency liquidity to U.S. institutions. The lines involved provided access to $£ 30$ billion, euro 80 billion, up to $¥ 10$ trillion, and CHF 40 billion. These facilities were part of a network of bilateral swap lines among the six central banks. In October 2013, these swap lines were converted into standing arrangements. Interestingly, since 2009, barring small-value test operations, the Federal Reserve has not drawn on any of the foreign-currency liquidity swap lines. The Fed provided foreign exchange liquidity through swap lines but does not seem to have used such facilities to access non-dollar liquidity, even when available. ${ }^{31}$

Moreover, though the swap lines between these six developed country central banks formed a network within which any country could access the currency of any other, there were almost no instances of use of the swap facilities offered by central banks other than the Fed, by any of the members of this network. One reported exception is the Bank of England's use of its swap arrangement with the ECB in March 2019, which resulted from the financial stress resulting from the uncertainty associated with Brexit (Gros and Capolongo 2020). Once swaps began to be used primarily to alleviate foreign exchange shortages, it was shortage of dollar liquidity that really mattered, and the Fed was the main provider.

Finally, not all countries benefited directly from the Fed's offer of liquidity. In the early years the choice of swap partners clearly reflected the importance of a country in the pecking order of market economies, perceptions of risk from exposure to the country, and its role as a source of or as an intermediary in the flow of global wealth. To the extent that institutions from these largely developed countries are exposed in crisis-affected third countries not afforded access to Fed swaps, they can be protected by their central banks when financial turmoil affects the

\footnotetext{
${ }^{30}$ Bahaj and Reis (2018: 2) demonstrates that "the sum of the gap between the swap rate and the interbank rate in the source country, and the gap between policy and deposit central bank rates in the recipient country, provides a hard ceiling on the deviations of covered interest parity (CIP) between the two currencies", as if that ceiling is crossed an arbitrage opportunity arises.

${ }^{31} \mathrm{https}: / / \mathrm{www}$. federalreserve.gov/monetarypolicy/bst liquidityswaps.htm
} 
latter. But that does not protect national entities located in countries not supported by the Fed with swap facilities.

The Fed's engagement with developing countries, including those in Asia, was near absent till recently. Initially, the sole example of a swap arrangement with a developing country was a line for Mexico established in 1967, influenced by the special relationship the US had with that country. Starting at $\$ 130$ million that line grew to touch $\$ 700$ million in 1979 and was essentially meant to be used by Mexico to augment its reserves and deploy them for intervention in currency markets. In the 1980s, with the Mexican debt crisis breaking in 1982, the Fed provided Mexico special facilities of \$325 million in August 1982 and \$125 million in September 1989. These special lines were settled by 1991. However, in 1994, in a context of political uncertainty, the Fed and the Treasury joined hands to increase Mexico's swap line to $\$ 6$ billion. Later that year, with a peso devaluation and turmoil in Mexico's financial markets, the facility was enhanced to $\$ 9$ billion. However, during this time, Mexico too seems to have used the swap facility more as a backstop and relied largely on its own reserves to manage its currency, drawing only $\$ 1.5$ billion from the Fed's swap line, and clearing its swap obligations by January 1996. This preference for building and using reserves rather than piling up large forward dollar commitments through swaps is understandable, in as much as the latter strategy makes countries vulnerable to future dollar shortages.

But matters changed with the 2008 financial crisis and when the Covid-induced global crisis wrecked financial markets. In the latter case, the Fed, initially, only modified its thenprevailing standing swap arrangements with five foreign central banks by reducing the interest rate on use of the swap lines to near-zero and making funds available for longer periods of up to 84 days. However, a fortnight later, to widen the set of countries that can access dollar liquidity, it allowed countries to exchange their holdings of US Treasuries, which are leading instruments to park foreign reserves, for dollars, enhancing quick access to dollar liquidity. It then widened the set of countries for which it had swap arrangements with central banks, bringing in some emerging markets as well. On March 19, 2020, the Fed entered into temporary, six-month duration, U.S. dollar liquidity arrangements (swap lines) with a host of other countries. According to the Fed, these new facilities were created to support the provision of U.S. dollar liquidity in amounts of up to $\$ 60$ billion each for the Reserve Bank of Australia, the Banco Central do Brasil, the Bank of Korea, the Banco de Mexico, the Monetary Authority of Singapore, and Sweden's Sveriges Riksbank and \$30 billion each for the central banks of Denmark, Norway and New Zealand. This brought in emerging markets like Brazil, Korea and Mexico, and less important global financial centers like Singapore into the Fed's swap network. However, many countries that needed them were kept out. Bahaj and Reis (2018: 1) quote a Wall Street report of 2017 which said: "The governor of the Reserve Bank of India ... called on major central banks to extend their network of currency swap lines deep into emerging markets, saying a type of "virtual apartheid" in the provision of foreign currencies hampers efforts to fight financial instability."

Yet, this was a change from the situation in the past where foreign exchange stringency or scarcity forced most countries to turn to the IMF. With an increase in the number of central bank swap arrangements, they could turn to the Fed instead, though that option is even now open only to chosen emerging markets, besides some developed market economies. However, for all countries the Fed offered the option of providing financing against their holding of US Treasury securities.

This dominant role of the Fed has created a paradoxical situation. Both at the time of the 200708 crisis and in the 2020 Covid-induced economic crisis, the United States was one of the epicenters of the crises. Yet, that country and its central bank became crucial when mitigating 
the effects of the crises on financial markets. This is because, by virtue of being home to the world's reserve currency, and because the dollar still reigns supreme and is the favored safe haven for financial investors, the Fed is central to management of financial markets worldwide. Crises notwithstanding, the dollar dominates, and so does the Fed as the institution that manages the dollar.

Though dollar liquidity is the principal requirement in times of crisis, economic relations involving countries other than the US has encouraged swap lines in other currencies. Having allowed banks to issue mortgages in Swiss francs, central banks in Poland and Hungary were provided access to swap facilities by the Swiss National Bank. Given its dominance in the region, Japan has been a major source country for swap lines in Asia. Besides developed country central banks, the People's Bank of China had by 2018 established around a 100 swap lines involving a limit in excess of $\$ 1$ trillion with more than 40 countries (Reis and Bahaj 2018). Di Mauro and Zettlemeyer (2017) report an estimated 160 swap lines between different central banks across the world. The important difference here, however, is that given the preponderance of dollar-denominated real and financial transactions, the effectiveness of intervention by central banks other than the Federal Reserve depends on their willingness to swap any excess dollar reserves they hold. That is in the final analysis limited, since unlike the Fed they don't have the privilege of being able to issue dollars on an unlimited scale.

\section{Balance of payments vulnerability}

East Asian experiments at finding a safety net that can serve as an alternative to the failed AMF proposal have centered around such central bank swaps. Those experiments that began after the 1997 crisis continue to this day, having been through multiple modifications. This is because, the need for a crisis prevention and resolution framework in the East Asian region, revealed at the time of the 1997 crisis, has only increased over the last decade and a half, because of an increase in balance of payments and financial vulnerability. Enhanced vulnerability was the result of a substantial increase in cross-border capital flows, especially after 2004 when there occurred a surge in financial capital movements from metropolitan centers to emerging markets, fueled by the accommodative monetary stance and low interest rate policy adopted by developed country central banks, especially the US Fed.

Given this surge, the inability to build an effective "resolution mechanism" to address the vulnerabilities that the 1997 crisis revealed has had two implications. The first is the persistence of external fragility that could precipitate crises of much severity especially when countries are subject to shocks. The second is the consequent resort to foreign exchange reserve accumulation as a means of self-insurance against crises that has adverse implications from a long-term development point of view.

Balance of payments vulnerability can be reflected in persistent current account deficits and/or sudden spikes in the current account deficit (because of the 1970s oil shocks, for example). It could also be reflected in developments that increase the volume and likelihood of capital flight, either led by residents or by foreign investors who have accumulated assets in forms that allow for short run redemption and repatriation.

After 1997, vulnerability due to current account imbalances appear to have reduced in the main ASEAN member countries (Indonesia, Malaysia, Philippines and Thailand) and South Korea (which along with them was adversely hit by the Southeast Asian financial crisis). The intertemporal evolution of current account balances in these countries provide evidence of a structural shift in the aggregate current account balance they record starting with the financial crisis year 1997 (Chart 6). As opposed to consistent deficits between 1980 and 1997, varying 
between half a percentage point and close to 7 percentage points of GDP, the group records current account surpluses of 2-7 per cent of GDP between 1998 and 2007.

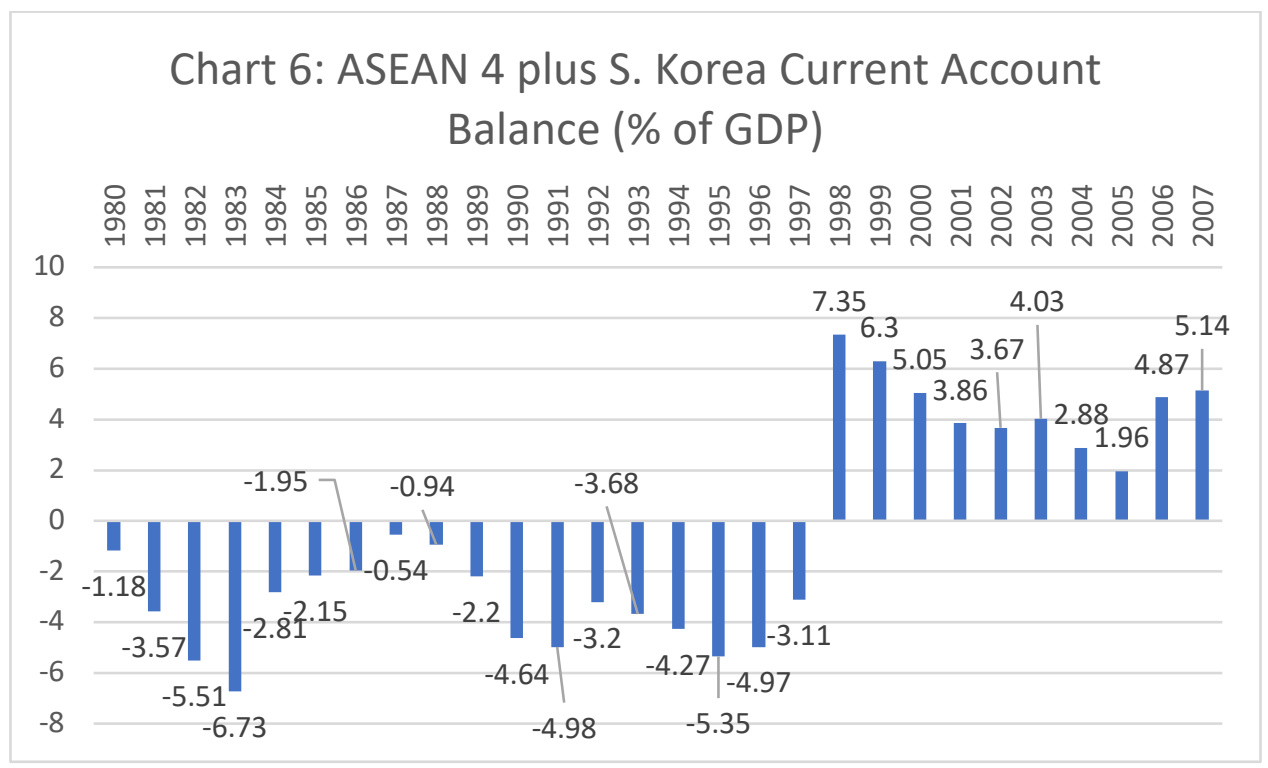

Source: CEIC at www.ceicdata.com

In the years preceding the 1997 crisis all of these countries recorded deficits on the current account of their balance of payments (Chart 7). After a sharp correction in crisis year 1998, when GDP in these countries shrank and compressed imports, they moved on to a trajectory in which they recorded current account surpluses in all years till 2011. The one exception was Thailand in 2005, when as a consequence of the tsunami in the region that country's exports were adversely impacted. Even after that, and through the global financial crisis year 2008, these countries did not record deficits. In the case of Korea, Malaysia, Philippines and Thailand, surpluses persisted even after that crisis with a couple of exceptional years in the case of Thailand. It was only Indonesia, affected by the end of the commodity price boom, and the Philippines, that recorded deficits after 2013.

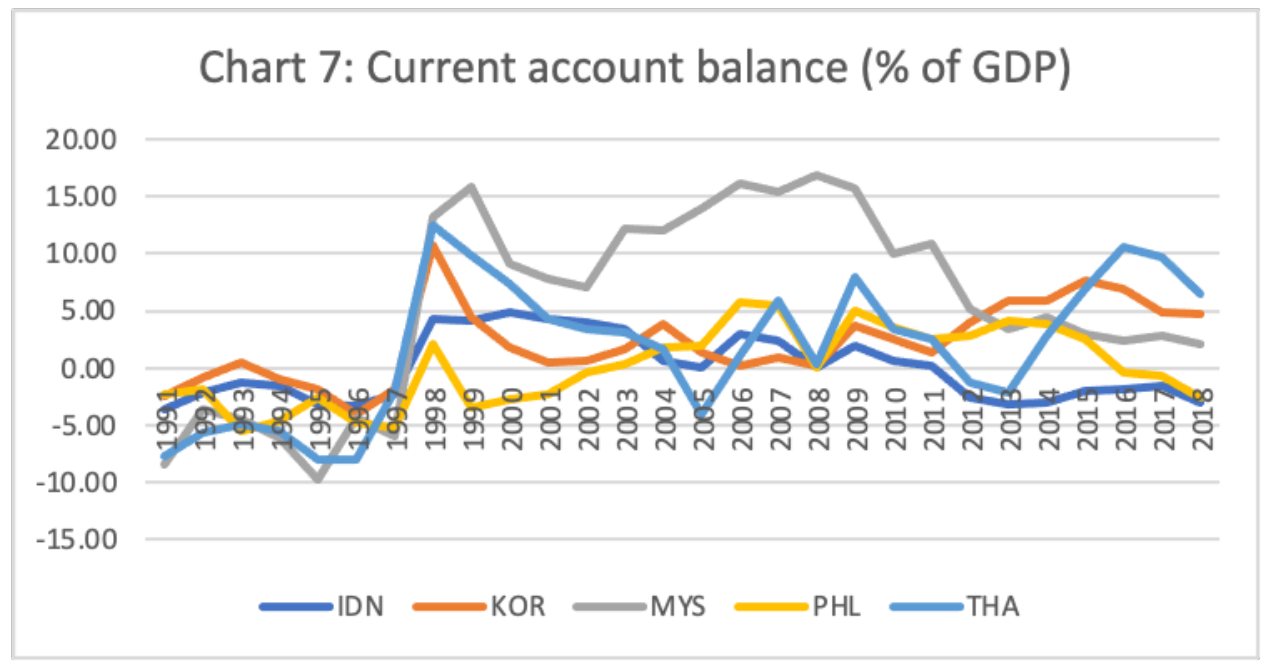

Source: World Bank, World Development Indicators database.

This rather definitive pattern of a shift from deficits to surpluses is missing in the case of the smaller ASEAN economies - Lao PDR, Myanmar and Vietnam - where the balances are much more volatile (Chart 8), pointing to their greater vulnerability, though that vulnerability comes 
from the import dependence of their economies in the case of Lao and Myanmar and from dependence on volatile commodity export revenues in the case of a country like Vietnam.

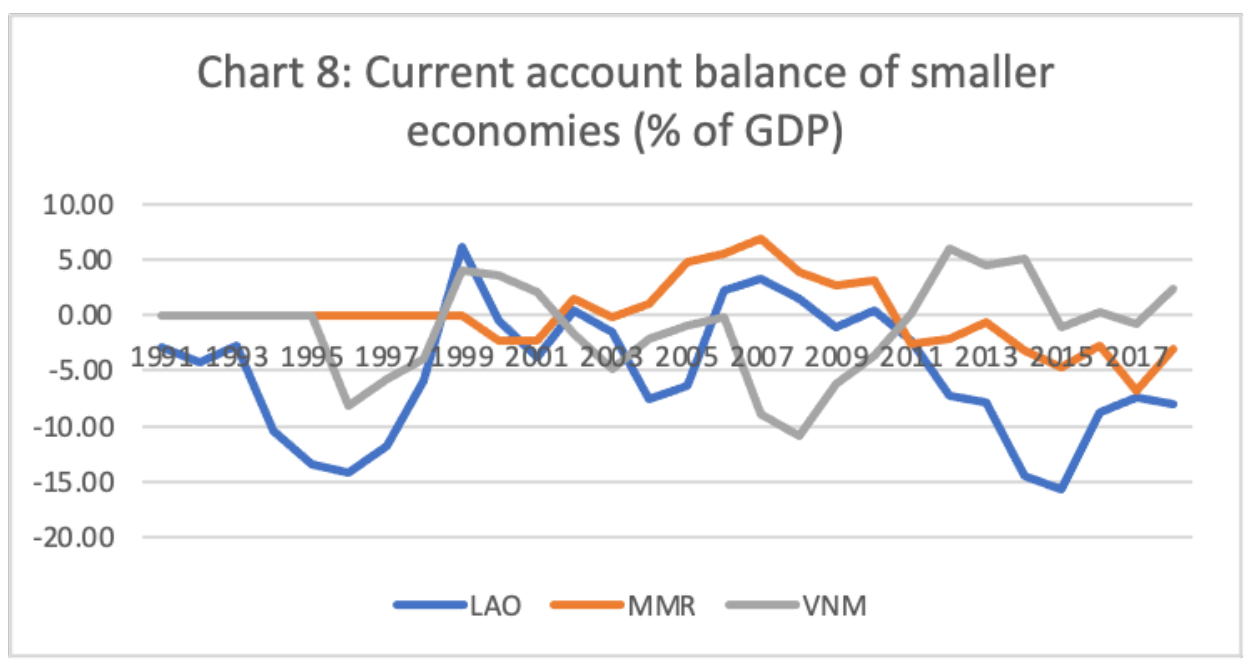

Source: World Bank, World Development Indicators database.

\section{The record on capital flows}

The vulnerability revealed by the 1997 crisis, though influenced by current account deficits, was also the result of enhanced flows of footloose capital to the larger ASEAN economies, especially short-term debt, in the years preceding the crisis. As reported at the start of this paper, gross capital flows to the region which had spiked before the 1997 crisis collapsed and remained low till 2004, when there was another period of buoyancy cut short by the 2008 global financial crisis. After that crisis, flows revived again in 2012 and were restored to high levels. This volatility points to the fact that a combination of the herd instinct characteristic of financial markets, the competitive thrust for speculative gains on funds garnered from profit-hungry investors, and the moral hazard generated by an implicit guarantee from the State that the financial system would be bailed-out in periods of crisis, all resulted in a situation where lending to and financial investments in particular countries tended to continue well after there was evidence that exposure had exceeded warranted limits. The corollary of this was that supply-side factors were likely to result in heightened volatility in financial flows to developing countries, with a surge in such flows followed in all likelihood by a sudden collapse of such flows. Moreover, when one or more countries become victim of such volatility and are faced with balance of payments difficulties and currency depreciations, contagion effects generated by expectations that other countries too would be similarly hit ensure that the latter too experience destabilizing capital movements. Thus, what started as a crisis in Thailand in 1997, soon engulfed Malaysia, Indonesia, and South Korea, besides some smaller economies in the region.

This raises the question as to whether such vulnerability reappeared once the capital flows that contributed to the crisis were reversed. Supply side factors that encouraged flows from the metropolitan financial centers to the so-called emerging markets were operative since the early 2000s, when liquidity in international financial markets registered huge increases, facilitated by a shift to easy and cheap money policies adopted by developed country central banks - a shift that persisted with a break, after the 2008 crisis. An indicator of the supply side push of capital this resulted in is the expansion of operations of international banks in less developed countries, especially the so-called "emerging markets". 
At the time of the East Asian crisis (end of June 1997), the international asset position of banks resident in 23 countries reporting to the Bank of International Settlements, stood at $\$ 9.95$ trillion, involving \$8.6 trillion in external assets after adjusting for local assets in international currencies (Bank of International Settlements, Monetary and Economic Department, 1997). ${ }^{32}$ By June 2007, when 40 countries were reporting, this had risen to $\$ 33.71$ trillion, with external assets totaling \$29.98 trillion (Bank of International Settlements, 2007). ${ }^{33}$ This expansion in international asset positions was not only the result of the increase in the number of reporting countries. ${ }^{34}$ The trend was visible in countries that reported on both dates as well. Thus, the international assets of UK-based banks had increased from $\$ 1.5$ trillion to $\$ 6.1$ trillion, and that of US banks from $\$ 0.74$ trillion to $\$ 2.8$ trillion.

Two consequences of this global surge in cross-border capital flow were increased inflows of financial capital into developing countries as well and an increase in the volatility of those flows. The IMF's estimates of net private financial flows to emerging and developing economies (Chart 9) point to a significant step up in annual flows between 1991 and 1996, with that trend moderating with the onset of the Southeast Asian financial crisis in 1997. Interestingly, the standard deviation of the values of net inflows rose from 19.1 for the period 1980 to 1989 , to 45.8 during 1990-98, suggesting that volatility increased as the volume of capital inflows went up.

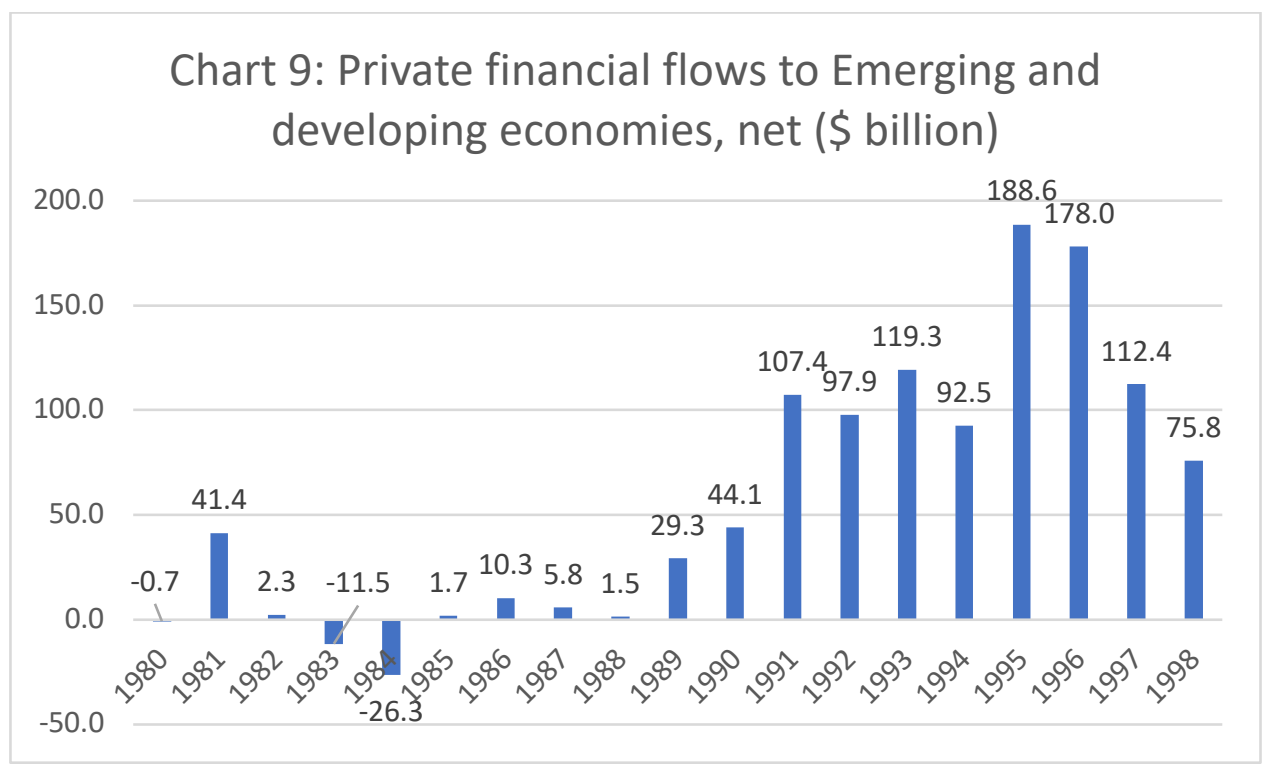

Source: IMF, World Economic Outlook, various issues.

Following the 1997 crisis, capital flows to the IMF's emerging and developing countries grouping remained subdued till 2003, from which year this group of countries experienced another surge in capital follows (Chart 10), which came to an end with the 2007-08 global financial crisis. During this surge, volatility increased even further with the standard deviation rising to 168.7 .

\footnotetext{
${ }^{32}$ Bank of International Settlements, Monetary and Economic Department. (1997, November). BIS Reporting Banks: Summary of International Positions. BIS Quarterly Review: International Banking and Financial Market Developments, pp. A-1-A2.

${ }^{33}$ Bank of International Settlements. (2007, December). BIS Reporting Banks: Summary of International Positions. BIS Quarterly Review: International Banking and Financial Market Developments , pp. A7-A8. ${ }^{34}$ Very often, countries that were not reporting have been characterized by small or negligible international exposure of banks operating from within their borders. There have been exceptions, such as the Republic of Korea that joined the countries reporting to the BIS only in 2005.
} 


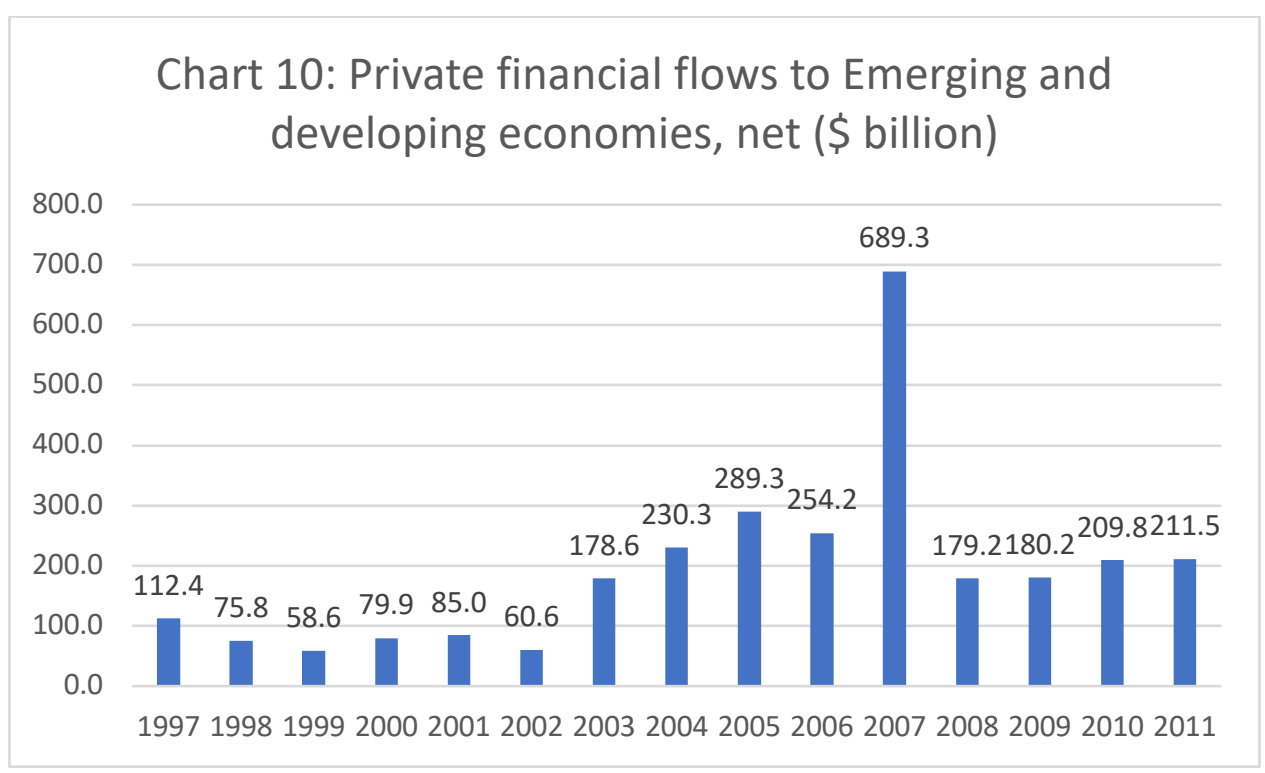

Source: IMF, World Economic Outlook, various issues.

Thus, trends in the ASEAN region as reflected by the experience of eight of ten ASEAN countries (excluding Brunei Darussalam and Singapore) are amplified versions of the trends in developing countries as a whole.

The aggregate trends, however, conceal sharp differences in experience across even this relatively small group of countries in one region. As Chart 11 shows, three countries accounted for the net outflows in the post-1997 period, viz., Malaysia, Singapore and Thailand. Indonesia proved to be dependent on significant inflows after the Global Financial Crisis (GFC) of 2008, and FDI destinations, such as the Philippines and Vietnam, showed no outflows or some inflow of capital. Smaller economies like Lao PDR and Myanmar were recipients of capital inflows, even if in relatively small volumes.

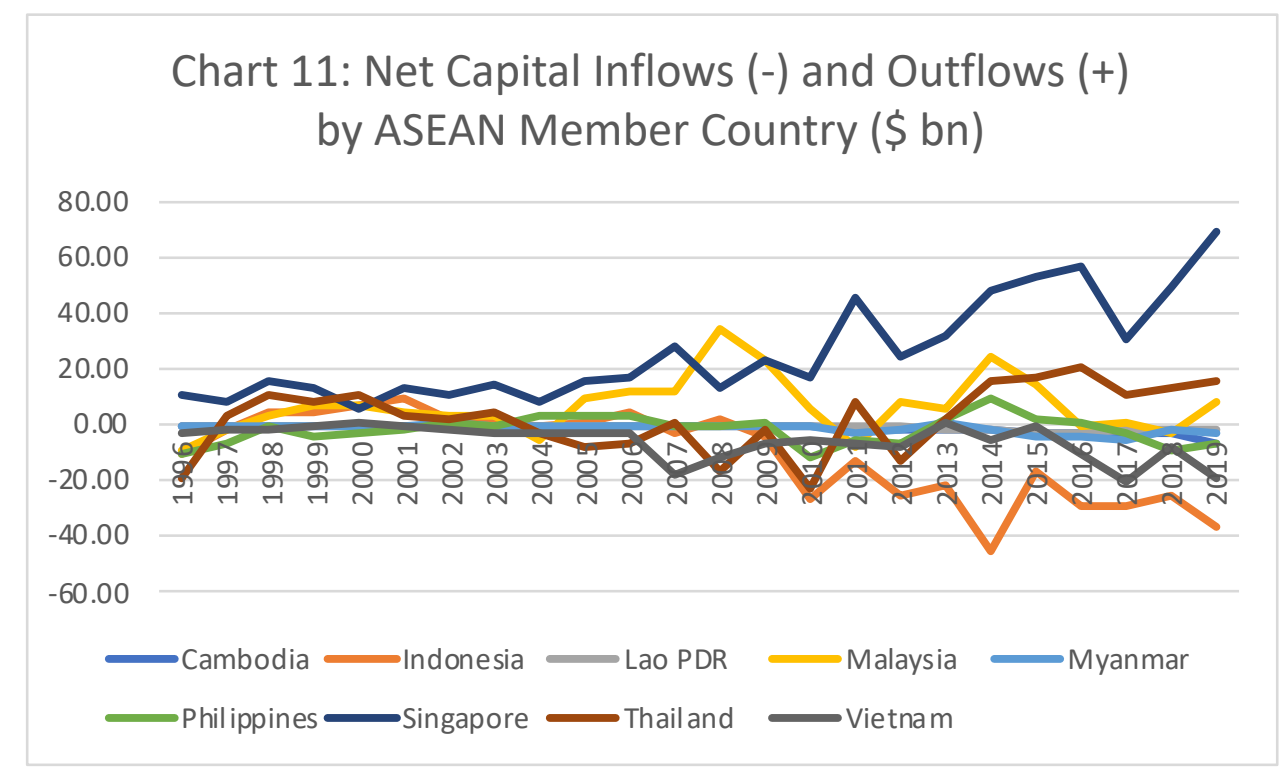

Source: IMF, Balance of Payments Statistics Database.

As compared to the experience of Malaysia and Thailand, which were severely hit by the crisis, another (non-ASEAN member) country from the region, South Korea, recorded a slightly different trajectory (Chart 12). In the years after the 1997 crisis, till the GFC, South Korea 
continued to receive net capital inflows, influenced perhaps by the drive on the part of foreign investors to acquire South Korean financial and non-financial firms at bargain prices, because of the asset deflation that followed the crisis. But after the GFC, South Korea's trajectory was also one characterized by significant net outflows of capital.

Besides South Korea, the other two of the plus-three in the ASEAN+3 grouping, China and Japan, also had very different trajectories with respect to net capital flows. As Chart 13 shows, net flows to these two countries were near mirror images of each other, with China almost consistently recording net inflows, except for 2014-16, and Japan net outflows. China's inflows are understandable given the role of the country as the global manufacturing hub, attracting foreign direct investment flows, with a significant share of manufactured exports accounted for by foreign invested firms. Japan, on the other hand, has been a major investor abroad, as an appreciating yen and rising domestic costs reduced its competitiveness as a location for world market production, forcing the relocation of manufacturing capacities.

Thus, the aggregate trends in capital flows are the result of particular developments that were the dominating influences in individual countries in different periods. In the ASEAN group, between 1998 and 2009, some countries experienced the aftermath of the Southeast Asian financial crisis, with international investors who had burned their fingers during that crisis choosing to stay away or withdraw, leading to aggregate net outflows, even if small. Subsequently, the effect of this factor, while persisting in some countries, was for the region as a whole neutralized by the global surge in capital flows.

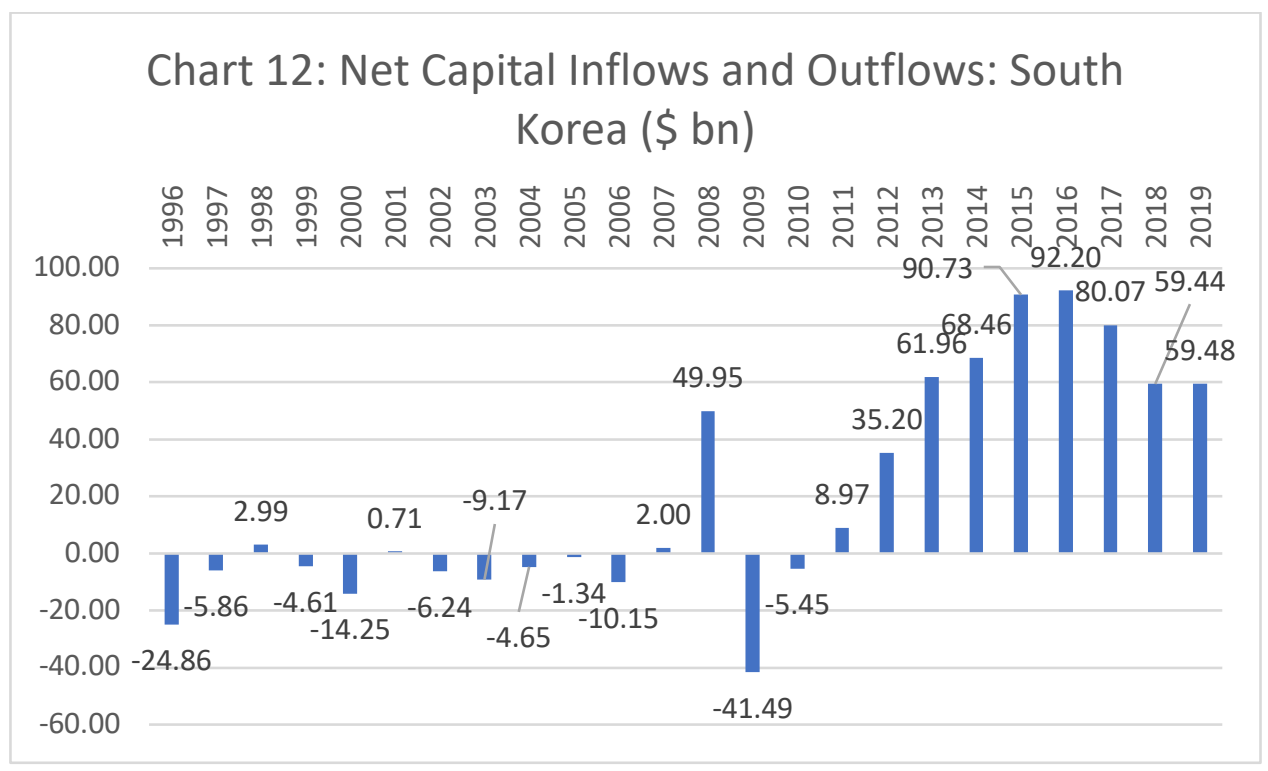

Source: IMF, Balance of Payments Statistics Database. 


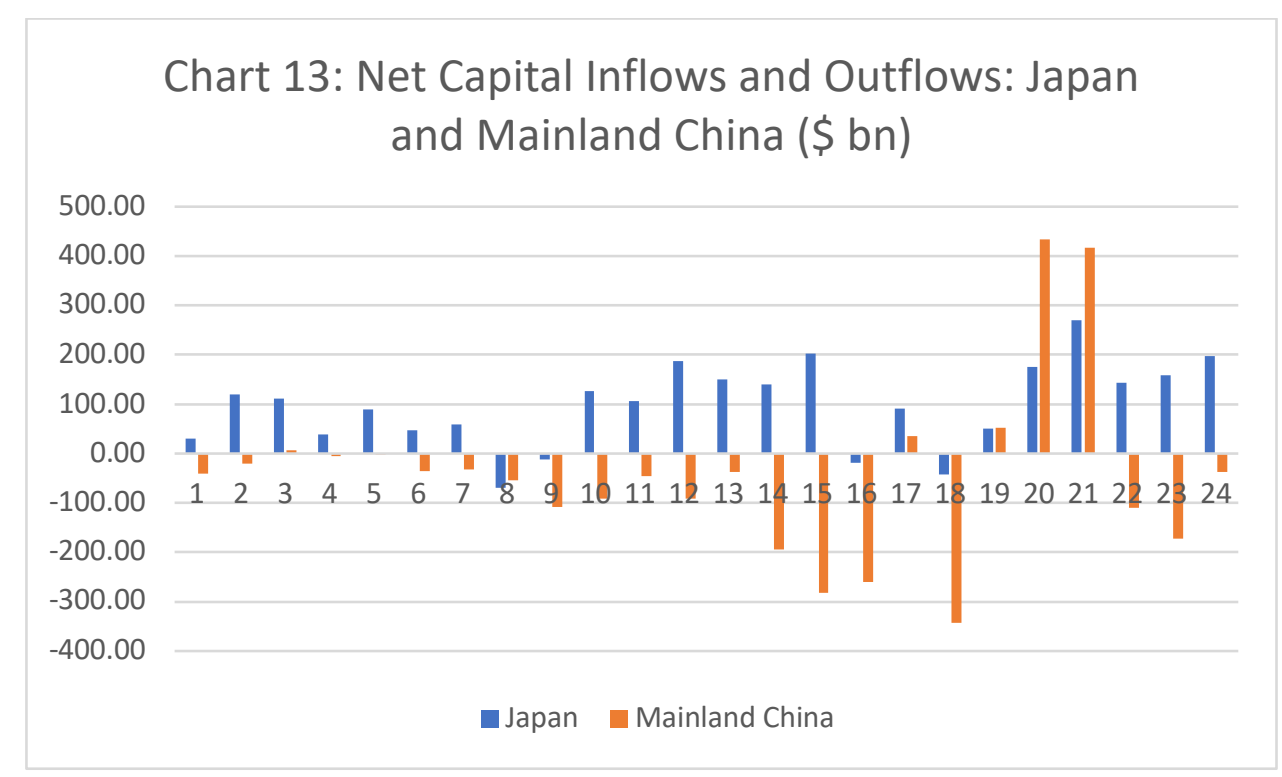

Source: IMF, Balance of Payments Statistics Database.

The GFC saw foreign investors booking profits to cover commitments at home or choosing to cut losses in destination countries, resulting in a short-lived but significant outflow in 2008 . But that was quickly reversed during 2009 to 2013, since the period after 2008 saw the global financial system riding on the massive liquidity injected into the system by the central banks in the developed countries, as they adopted "unconventional monetary policies" (quantitative easing and low interest rates) in response to the financial crisis and the Great Recession. Among the consequences of such monetary policies was a sharp spike in capital flows to some emerging markets, resulting in a huge increase in flows to India, Indonesia, and the Philippines.

The resulting supply-side driven push of foreign capital to emerging markets showed up as significant net inflows of financial capital till 2013 into some of the countries under examination. Around that time, recognition that monetary easing had gone too far and was fueling speculative investments in asset markets, led to fears that the policy of quantitative easing would be tapered out and interest rates would be raised. This triggered the "taper tantrum", with outflows of financial capital from many emerging markets, which were capped and even reduced by central bank assurances that there would be no significant policy reversals in the US, UK, Europe and elsewhere, on the grounds that the adverse effects of ending quantitative easing were holding back the recovery from the long Great Recession. 


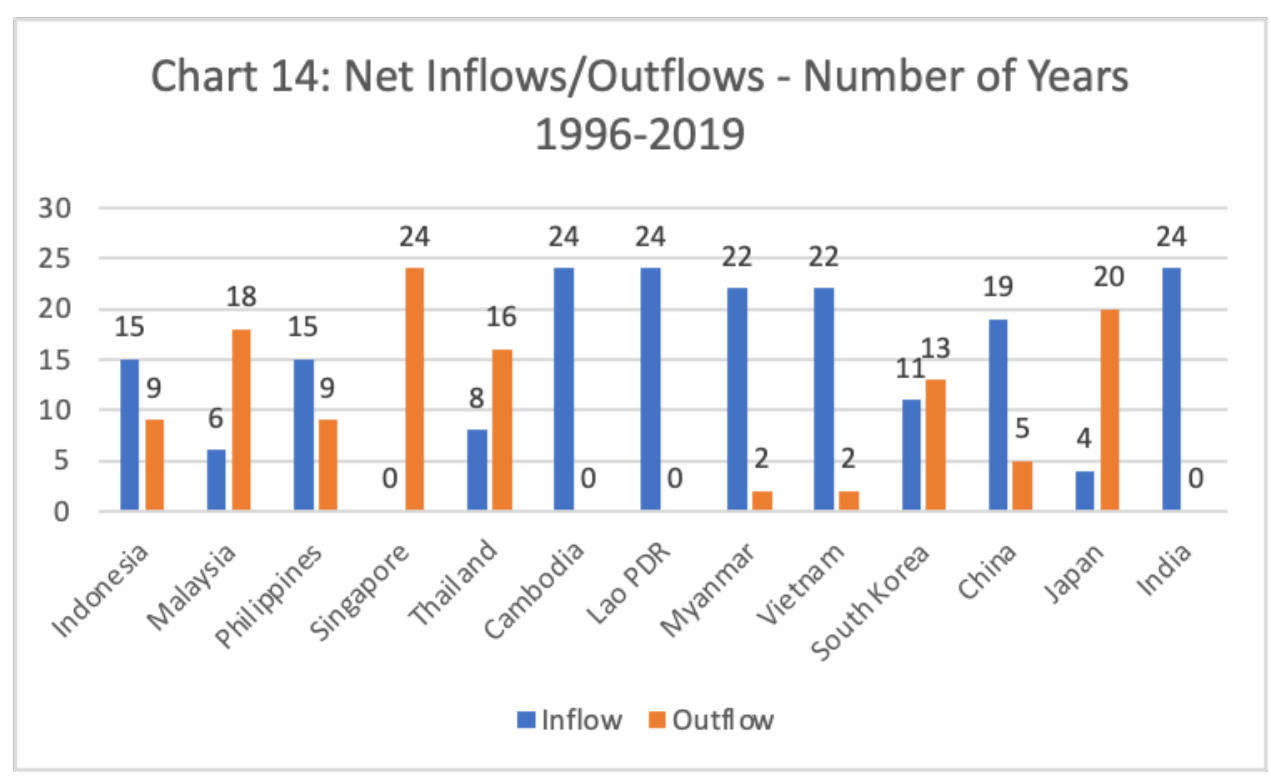

Source: Based on information from IMF, Balance of Payments Statistics Database.

Overall, the role of the countries being studied as sources or destinations of cross-border flows of capital varies across nations and time (Table 1). Chart 14 shows the number of years of net inflows and outflows for each country over the period 1996-2018. Over that 23-year period, the one country that consistently recorded net outflows of capital was Singapore. Japan recorded outflows in all but four years (2003-04, 2011, 2013), making that country also predominantly a source country for capital flows. The few net inflow years were on account of specific circumstances. For example, starting 2003, when there was a global surge in crossborder flows of capital, non-residents began to invest heavily in Japanese equity, with monthly net inflows averaging around $\$ 8.5$ billion. By 2006, foreign participation in Japanese stock exchanges had risen sharply, with monthly average share purchases by foreigners rising from 3.4 billion in 2000 to 13.1 billion in 2006. According to the IMF, foreign participation in stock markets accounted for "almost half of the daily turnover". This forced the Bank of Japan to (unsuccessfully) intervene in foreign exchange markets to prevent appreciation of the yen. ${ }^{35}$ The inflow in 2013 may have been influenced by the collapse in emerging market stock exchanges following the taper tantrum, which would have encouraged Japanese investors abroad to book profits/cut losses and repatriate investment.

\footnotetext{
${ }^{35}$ International Monetary Fund, Japan: Selected Issues, Staff Country Reports, 6 August 2007, Washington DC: IMF, p. 12.
} 


\begin{tabular}{|l|l|r|}
\hline \multicolumn{1}{|c|}{ Table 1: Sources of Capital Flow in Asia 1996-2019 } & Ratio of outflow years in total \\
\hline \multicolumn{1}{|c|}{ Country } & 1.00 \\
\hline Singapore & $1996-2019$ & 0.83 \\
\hline Japan & $1996-2002,2005-2010,2012,2014-19$ & 0.75 \\
\hline Malaysia & $1998-2003,2005-2010,2012-2015,2017,2019$ & 0.67 \\
\hline Thailand & $1997-2003,2007,2011,2013-19$ & 0.54 \\
\hline Korea & $1998,2001,2007-08,2011-19$ & 0.39 \\
\hline Indonesia & $1998-2003,2005-06,2008$ & 0.38 \\
\hline Philippines & $2004-06,2009,2013-16$ & 0.21 \\
\hline China & $1998,2012,2014-16$ & 0.08 \\
\hline Vietnam & $2000 \& 2013$ & 0.08 \\
\hline Myanmar & $2002 \& 2013$ & 0.00 \\
\hline India &.. & 0.00 \\
\hline Lao PDR &.. & 0.00 \\
\hline Cambodia &.. & \\
\hline Source: Based on information from IMF, Balance of Payments Statistics Database. \\
\hline
\end{tabular}

The second category in the selected countries when grouped in terms of their relative roles as sources of or destinations for capital includes a set of first and second tier new industrialisers in Southeast Asia consisting of Malaysia, Thailand, South Korea, Indonesia and the Philippines, for which the respective proportion of outflow years in the total of 23 varied from a high of 75 per cent in the case of Malaysia to close to 40 per cent in the case of the Philippines. Thus, these were countries which had a combination of net inflow and outflow years in the period since the Southeast Asian financial crisis which affected these countries particularly severely. These are all countries that by 1997 had liberalized their capital accounts significantly, and despite some efforts at reversal in Malaysia after the 1997 crisis, went through further capital control relaxation in the years following the crisis, partly under IMF influence. What is noteworthy is the years in which the net outflows occurred from these countries followed the 1997 crisis, or were centered around the 2008 crisis, and in the case of Malaysia, Thailand, South Korea and the Philippines, around the taper tantrum of May 2013 and the devaluation of the Chinese yuan in July 2015.

China and India are countries that fall in categories of their own. In China's case, despite recording large current account surpluses and accumulating substantial reserves, there were only 4 of the 23 years in which there were net capital outflows, pointing to the attraction of that country as a destination for foreign investors, initially as a target for direct investment flows and subsequently, as capital controls were relaxed, for portfolio investment. Even during the early phases of the Covid-19 crisis, when over a 70-day period starting January 21, 2020, \$92.5 billion flowed out of emerging markets covered by the Institute for International Finance, China remained an attractive target because it had opened up its bond market (the world's second largest) to foreign investors (Curran and Jamrisko 2020).

India has been included here because it stands out. It has not merely recorded net inflows in all 23 years, but in most of those years inflows exceeded current account financing requirements, resulting in an increase in reserves, as the Reserve Bank of India intervened to buy up dollars and stabilize the rupee. It was a major recipient of portfolio flows during the surge in cross- 
border flows after 2003. And barring crisis years 2008-09, it remained a target for portfolio investors when liquidity infusion after the GFC of 2008 and the Covid-induced crisis of 2020 set off a search for yield among portfolio investors who could access cheap liquidity in developed country, especially dollar, markets.

Finally, there are the small economies like Vietnam, Myanmar and Lao PDR, which because of flows of foreign aid and/or foreign direct investment remained destinations for capital flow. These were small in the case of Myanmar and Lao PDR, and where it was not, as in the case of Vietnam, there were outflows, as in the taper tantrum year 2013.

The source and motivation for capital flows suggest that, post-liberalization, in many of the countries being studied, the volume and direction of net flows depended not on the financing needs of recipient developing countries, but on the perceived benefits of arbitrage trades exploiting differentials in rates and returns between capital source countries and the destinations for the flows. When this triggers a surge in capital flows, the reserves of some recipient countries accumulate, not because they are earned (through current account surpluses) but are "borrowed" 36 by increasing liabilities that cost more than the return on the safe investments in which reserves tend to be invested. Besides the implicit loss of foreign exchange at a national level, this has implications for vulnerability to financial crises. Vulnerability has increased even more since the early 2000s also because investors have relied on access to cheap (near zero-cost) liquidity to undertake carry-trades of various kinds, rendering these flows sensitive to small changes in relative rates and extremely volatile.

A comparative examination of quarterly capital flows (Chart 15) for five countries (India, Indonesia, Korea, Philippines and Thailand) is revealing. Irrespective of whether a country records net inflows or outflows, volatility that became visible in the aftermath of the 1997 Southeast Asian financial crisis, amplified significantly in the years immediately preceding and following the 2008 global financial crisis.

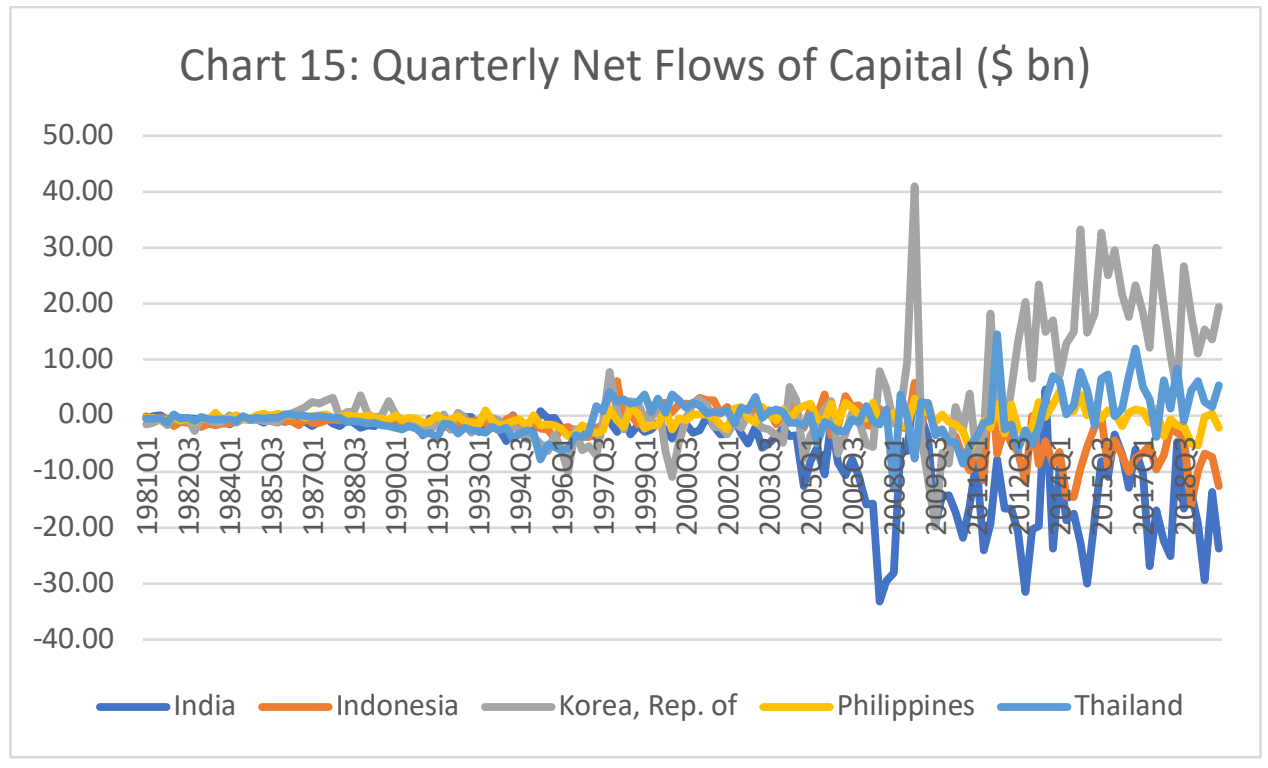

Source: IMF, Balance of Payments Statistics Database.

\footnotetext{
${ }^{36}$ To use the terminology adopted by Yilmaz Akyuz (2017).
} 
The strong evidence of increasing volatility combined with differential distribution of reserves strengthens the case for a regional arrangement to address financial and balance of payments volatility, supported by countries with more stable access to reserve holdings. In particular, the combination of reserve accumulation, current account surpluses in a context of growing regional trade, and capital inflows into leading Southeast Asian countries, suggested that the potential for use of swap arrangements permitting short-term flows of regional surplus reserves to countries in the region facing balance of payments difficulties to pre-empt regional crises did exist.

\section{The ASEAN Swap Arrangement}

Perhaps for this reason, when a regional effort was launched in East Asia to address the financial fragility revealed by the 1997 crisis, swaps of dollars for local currencies were the centerpiece. There was also a historical reason why, when the Asian Monetary Fund proposal failed to take off, countries turned to swaps as instruments for stabilizing the balance of payments and currencies of members. This was that countries in the region had accumulated knowledge of and experience with swaps. Well before the financial crisis of 1997 and before financial globalization had gathered momentum, ASEAN countries had experimented with regional swaps. An Appendix Table provides a summary of the changing nature of the swapsbased regional financial safety net in East Asia since then.

In August 1977, central banks and monetary authorities from the original ASEAN members (Indonesia, Malaysia, Philippines, Singapore and Thailand) came together to establish the (multilateral) ASEAN Swap Arrangement (ASA), with the express purpose of providing "immediate short-term swap facilities to participating ASEAN member countries with temporary international liquidity problems." 37 The Arrangement provided for the sale of US dollars against the domestic currency of the requesting participant, along with a forward purchase of the same amount of domestic currency by the requesting participant for US dollars. The transaction was to be for a period of one, two or three months, and could be renewed once for a maximum of another three months unless there were requests for use of the facility by other participants. The total available for swap transactions under the Arrangement was set at $\$ 100$ million, with the maximum total outstanding amount provided by each participant set at US\$ 20 million. The forward rate used was computed as follows:

Forward Rate $=$ Spot Rate $*(1+($ t.r $)) / 360$

where $t$ was the actual duration of the swap in days, and $r$ the interest rate for a Euro-dollar deposit for the relevant period as quoted by the Bank for International Settlements. It is noteworthy that the contribution to the arrangement of each of the five participants was equal and that, subsequently, it was made clear that any request for a swap from a participant central bank also had to be met with equal contributions from each of the other participants. Recognizing that some members may on occasion not have dollars to spare, it included a caveat that "if because of exceptional financial circumstances a participant is not in a position to provide its full share or has to refrain from swapping, the shortfall shall be met as far as possible by the other participants," subject to the $\$ 40$ million participation ceiling. Given the equal contributions and participation in swaps required as part of the agreement, the intention clearly was to prevent any member using the arrangement to increase economic influence.

The design and size of the arrangement partly reflected the balance of payments trends prevalent at the point of time it was put in place. To start with, the ambition in terms of dollar

37 "1977 Memorandum of Understanding on the ASEAN Swap Arrangements", Adopted in Kuala Lumpur, Malaysia on 5 August 1977, available at https://cil.nus.edu.sg/databasecil/1977-memorandum-of-understandingon-the-asean-swap-arrangements/. 
reserves committed was low, since the availability of "surplus dollar reserves" was limited for most of these countries. Secondly, the presumption was clearly that a country would need to access the swaps only because of temporary balance of payments difficulties of limited severity, which at that time would be substantially due to deficits in the trade and current account rather than capital movements. Thirdly, with membership restricted to the ASEAN nations, it must have been assumed that despite the geographically contiguous location of the membership and the economic links between them, it was unlikely that balance of payments difficulties would afflict the original members of the ASEAN simultaneously, and that the difficulty would spread because of contagion effects.

The original Arrangement remained effective for a period of one year from the date it came into force, but was extended by 6 supplementary agreements in 1978,1979, 1981, 1982, 1987, 1992 and 1997. The maximum total amount of dollars available for swap transactions under the 1978 supplementary agreement was raised to \$200 million, with the maximum total outstanding amount provided by each participant under the Arrangement set at $\$ 40$ million.

The process of renewal suggests that there were reasons why countries felt that keeping the arrangement in place was meaningful. The nature of the extensions indicate that the expectation was that the arrangement would be a permanent fixture. The duration of the second supplementary agreement was set at 3 years, with provision for modification by agreement and termination on any anniversary on request of any participant. The duration of the MoU was extended before expiry in 1981 by a further three years. A revised $1982 \mathrm{MoU}$ extended the duration for a further 5 years.

This was accompanied by a push to make this a complement of ASEAN membership. The Fourth Supplementary Agreement of $1987,{ }^{38}$ while extending the agreement for a further period of five years, reiterated that "participation in the Arrangement shall be confined to the central banks, monetary authorities or their equivalent bodies of ASEAN member countries." It provided for the entry into the arrangement of any "central bank, monetary authority or its equivalent body of an ASEAN member country who is not a signatory to this Fourth Supplementary Agreement," provided all existing signatories agree. It also, once again, reiterated that "the amount of swap requested by a participant shall be provided in equal shares by the other participants." Further, "the maximum outstanding amount of United States dollars received by any participant under the Arrangement" was not to exceed $\$ 80$ million at any point in time (decided on the basis of a gearing ratio of one-is-to-two). The agreement was extended again for five years with minor changes, and a Sixth Supplementary Agreement signed in crisis year 1997.

On March 1, 1997, the governments of Brunei Darussalam, the Republic of Indonesia, Malaysia, the Republic of the Philippines, the Republic of Singapore, the Kingdom of Thailand and the Socialist Republic of Vietnam, signed on to a Ministerial Understanding on ASEAN Cooperation in Finance as member states. This was a precursor to the Chiang Mai Initiative (CMI), which was launched in 2000. In July 1997, Lao People's Democratic Republic that had become an ASEAN member on 23 July, signed a protocol acceding to a host of ASEAN agreements, including the Memorandum of Understanding on the ASEAN Swap Arrangements. The Chiang Mai Initiative extended the ASA to cover all 10 ASEAN members, besides including China, Japan and South Korea from outside the ASEAN in the ASEAN+3.

\footnotetext{
${ }^{38} \mathrm{https} / /$ www.asean.org/storage/images/2012/Economic/AFMM/Agreement_on_Finance/Fourth\%20Supplemen tary $\% 20$ Agreement $\% 20$ to $\% 20$ the $\% 20$ Memorandum\%20of\%20Understanding\%20on $\% 20$ the $\% 20$ ASEAN\%20S wap\%20Arrangement\%20(1987).pdf
} 
Thus, well before the Chiang Mai Initiative, regional swap arrangements that could help ASEAN member countries tide over temporary balance of payments difficulties had become a central feature of regional cooperation in Southeast Asia. But the liquidity that could be accessed under the arrangement meant that it played a role only when balance of payments difficulties were of a minor nature. In 1981, when the total contribution of members to the arrangement was \$200 million, Indonesia's current account deficit stood at \$566 million, that of Singapore at \$1469 million, and that of Philippines, Malaysia and Thailand at \$2061 million, $\$ 2469$ million and \$2571 million respectively, making a total of \$9.1 billion. Not surprisingly, over the 20 years it was in existence till the 1997 Southeast Asian financial crisis, the ASA did not contribute much to resolving balance of payments difficulties of participant countries. It is reported that swaps under the ASEAN swap arrangement "were activated on five occasionsby Indonesia in 1979, Malaysia in 1980, Thailand in 1980, and the Philippines in 1981 and 1992 - in small amounts." Moreover, being "small relative to the trade and capital flows of the countries in the region ... these arrangements made only a minor contribution to the resolution of payments difficulties. During the crisis of 1997-98, the ASA was not activated." ${ }^{39}$

\section{The consequences of balancing power}

A noteworthy feature of the ASA was the implicit effort to prevent any imbalance in power among participants to the arrangement. The fall-out of that effort was three-fold. First, it allowed for equal contributions from each of the countries to the total fund available under the swap arrangement. This would imply that the 'capacity' to contribute of the smaller or economically weaker countries would set the ceiling on individual contributions and therefore the size of the fund. But this alone cannot explain the level at which the ASA was pitched. In 1977, the reserves of individual members of the initial agreement were as follows: Indonesia: $\$ 17.5$ billion; Malaysia: $\$ 21.5$ billion; Philippines: $\$ 8.7$ billion; Singapore: $\$ 71.4$ billion; and Thailand: $\$ 26.9$ billion. This amounted to a total of $\$ 146$ billion and meant that even Philippines with the lowest level of reserves contributed just 0.5 per cent of its reserves to the ASA. The reticence of countries to outlay significant sums may have been because of the difficulties of ensuring that repayment commitments were adhered too. Pressurizing a neighbor, which claims that it is unable to repay in time, could degenerate into a situation of political tension or conflict. The IMF, not being a 'nation' and constituted as a multilateral body with global membership does not face a similar problem when imposing its conditionality. Individual governments in a relatively small cooperation arrangement may not have the same flexibility.

Second, there was a contribution-linked ceiling set on how much could be borrowed by a single country in a swap, so that one or a couple of countries did not exhaust the available fund by virtue of having approached partners earlier and accessed much of the available resources. This may have made access to dollar liquidity through the ASA woefully inadequate in situations of substantial balance of payments difficulty. Third, the period for which a partner could exploit the arrangement was kept short, even allowing for extensions, so that others could obtain access in conditions where resources were stretched. The consequence of these rules was that the amount of support a country could access through the arrangement was limited in time as well.

These features suggest that a cooperative swap arrangement would require some features to work. First, the country which issues the principal reserve currency or a country (countries) that has substantial reserves of that currency has to be part of the arrangement. Failing that, the corpus will not be large enough to meaningfully resolve balance of payments difficulties of any individual member, even when cross-border financial flows are limited. Second, since

\footnotetext{
${ }^{39}$ See "The Chiang Mai Initiative", Chapter 3 of Henning (2002: 14).
} 
making equal contribution and participation a requirement militates against ensuring adequacy of resources, the differential influence stemming from differential contributions will need to be accepted. Third such differential influence and even emergence of a dominant player can help discipline those accessing the corpus, to ensure that they adopt measures that would enable them to return the dollars accessed and that they actually do so. This means that surveillance and enforcement would be required for countries to be willing to part with their dollar reserves to support the arrangement, even if temporarily.

These requirements became crucial as external financial liberalization and enhanced cross border financial flows substantially increased the volume of dollar liquidity that would be needed to address balance of payments difficulties or crises. If an institution like the Asian Monetary Fund had been created, it would have received support from countries with large reserves, could leverage that support to provide assistance of meaningful dimensions, and take on the responsibility of terms setting, surveillance and enforcement. But even in that case the power of the leading donors or donor to the initial corpus would be visible, though not direct. Acceptance of that leadership by other members of a multilateral institution would have been crucial. One reason the AMF failed was the absence of such a consensus.

\section{The CMI's swap arrangements}

By the time of the 1997 Southeast Asian financial crisis, balance of payments difficulties were not the result mainly of current account deficits, but of volatility in capital flows. A common feature of the external exposure of the countries experiencing crisis in 1997 was excessive exposure to footloose foreign capital, especially short-term debt. Such exposure was large in the case of Thailand, Philippines, Indonesia, Malaysia and South Korea, amounting to 399 per cent, 580 per cent, 810 per cent, 261 percent, and 441 per cent respectively of foreign reserves excluding gold (Table 6). ${ }^{40}$ When investors and creditors turned wary and chose to pull out or hold back on debt rollovers or provision of new credit, a crisis ensued.

The crisis made clear that any regional arrangement to address those difficulties without US or IMF involvement had to be far more ambitious than the ASA. That required countries in the region with large surpluses to step in and play a role. That was what Japan was seeking to do with its proposal of a regional alternative to the IMF. But with the failure of the Asian Monetary Fund proposal, countries in the East Asian region were forced to focus on revamping the ASA, to create a regional cooperation arrangement that could meaningfully address external vulnerability and instability.

An agreement on a special swap framework to address the vulnerabilities revealed by the 1997 financial crisis was arrived at in a meeting of Asian Finance Ministers and Central Bank officials in Manila, Philippines held 18-19 November 1997 and for that reason was labelled the "Manila Framework" ${ }^{41}$ Having been provoked by the Southeast Asian crisis the agreement was ASEAN-centered. Since it recognized the need to bring in participants with adequate dollar reserves, membership in the new arrangement was expanded to the ASEAN+3 (ASEAN plus Japan, the People's Republic of China (PRC) and South Korea). But in an almost self-defeating turn, the framework agreement gave a role for developed countries outside of the region, especially the US, and for the IMF. Having succumbed to pressure from the US and the IMF

\footnotetext{
${ }^{40}$ Figures are based on data available in the dataset underlying Philip R. Lane and Gian Maria Milesi-Ferretti (2017).

${ }^{41}$ According to Grimes (2009), the Manila Framework Group was the result of an effort by the US to counter the damaging effects of its successful blocking of the AMF, with an alternative regional arrangement to address financial fragility that did not undermine the then prevailing global order. The group itself was disbanded at the end of 2004.
} 
on the AMF, those involved in defining the framework agreed to accommodate US influence in any new arrangement.

The Manila Framework reflected the degree to which countries in the region, despite their recent experience with the damaging conditionalities imposed by the IMF, had agreed to accept the dictates of that organization and the US when formulating their own response. The agreement was described as "A New Framework for Enhanced Asian Regional Cooperation to Promote Financial Stability", and the Summary of the Discussions at the meeting explicitly noted that the "framework, which recognizes the central role of the IMF in the international monetary system, includes the following initiatives: (a) a mechanism for regional surveillance to complement global surveillance by the IMF; (b) enhanced economic and technical cooperation particularly in strengthening domestic financial systems and regulatory capacities; (c) measures to strengthen the IMF's capacity to respond to financial crises; and (d) a cooperative financing arrangement that would supplement IMF resources." (Emphasis added. $)^{42}$ The summary was clear that whatever arrangements for surveillance and financing were designed would only "supplement" the IMF's efforts, with subjection to an IMF program required for funding in excess (initially) of 10 per cent of the swap-mediated borrowing quota of a country. ${ }^{43}$ This clause was reportedly included at the insistence of Japan, which wanted to appease the US. ${ }^{44}$ China and South Korea accepted the clause, perhaps because they saw it as a means of limiting Japanese influence in the region. As before there was no country from Asia that was recognized and accepted as leader in the regional cooperation effort. But leadership to design terms, undertake surveillance and enforce conditionalities had been almost wholly handed over to the IMF, and implicitly through it to the US.

To signify that the Manila Framework went beyond a purely ASEAN agreement, the meeting that endorsed it, held in Kuala Lumpur, Malaysia, on 2 December 1997, included finance ministers from outside the ASEAN, from Australia; the People's Republic of China; Hong Kong, China; Japan; the Republic of Korea; and the United States. Included among the cooperating partners in the Manila Framework were the US, the IMF and the World Bank, with representatives of the Bretton Woods institutions present at the meeting. This was clearly no regional alternative to the IMF of the kind that the AMF was meant to be.

On the sidelines of that event, the first meeting of those who would implement the framework, in the form of the ASEAN+3 (ASEAN plus Japan, the PRC and Korea) was held, which led up to the Chiang Mai Initiative (CMI) of 2000, which was an agreement on regional financial and monetary cooperation based on central bank foreign exchange swaps. The initiative drew its name from the location of a meeting of the ASEAN+3 held in May 2000 at which it was launched. Among the principal areas for regional cooperation identified at that meeting were

\footnotetext{
${ }^{42}$ Quoted in Sussangkarn and Manupipatpong (2015: 108). Overall, the meeting identified ten areas for regional cooperation.

${ }^{43}$ Ten percent of the eligible swap sum was the "delinked portion". Even prequalification under the IMF's Contingent Credit Line (CCL) was seen as inadequate, with insistence on activation of IMF conditionality and surveillance a prerequisite for accessing a swap under the Chiang Mai Initiative.

${ }^{44}$ Narine (2003), p. 83. A January 2000 report from the Prime Minister's Commission on Japan's Goals in the $21^{\text {st }}$ Century argued as follows: "If the IMF can be likened to a major hospital caring for the world as a whole, then we should consider supplementing it with the establishment of an Asian Monetary Fund to serve as a 'family physician' to provide care at a more intimate level. We have reached the stage at which we should take a multilevel approach in the field of finance as well, responding both globally and locally." Prime Minister's Office, Government of Japan; Prime Minister's Commission on Japan's Goals in the 21st Century, The Frontier Within: Individual Empowerment and Better Governance in the New Millennium, 18 January 2000. URL: http://www.kantei.go.jp/jp/21 century/report/htmls/7chap6.html. According to Henning (2002) even the 10 per cent delinked portion, representing "short term liquidity support", was included only as a concession to Malaysian Prime Minister Mahathir Mohamad, who had objected to the IMF-link.
} 
the monitoring of capital flows, creation of a swap network, and the setting up of a regional surveillance mechanism.

\section{The Chiang Mai Initiative}

The Chiang Mai Initiative launched in the aftermath of the 1997 crisis built on the foundation provided by the ASA. The Memorandum of Understanding on the ASEAN Swap Arrangement, provided for in the CMI of 2000, superseded, in effect, the 1977 ASA and its Supplementary Agreements and amendments. As noted earlier, in a major departure from ASA, influenced by the role of capital movements rather than just current account disorder in driving the 1997 crisis and determining its severity, the CMI recognized that without bringing in countries that held a large share of the regional surpluses, any regional cooperation framework based on swaps would not be adequate. This clearly explained the ASEAN+3 membership in the CMI.

The CMI declaration defined the objectives and nature of the swap network as follows:

"In order to strengthen our self-help and support mechanism in East Asia through the ASEAN+3 framework, we recognized a need to establish a regional financing arrangement to supplement the existing international facilities. As a start, we agreed to strengthen the existing cooperative frameworks among our monetary authorities through the "Chiang Mai Initiative". The Initiative involves an expanded ASEAN Swap Arrangement that would include ASEAN countries, and a network of bilateral swap and repurchase agreement facilities among ASEAN countries, China, Japan and the Republic of Korea." (Emphasis added)..$^{45}$

The addition of special bilateral arrangements, which was the major advance registered through the CMI, largely between the ASEAN countries on the one side, and China, Japan and the Republic of Korea on the other, reflected the recognition of the presence and asymmetric distribution of reserves among this group of countries.

In the immediate aftermath of the 1997 crisis, Japan's Finance Minister Kiichi Miyazawa, when arguing for an Asian Monetary Fund that never got established, had declared: "I am thinking of a plan where the countries of the region put up money to forestall speculative attacks. There are nations in this region, such as Japan, China and Hong Kong, which can put up sizeable amounts of money," he reportedly said (Tett 1999). In fact, CMI-style regional cooperation was encouraged in 1997 and thereafter because some countries in the region had accumulated significant volumes of foreign exchange reserves. While the total currency reserves of the ASEAN+3 stood at $\$ 719$ billion at the beginning of 2000, Japan and China held $\$ 294$ billion and $\$ 161$ billion respectively, or a total of $\$ 455$ billion. Besides reserves of these countries, the region also had substantial reserves with Hong Kong (\$96.3 billion) (Henning 2002: 13).

What was important was that, in the case of some of these countries, reserves had been accumulated by running up persistent current account surpluses. They were not borrowed reserves. In 1997, for example, three Asian countries - Japan, China and Singapore-were running current account surpluses. Their combined surpluses totaled $\$ 135$ billion. This singleyear surplus was substantially more than needed to cover single year deficits in the affected countries. The combined deficits of the ASEAN 5 (Thailand, Indonesia, Malaysia, Philippines and Singapore) stood at $\$ 3.3$ billion and the surpluses of the Plus 3 (Korea, China and Japan) at $\$ 125.5$ billion, after accounting for Korea's deficit of $\$ 8.3$ billion. There was a net surplus

45 "The Joint Ministerial Statement of the ASEAN+3 Finance Ministers Meeting," May 6, 2000, Chiang Mai, Thailand available at https://aseanplusthree.asean.org/wp-content/uploads/2020/01/The-Joint-MinisterialStatement-of-the-ASEAN.pdf. 
in the group of $\$ 122$ billion, giving it considerable leeway to address the problem of foreign exchange stringency, even if that resulted from capital outflows, in individual countries in the region. If a significant proportion of these regional reserves could be diverted to help countries faced with balance of payments difficulties, the sum involved would compare with what they could have then accessed from the IMF and developed countries outside the region.

The presence of these reserves and surpluses did offer an opportunity for greater regional cooperation. With the CMI, it appeared that countries other than Japan, who had the wherewithal, would take on part of the responsibility of addressing regional crises that the US was unwilling to shoulder, and Japan had taken up through the Miyazawa Initiative. But the IMF would play a role and serve as a proxy for US leadership.

\section{The threat of domination}

When designing the CMI, the question must have arisen how the more 'democratic' and equitable burden-cum-access sharing character of the ASA could make way for an environment in which the plus-3 (China, Japan and Korea) dominated. Given the economic weight of these countries and their large foreign reserves, there could be no pretense that they would be on the same footing as the ASEAN members in the arrangement, especially if the arrangement was backed by funding of a magnitude that was meaningful ${ }^{46}$ There was also the question of how the interests of these three countries, especially China and Japan, would be balanced, so that their agreement to an arrangement could be sealed.

In practice, this seems to have been achieved by providing two pillars to the arrangement. One was the enhanced ASEAN Swap Arrangement. However, the enhanced ASA that was the first pillar of the Chiang Mai Initiative did not significantly increase funding under the arrangement, raising it from $\$ 200$ million to just $\$ 1$ billion. The period of time for which an applicant can access these reserves was, however, increased, with members made eligible to borrow up to two times their contribution for a period of six months (extendable for another six). Members consisted of new ones from ASEAN and the prior members of the ASA. The prior members also designated as 'tier 1' members (Brunei, Indonesia, Malaysia, the Philippines, Singapore and Thailand) contributed $\$ 150$ million each under the revised arrangement, and the 'tier 2' members made the following contributions: Vietnam \$60 million; Myanmar \$20 million; Cambodia \$15 million; Lao PDR \$5 million. The liquidity accessible under this pillar was therefore enhanced by providing for differential contributions but was still limited.

The second pillar was the network of bilateral swap arrangements (BSAs) under which countries could opt for a swap of currencies up to an agreed amount. The CMI provided for negotiation of 33 bilateral currency swap arrangements of which 30 were between each of the Northeast Asian nations (China, Japan and South Korea) and each of the 10 ASEAN members and 3 were between the Northeast Asian nations themselves. The arrangements among the big3 were possibly symbolic and aimed at giving the scheme a regional cooperation flavor. The architecture of the second pillar was not clearly specified, perhaps to win agreement. The individual swap arrangements were bilateral, independent of each other, varied in size and did not require depositing the promised contribution in a common fund.$^{47}$ By 2007, the aggregate sum involved in all swap agreements under the CMI stood at $\$ 83$ billion (Figure 1). This was

\footnotetext{
${ }^{46}$ The dominant position of the 3 non-ASEAN countries in the arrangement comes through from the decision to have two rotating co-chairs, of which one is from the ASEAN and the other from the +3 , giving the latter a persistent leadership role (Grimes 2009).

${ }^{47}$ The interest rate on borrowing through the swap was, significantly, set at the IMF drawing rate, which is calculated taking account of the actual costs of funds plus an IMF overhead, making it relatively more expensive (Grimes 2009).
} 
considerable by the standards of the first pillar, and a major step forward, though in the event of a severe crisis involving multiple countries of the 1997 kind, the liquidity available under this pillar was likely to be inadequate. ${ }^{48}$ Further, geopolitics seems to have ensured that behind the façade of a regional cooperation framework, the firepower rested in bilateral agreements with no centralizing pool of resources or a central monitoring framework.

The issue of not handing over too much power to any one of the plus-3 countries still clearly mattered. The understanding was that when a country had access to multiple bilateral swaps, it must access resources proportionately from each of the arrangements rather than rely on one, till exhausted, and then turn to the others. This was what gave it a multilateral flavor. But, as under the ASA, when approached by an applicant, a country running a mutually agreed swap line could opt out, initially in "exceptional financial circumstances", but subsequently at will. In which case, it is left to other countries that had arrangements with the applicant to take up the slack. Thus, participation in any exercise providing liquidity through swaps to a member was automatic, and non-participation voluntary. Since more than one country can be involved in providing support to an applicant when needed, one of them was expected by agreement to take on a coordinating role, in the absence of a secretariat to which those powers were delegated. An informal framework of this kind was in effect papering over the conflicts and tensions that history and geopolitics had embedded in the region.

Besides pressures from the US and the Bretton Woods institutions of the kind experienced at the time of the debate over a potential AMF, these conflicts possibly also partly explained the decision to outsource the task of monitoring and surveillance of countries availing of the swaps under the arrangement to the IMF. The objectives of the bilateral swap arrangements were identified as provision of balance of payments support and short-term liquidity support. Though the rules governing individual swaps were bilaterally negotiated and not always disclosed, a broad framework of principles was agreed upon, which most importantly included a link with an IMF program with conditionality and monitoring, with no real regional monitoring. Beyond a specified borrowing limit, which possibly separated what was considered short-term liquidity support and balance of payments support, a borrower was required to have entered into an agreement with the IMF and be subject to the latter's conditionality and surveillance to be eligible. Initially any swap in excess of 10 per cent of a countries eligible support, which was the specified IMF-delinked portion, required IMF surveillance. That was raised to 20 per cent at the 8th ASEAN+3 Finance Ministers' Meeting held in May 2005 in Istanbul, Turkey, when the size of the ASEAN swap arrangement was also raised from $\$ 1$ billion to $\$ 2$ billion. ${ }^{49}$

One factor that possibly explained the support for IMF surveillance especially on the part of China and South Korea, was the fear that this role would by default be taken on by Japan, given its dominant position in the region at that point in time. William Grimes (2009 and 2011: 80), a long-term and keen observer of regional financial cooperation in Asia emphasizes that "the need for third-party enforcement through the IMF link arises from the politics of Sino-Japanese rivalry and therefore cannot be eliminated through institutional measures."

The resort to the IMF was also partly explained by fears that given conflict between major surplus holders, borrowing countries could play one lender against the other to avoid accepting

\footnotetext{
${ }^{48}$ Henning (2002) estimates that, together with facilities under the ASA, BSAs concluded by around 2001 provided access to funding that varied from 1.3 times its IMF quota in the case of Indonesia to 4.6 to 4.8 times for Thailand and the Philippines.

49 “The Joint Ministerial Statement of the 8th ASEAN+3 Finance Ministers' Meeting Istanbul, Turkey” accessed at https://asean.org/the-joint-ministerial-statement-of-the-8th-asean3-finance-ministers-meeting-istanbulturkey/.
} 
unpalatable conditions designed to strengthen the possibility of repayment. According to Amyx (2002), China and South Korea favored close linkage to IMF programs. This was explained as being a way of minimizing demands on their reserves and ensuring repayment. Amyx (2002: 15) reports that, "China, in particular, stood firm in its insistence that the arrangements be closely linked to IMF programs and argued for 100 per cent linkage. At the other end of the spectrum, Malaysia insisted that no linkage to the IMF was necessary. Malaysia already had in place a swap with Japan that was not linked to the IMF and had thus far been able to avoid IMF involvement in rebuilding after its crisis; therefore, Malaysian officials were particularly upset by the introduction of the IMF at this stage."

Figure 1 provides details of all swap arrangements that were in place under the CMI before the onset of the global financial crisis in 2007.

Figure 1

The Agreement on the Swap Arrangement under the Chiang Mai Initiative (as of July 10, 2007)

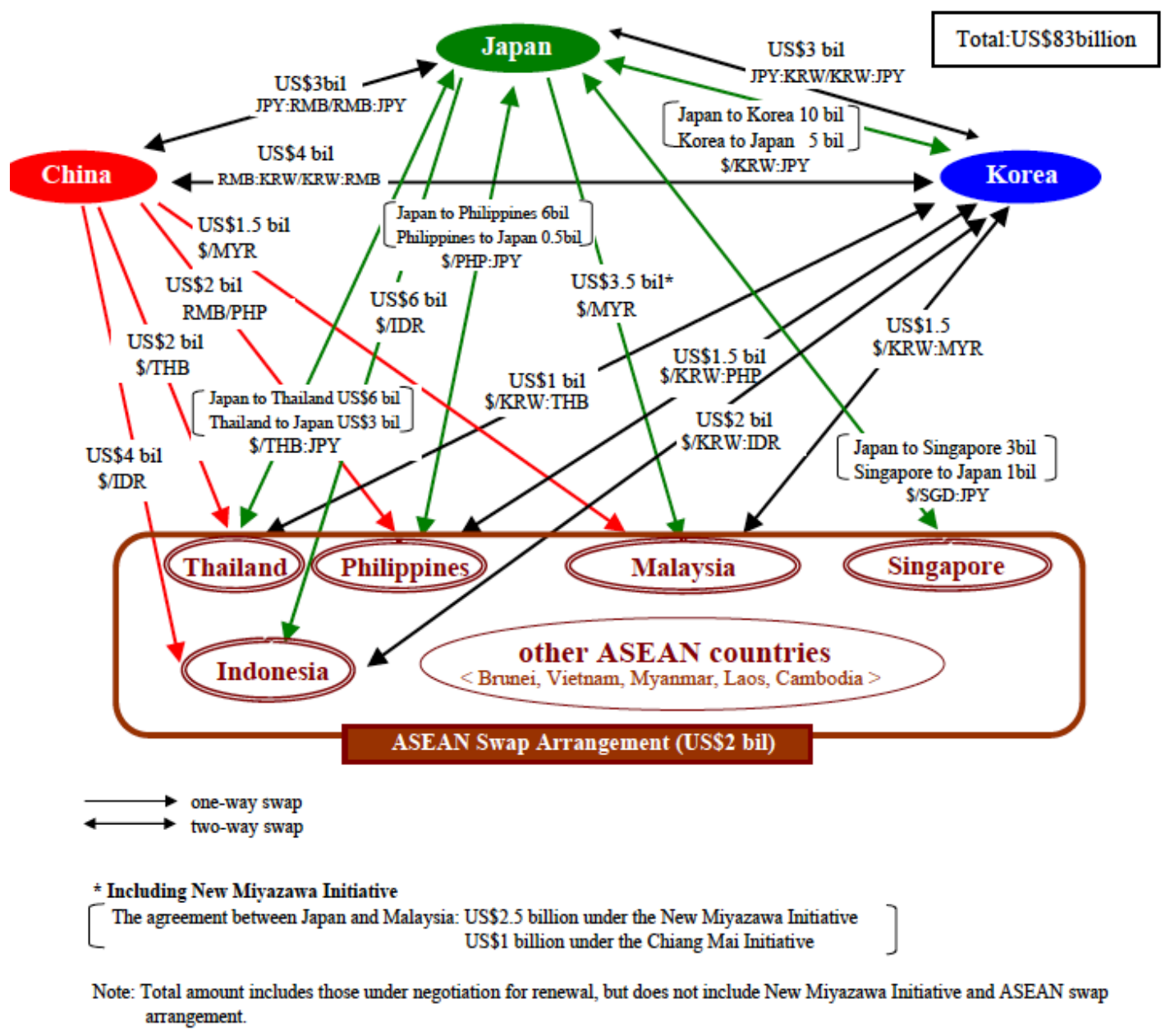

Source: Bank of Japan at

https://www.boj.or.jp/en/announcements/release_2007/data/un0707a.pdf. 


\section{Multilateralizing the CMI}

As capital flows to emerging markets surged, the ASEAN+3 countries did attempt to strengthen the regional safety net to address crises that could result from increased vulnerability. This was done by modifying the CMI to yield the Chiang Mai Initiative Multilateralization (CMIM) arrangement. As early as May 2007, ministers assembled at the 10th ASEAN+3 finance ministers' meeting in Kyoto, Japan decided to begin a process of 'multilateralizing' the CMI by merging and pooling the separate bilateral swap arrangements. The Joint Ministerial Statement said "...we unanimously agreed in principle that a self-managed reserve pooling arrangement governed by a single contractual agreement is an appropriate form of multilateralization." 50 When implemented, countries would have access to a much larger swap corpus from a single source, without being subject to the influence of individual countries with whom it would have to negotiate. This was one more effort at making the regional financial cooperation effort meaningful. The need for strengthening the regional arrangement through multilateralization was only underlined when at the time of the 2008 global financial crisis, countries in the region chose not to resort to funding from the CMI.

The decision to pool the swaps raised the issue of who would take over the regional monitoring role, which earlier was played by a coordinator chosen by a group of liquidity providers and/or the IMF. This, and most other features of the new arrangement, was not decided at Kyoto, with the Ministerial noting that the members had: "instructed the Deputies to carry out further indepth studies on the key elements of the multilateralization of the CMI including surveillance, reserve eligibility, size of commitment, borrowing quota and activation mechanism."

However, progress was slow. Those present at the 11th ASEAN+3 Finance Ministers' Meeting held in Madrid, Spain, in 2008, merely agreed that the total size of the reserves pool would be at least $\$ 80$ billion, and that 80 per cent of the amount would be contributed by the plus-3 countries (China, Japan, and Korea), with the rest provided by ASEAN countries. The implicit financial subordination of ASEAN to the plus-3 countries, especially China and Japan, which was unavoidable given relative economic strengths, was accepted. Given the asymmetric distribution of reserves across the region this distribution was understandable, though the $\$ 80$ billion figure was not. Finally, in the following year, the Joint Media Statement issued after the 12th ASEAN+3 Finance Ministers' Meeting in Bali, Indonesia on 3 May 2009 declared:

"On the Chiang Mai Initiative (CMI), we have reached agreement on all the main components of the CMIM, including the individual country's contribution, borrowing accessibility, and the surveillance mechanism. The agreed components of the CMIM, which is a framework of mutual assistance among ASEAN+3 countries, are consistent with its two core objectives: (i) to address short-term liquidity difficulties in the region and (ii) to supplement the existing international financial arrangements.

"...We agreed that an independent regional surveillance unit will be established as soon as possible to monitor and analyze regional economies and support CMIM decision-making....". 51

The understanding was that the total pool was to be $\$ 120$ billion, with 80 per cent contributed by the Plus 3 countries and the rest by ASEAN countries. As voting shares were linked to contributions, China (along with Hong Kong) was allotted \$38.4 billion in contributions, which

\footnotetext{
${ }^{50}$ Joint Ministerial Statement of the 10th ASEAN+3 Finance Ministers' Meeting, 5 May 2007, Kyoto, Japan, quoted in Sussangkarn (2010).

${ }^{51}$ The Joint Media Statement of the 12th ASEAN Plus Three Finance Ministers' Meeting, Bali, Indonesia, 3 May 2009, accessed at https://asean.org/the-joint-media-statement-of-the-12th-asean-plus-three-finance-ministersmeeting-bali-indonesia-3-may-2009/.
} 
equaled that of Japan. South Korea was given a smaller $\$ 19.2$ billion (Table 2). The equal voting shares of China (together with Hong Kong) and Japan clearly reflected a diplomatic compromise to convince each that the other will not dominate the arrangement. But with China alone (excluding Hong Kong) restricted to $\$ 34.2$ billion, Japan was given a sense of being the largest single contributing country.

Table 2: CMIM Contributions and Purchasing Multiples

\begin{tabular}{|c|c|c|c|c|c|c|}
\hline \multirow{4}{*}{ China } & \multicolumn{5}{|c|}{ Financial contribution } & \multirow{3}{*}{$\begin{array}{l}\begin{array}{l}\text { Purchasing } \\
\text { Multiple }\end{array} \\
0.5\end{array}$} \\
\hline & \multicolumn{3}{|c|}{ USD (billion) } & \multicolumn{2}{|c|}{$(\%)$} & \\
\hline & \multirow[t]{2}{*}{38.40} & $\begin{array}{l}\text { China } \\
\text { (Excluding Hong Kong) }\end{array}$ & 34.20 & \multirow[t]{2}{*}{32.00} & 28.50 & \\
\hline & & Hong Kong, China & 4.20 & & 3.50 & 2.5 \\
\hline Japan & & & 38.40 & & 32.00 & 0.5 \\
\hline Korea & & & 19.20 & & 16.00 & 1 \\
\hline Plus 3 & & & 96.00 & & 80.00 & - \\
\hline Indonesia & & & 4.77 & & 3.97 & 2.5 \\
\hline Thailand & & & 4.77 & & 3.97 & 2.5 \\
\hline Malaysia & & & 4.77 & & 3.97 & 2.5 \\
\hline Singapore & & & 4.77 & & 3.97 & 2.5 \\
\hline Philippines & & & 3.68 & & 3.07 & 2.5 \\
\hline Vietnam & & & 1.00 & & 0.83 & 5 \\
\hline Cambodia & & & 0.12 & & 0.10 & 5 \\
\hline Myanmar & & & 0.06 & & 0.05 & 5 \\
\hline Brunei & & & 0.03 & & 0.02 & 5 \\
\hline Lao PDR & & & 0.03 & & 0.02 & 5 \\
\hline ASEAN & & & 24.00 & & 20.00 & - \\
\hline Total & & & 120.00 & & 100.00 & - \\
\hline
\end{tabular}

- Hong Kong, China's purchasing is limited to IMF de-linked portion because Hong Kong,

China is not a member of the IMF

Source: Joint Press Release: The Establishment of the Chiang Mai Initiative

Multilateralization, December 28, 2009. Accessed at

https://www.boj.or.jp/en/announcements/release_2009/un0912d.htm/\#att.

As before, when faced with balance of payments difficulties, a country could swap its currency for US dollars through the facility. Each country's borrowing quota is based on its contribution multiplied by a country specific borrowing multiplier. The borrowing multiplier was set at 5 for Brunei Darussalam, Cambodia, Lao PDR, Myanmar, and Viet Nam, at 2.5 for Hong Kong, Indonesia, Malaysia, Singapore and Thailand, at 1 for Korea, and 0.5 for Japan and China.

Though the agreement provided for a regional surveillance mechanism, the IMF-link remained. For borrowing in excess of the IMF-delinked portion, amounting at first to 20 per cent of a country's borrowing quota, an agreement with the IMF was necessary even to set off the discussion that must end with a two-thirds majority vote for the loan to be approved. On the other hand, neither China nor Japan could independently veto a loan decision, if all other members joined hands (Grimes 2011). But subjecting any potential borrower who has won IMF approval to the uncertainty associated with this voting process would only discourage recourse to the CMIM.

At the 15th ASEAN+3 Finance Ministers and Central Bank Governors' Meeting held May 2012 at Manila, the Philippines, it was decided to modify the CMIM agreement to (i) double the total size of the CMIM from $\$ 120$ billion to $\$ 240$ billion; (ii) increase the IMF de-linked portion to 30 per cent; (iii) lengthen the maturity and supporting period for the IMF linked portion from 90 days to 1 year and from 2 years to 3 years, respectively, and those for 
the IMF de-linked portion from 90 days to 6 months and from 1 year to 2 years, respectively; and (iv) introduce a crisis prevention facility called the "CMIM Precautionary Line" (CMIMPL). ${ }^{52}$ The support facility to address emergency, short run liquidity shortages was named the CMIM Stability Facility (CMIM-SF). The CMIM-PL operates in parallel with the CMIM mechanism (now renamed the Stability Facility). While CMIM, which is the crisis resolution mechanism would require IMF clearance, the Precautionary Line, which is aimed at addressing medium term liquidity requirements and structural problems, was to be based on ex ante conditionality, or an assessment of the quality of a country's economic polices (without being subject to ex post performance targets). But given the policy inclination in these countries, "quality" would be defined as adherence to IMF-style policies and standards ${ }^{53}$ (Hyun and Paradise 2019).

\section{No real progress}

With hindsight we now know that nothing came of these regional cooperation efforts expressly aimed at addressing the vulnerabilities that stem from the enhanced and volatile flows of capital across borders after 2004. Three factors explain that failure. The first was the subordination of the regional agreement to the IMF, as a means of perpetuating the existing regional balance of power and of ensuring repayment, which subverted the regional effort. The second was the turn to the US Federal Reserve when offered an opportunity, to access dollar liquidity through swap arrangements which this institution can proliferate without limit, given its control over dollar issuance. The third is increasing acceptance of bilateral arrangements with one of the regional powers - Japan or China - to access dollar or regional currency liquidity.

\footnotetext{
52 "The Joint Statement of the 15th ASEAN+3 Finance Ministers and Central Bank Governors' Meeting" accessed at https://www.asean.org/wpcontent/uploads/images/archive/Joint\%20Media\%20Statement\%20of\%20the\%2015th\%20ASEAN3\%20Financ e\%20Ministers\%20and\%20Central\%20Bank\%20Governors\%20Meeting.pdf. See also Hyun and Paradise (2019).

53 This tendency has persisted in more recent developing country multilateral initiatives. Along with the creation of the New Development Bank, the BRICS summit at Fortaleza in July 2014 established a BRICS-controlled Contingent Reserve Arrangement (CRA) with committed resources of $\$ 100$ billion, defined as "a framework for the provision of support through liquidity and precautionary instruments in response to actual or potential shortterm balance of payments pressures". Article 5 in the treaty specifies a maximum borrowing limit for each member, which is a multiple of the financial commitment made by the member. Access to 30 per cent of this maximum (the delinked portion) is available to a member based only on the agreement of the 'Providing Parties'. The remaining 70 per cent (the IMF-linked portion) can be accessed in part or full only if, in addition to the agreement of the providing parties, the Requesting Party can provide evidence of "an on-track arrangement between the IMF and the Requesting Party that involves a commitment of the IMF to provide financing to the Requesting Party based on conditionality, and the compliance of the Requesting Party with the terms and conditions of the arrangement." The text of the treaty can be accessed at http://www.brics.utoronto.ca/docs/140715-treaty.html
} 


\begin{tabular}{|c|c|c|c|c|}
\hline & Indonesia & Korea & Thailand & Total \\
\hline 1997 support package (A) & 42.3 & 58.4 & 17.2 & 117.9 \\
\hline \multicolumn{5}{|l|}{ CMIM borrowing quota } \\
\hline \multicolumn{5}{|l|}{ With IMF link } \\
\hline Amount & 11.38 & 19.2 & 11.38 & 41.96 \\
\hline Percentage of A, inflation-adjusted & 20.56 & 25.12 & 50.56 & 27.20 \\
\hline \multicolumn{5}{|l|}{ Without IMF link } \\
\hline Amount & 2.276 & 3.84 & 2.276 & 8.392 \\
\hline Percentage of A, inflation-adjusted & 4.11 & 5.02 & 10.11 & 5.44 \\
\hline
\end{tabular}

Source: Cho 2011.

The effect of the IMF clause was visible during the 2008 financial crisis, which was a first major test of the use of the regional arrangement after 1997. No affected country resorted to borrowing under the CMI. This was because the sum that could be accessed by a country under the regional arrangement, without having to present an agreement with and certificate of compliance from the IMF, was relatively small (Table 3) (Cho 2011). This comes through from a comparison of what was available even under the CMIM with what was availed of by crisis hit countries during the 1997 crisis, ignoring the fact that the latter occurred much before the CMIM was agreed upon and before the post-2004 surge in capital flows. For example, if the CMIM swaps had been available to Thailand before the crisis in 1997, it would have been able to draw around $\$ 2.3$ billion (20 per cent of borrowing quota) without turning to the IMF for conditionality-linked assistance. That figure amounted to just above 13 per cent of Thailand's $\$ 17.2$ billion rescue package put together under IMF auspices in nominal terms, and a lower 10 per cent after adjusting for inflation. If the packages availed by the big three crisis-hit countries in 1997 are considered, IMF-delinked funding available from the CMIM quotas was $\$ 8.4$ billion in nominal terms, as compared with the aggregate IMF-led rescue packages for these countries of $\$ 117.9$ billion. That is just 5.4 per cent of the actual funding received, when adjusted for inflation. 


\begin{tabular}{|c|c|c|c|}
\hline & \multirow{2}{*}{ Reserve holdings } & \multicolumn{2}{|c|}{ CMIM contribution } \\
\hline & & Amount & Percentage of reserves \\
\hline China, including Hong Kong & $3,116.0$ & 38.4 & 1.2 \\
\hline Japan & $1,036.3$ & 38.4 & 3.7 \\
\hline Korea & 286.9 & 19.2 & 6.7 \\
\hline Plus 3 Subtotal & $4,439.2$ & 96.0 & 2.2 \\
\hline Indonesia & 90.0 & 4.552 & 5.1 \\
\hline Thailand & 165.7 & 4.552 & 2.7 \\
\hline Malaysia & 102.3 & 4.552 & 4.4 \\
\hline Singapore & 223.9 & 4.552 & 2.0 \\
\hline Philippines & 54.0 & 4.552 & 8.4 \\
\hline Vietnam* & 13.4 & 1 & 7.5 \\
\hline Cambodia & 3.1 & 0.12 & 3.9 \\
\hline Myanmar* & - & 0.06 & - \\
\hline Brunei* & 1.1 & 0.03 & 2.7 \\
\hline Lao* & 0.6 & 0.03 & 5.0 \\
\hline ASEAN subtotal & 653.5 & 24.0 & 3.7 \\
\hline Total & $5,092.7$ & 120.0 & 2.4 \\
\hline
\end{tabular}

Source: Cho (2011) based on IMF, International Financial Statistics; and APT, "Joint Ministerial Statement of the 13th ASEAN+3 Finance Ministers' Meeting." Data for Vietnam is as of the end of October 2010; for Brunei, November 2010; and for Lao, June 2010. No data is available for Myanmar.

This limited size of the CMIM kitty, especially its IMF-delinked portion, was not because of inadequate availability of reserves among the leading ASEAN+3 members. It was because the share of reserves contributed to the CMIM facility was extremely small (Table 4), with only 20 per cent of that small contribution being delinked from IMF conditionality. Thus, despite the reserves available in the region, the amount of money available under the Chiang Mai Initiative without IMF involvement was too small to make a significant difference. Countries, therefore, would prefer, if unavoidable, to deal directly with the IMF, since its conditionalities would have to be met in any case. Unless it was the case that resources available from the IMF and the private capital inflows that could be accessed once an arrangement with the IMF was sealed were inadequate, it did not make sense to turn to resources available under the CMI or 
CMIM. And even if they were, bilateral funding and swap arrangements may be an option open to some countries.

Once again, the factor that seems responsible for the CMIM not proving to be an alternative to balance of payments financing from the IMF or developed country sources is the political tension between the two major funders, China and Japan, and them and the rest. That kept the overall size of the regional kitty, and that part that was managed independent of the IMF, relatively small. With both of the regional powers seeking to enhance their influence, it was inevitable that they would like to be seen as directly supporting distressed nations through bilateral arrangements rather than doing so through an 'impersonal' organization. Reflecting the absence of full commitment to the CMIM, the contributions made by various countries remained with their central banks to be made available in the event of a crisis, though the size of the corpus or common liquidity pool available under CMIM was defined. The fund was made up of promises to pay. Further, as discussed earlier, the tensions also meant that neither of these major donors was in a position to ensure that the funds accessed by member countries would be put to proper use. Any attempt to bilaterally impose ex ante or ex post conditions on use of the resources would risk alienating the borrower and losing influence relative to the other major funding nation. In the event, borrowers could play one against the other and not do the needful to use the funds available to correct the problems that gave rise to the crisis in the first place.

A second consequence was that, for long, there was no regional monitoring agency ensuring adoption of appropriate policies by countries accessing the facility. Not trusting each other, the major donors continued the arrangement in which large volume borrowing from the facility required an IMF program, though a country was allowed to borrow up to 20 per cent (subsequently 30 per cent) of its quota without submitting to IMF conditionality. This meant that, when financing requirements were large, countries would choose to approach the IMF directly.

Some efforts have been underway since the launch of the facility to generate an autonomous system of monitoring, independent of the IMF. Initially there was a quasi-formal mechanism in the form of the Economic Review and Policy Dialogue initiative. When multilateralization was instituted, a special ASEAN+3 Macroeconomic Research Office (AMRO) was established. ${ }^{54}$ But delegation of framing program conditionality and enforcement to the IMF continued. Requiring an IMF program for funding defeated an important objective that motivated the Asian Monetary Fund proposal in 1997, of avoiding conditionality of a kind that militated against sustainable adjustment and implied burdensome austerity. The reasons for opting for a regional fund were defeated by the design of the CMI and its successor, the CMIM. The initiative had been subverted right from the start.

This was confirmed when the global financial crisis broke in 2008, and investors chose to book profits or cut losses and repatriate their dues to meet commitments at home. CMI member countries, though not at the epicenter of the crisis, faced significant shortages of foreign liquidity. Even a country like South Korea, that had accumulated large foreign reserves as insurance against a 1997-type crisis, was stressed because those reserves amounted to only around 60 per cent of the sum total of foreign holdings of South Korean equity, bonds and short-term debt. Even if not to the same degree, such stress was true of Indonesia and Singapore as well.

\footnotetext{
${ }^{54}$ The ASEAN+3 Macroeconomic Research Office (AMRO) was established as a regional macroeconomic surveillance unit in April 2011.
} 
However, the CMI proved inadequate to deal with the stress. Capital exit at that time saw countries go beyond the region for support. South Korea and Singapore borrowed from the US Federal Reserve and Indonesia from the World Bank and other lenders. The consequences of this were visible in the case of South Korea. At the end of 2008, though South Korea had \$201 billion of forex reserves, the ratio of its net exposure to footloose foreign capital amounted to 73.5 per cent of those reserves, making it vulnerable to dollar funding shortages. To quote Grimes (2011: 90): "The only East Asian economy that had a truly close brush with crisis in this period was South Korea in the fall of 2008. Despite accumulated foreign exchange reserves of approximately $\$ 200$ billion at the time, the Bank of Korea (BOK) became concerned about dollar liquidity in the banking system. The BOK acted swiftly to head off this threat by concluding a $\$ 30$ billion swap agreement with the U.S. Federal Reserve, which was announced on October 30." ${ }_{55}$ The Bank of Korea availed a total of $\$ 16.3$ billion, through five transactions in December 2008 and January 2009, all of which was provided to domestic financial institutions faced with a shortage of dollar liquidity (Hyun and Paradise 2019). This amounted to around 60 per cent of the BOK's emergency provision of foreign exchange to domestic financial institutions.

In 2008, the CMIM was not operational and South Korea could have only obtained $\$ 18.5$ billion by opting for the swap arrangements it had access to under the CMI. Moreover, of this sum, only $\$ 3.7$ billion could be accessed without being subject to an IMF program, given the 20 per cent limit on borrowing without an IMF agreement (Sussangkarn 2010). Given its experience with IMF conditionality and surveillance at the time of the 1997 crisis, South Korea was understandably not willing to take this option.

\section{Separate bilateral swap arrangements}

Moreover, some countries had access to bilateral swap arrangements with Japan and China, through which too they could access short term dollar liquidity without being subject to IMFstyle conditionality. South Korea, for example, had agreements with China and Japan (much smaller than with the US) between October and December 2008.

Other countries that went in for special financing during this period also preferred to go in for separate bilateral swap arrangements, with countries both within and outside the region. Singapore opted for swaps with the US and Japan; and Indonesia, which reportedly sought a swap arrangement with the US but was refused, opted for swaps with China and Japan and a $\$ 5.5$ billion financing facility from the World Bank, the Asian Development Bank (ADB), Australia and Japan (Kadogawa et al 2018). Needless to say, countries that could arrive at a swap arrangement with the US had access to substantial volumes of dollar liquidity, without being subject to IMF-style conditionality. ${ }^{56}$

Access to bilateral central bank swaps outside the CMI essentially meant that the CMI arrangement would prove completely ineffective, given its tie-in with an IMF agreement and IMF surveillance of the country concerned. So, though developments during the global

\footnotetext{
${ }^{55}$ Made conscious of the need for its support outside its conventional swap partners, the Fed established identical swap lines for Singapore, Brazil and Mexico. The choice of emerging markets was clearly influenced by the importance of these countries for US finance.

56 "The advantage of engaging in a bilateral swap arrangement (BSA) with the Federal Reserve is the signal it sends to the capital market. Even if emergency liquidity can be provided in Japanese yen or Chinese yuan, the genuine FX liquidity that can be readily used to reverse the direction of an attack on an Asian country's currency is the US dollar and only the US dollar as of now. The maximum amount of liquidity support of up to $\$ 23.5$ billion could have been retrieved by the Republic of Korea from the CMI in 2009; however, of such an amount, only $20 \%$ would have been disbursed without the Republic of Korea having had to negotiate with the IMF yet again." Hyun, S. and J. F. Paradise (2019).
} 
financial crisis of 2008 possibly prodded the member countries to finally agree on multilateralizing the CMI starting 2009, with a corpus of $\$ 120$ billion, this did not serve as the preferred window when faced with volatility. The fact remains that after three decades of the start of the ASA, regional currency swaps had not become the go to option for dealing with external financial vulnerability. This, however, was not true of swaps per se, but only of the ASEAN+3 arrangement, in which exercising the option amounted to accepting IMF conditionality and surveillance.

\section{Federal Reserve forex swaps}

Meanwhile, there is reason to believe that US presence through Federal Reserve swaps is likely to increase. This is because, with globalization, US banks and financial institutions are increasingly exposed abroad and foreign central banks and financial institutions have borrowed to invest in US Treasuries and US financial markets. Given that, a dollar liquidity shortage in foreign locations can lead to disturbances that have repercussions in US markets. Addressing that shortage in difficult times with swap arrangements is therefore in the interests of the US.

Not surprisingly, with greater global financial integration the role of swaps as a Fed instrument has changed over time and the use of the swap route by exploiting its unlimited ability to proliferate dollar liquidity has been aggressively deployed by the Fed in recent decades. While any two central banks can enter into swap arrangements, those between the Fed and other central banks partners have been central to the functioning of the international monetary system.

Thus, even while the ASEAN+3 countries were experimenting with setting up a regional swapcentered arrangement, the crises-induced extension of the US Fed's long-standing use of swaps offered an alternative US-driven source of dollar liquidity for countries in region. Being the source of global dollar liquidity, the Fed had the ability to extend generous access to dollars. Such access did not come with IMF-style conditionality and surveillance. The combination of volume, ease of access and absence of IMF intervention meant that this was seen as a superior alternative to the hybrid schemes involving regional cooperation and IMF dependence that the CMI and CMIM turned out to be.

This does mean that if a regional power, such as China or Japan, seeks to enhance its economic and political influence in the region, it must be willing to directly or indirectly deploy its dollar reserves to seal swap arrangements in the region. This obviously cannot be through a regional arrangement that imports US influence as a means of maintaining the regional power balance. The arrangements have to be bilateral. While, as discussed earlier, Japan has experimented with such bilateral swaps since the Miyazawa Initiative, in recent years China has been the country aggressively deploying this instrument - an issue we turn to later.

\section{Reserve accumulation as "defense mechanism"}

If in the aftermath of the 1997 and 2008 crises the Fed swap option did not overwhelm regional central banks, it was not only because of what was on offer from the Fed, but also because many Southeast Asia countries sought to build their own reserves and insulate themselves from crises. Table 5 lists countries according to the volume of reserves accumulated over the period 2001-19, together with the cumulative size of capital flows and the current account balance during these years. It should be clear that though China was a net recipient of cross-border capital flows over this period, its reserve accumulation (the largest in the group) was largely on account of the foreign exchange it earned through running current account surpluses. This was true of Japan as well, though capital outflows from Japan moderated the extent of its reserve accumulation during these years. Outside the region, a large country like India offers a strikingly different picture. It notched up a large cumulative current account deficit, but yet 
managed to record significant reserve accumulation because of large capital inflows. India had accumulated large foreign liabilities, which not only financed its current account deficits, but showed up as an increase in reserves (often accumulated through central bank purchases aimed at moderating upward pressure on the rupee resulting from large capital inflows). The reserves in essence were "borrowed".

\begin{tabular}{|l|r|r|r|}
\hline \multicolumn{4}{|l|}{ Table 5: Cumulative Reserve Accumulation and Cumulative Capital Flow (2001-19) (\$ bn) } \\
\hline & Capital Flows & Reserve Accumulation & Current Account \\
\hline China, P.R. & -956.94 & 3104.81 & 3387.91 \\
\hline Japan & 1962.74 & 886.03 & 2751.44 \\
\hline India & -950.29 & 427.97 & -519.84 \\
\hline S. Korea & 530.70 & 284.48 & 775.82 \\
\hline Hong Kong & 75.48 & 266.89 & 302.23 \\
\hline Singapore & 567.92 & 233.52 & 823.11 \\
\hline Thailand & 39.43 & 192.49 & 250.08 \\
\hline Indonesia & -258.20 & 116.88 & -132.37 \\
\hline Vietnam & -136.58 & 75.96 & 10.51 \\
\hline Malaysia & 151.55 & 68.28 & 335.59 \\
\hline Philippines & -21.84 & 62.19 & 59.07 \\
\hline Myanmar & -30.84 & 18.48 & -10.85 \\
\hline Cambodia & -29.64 & 11.00 & -21.17 \\
\hline Brunei & 27.30 & 2.68 & 67.68 \\
\hline Lao PDR & -19.55 & 0.12 & -11.50 \\
\hline
\end{tabular}

Note: Because of statistical discrepancies, including those arising from use of cumulative figures, the columns do not add up.

Source: Based on information from IMF, Balance of Payments Statistics Database.

\section{Footloose capital}

Another consequence of the fear of capital flight was an effort to curtail dependence on volatile capital flows, which reduced the probability of an unmanageable shortage of dollar liquidity. This is visible in trends in the ratio of net footloose capital (defined in a broad sense to cover the stock of net liabilities in portfolio equity, debt assets, and financial derivatives) to foreign exchange reserves excluding gold. In all countries being studied here, that ratio fell sharply or quite significantly after the 1997 crisis (Table 6). The drivers of that decline varied, however, across time and space. In some countries and some periods, especially immediately after the 1997 crisis, the decline was on account of a fall in capital inflows. In others, the fall was on account of a rise in reserves, or a combination of a fall in inflows and a rise in reserves. Moreover, the factors underlying the rise in reserves were different. In some cases, it was on account of current account surpluses generated by holding down domestic absorption and diverting production to exports. In others, such as India, it was on account of capital inflows exceeding current account financing requirements. 


\begin{tabular}{|c|c|c|c|c|c|c|c|c|c|c|c|}
\hline \multicolumn{12}{|c|}{ Table 6: Exposure to Footloose Capital (\%)* } \\
\hline & Thailand & Philippines & Myanmar & Malaysia & $\begin{array}{l}\text { Lao } \\
\text { PDR }\end{array}$ & Korea & Indonesia & India & China & Cambodia & Brunei \\
\hline 1997 & 399 & 580 & 4,766 & 261 & 1,999 & 441 & 810 & 397 & 38 & 222 & $-6,212$ \\
\hline 1998 & 330 & 483 & 3,862 & 159 & 2,080 & 220 & 639 & 361 & 6 & -23 & $-7,964$ \\
\hline 1999 & 260 & 360 & 4,615 & 158 & 2,347 & 194 & 598 & 307 & -12 & -30 & $-6,561$ \\
\hline 2000 & 200 & 358 & 5,454 & 139 & 1,705 & 121 & 486 & 268 & -44 & -19 & $-8,436$ \\
\hline 2001 & 164 & 353 & 2,983 & 136 & 1,894 & 124 & 464 & 227 & -18 & -34 & $-8,592$ \\
\hline 2002 & 126 & 358 & 2,494 & 127 & 1,570 & 116 & 398 & 165 & -16 & -28 & $-6,931$ \\
\hline 2003 & 125 & 376 & 2,125 & 117 & 1,115 & 114 & 377 & 140 & -2 & \begin{tabular}{l|l}
-7 \\
\end{tabular} & $-7,484$ \\
\hline 2004 & 105 & 370 & 1,751 & 103 & 1,212 & 102 & 392 & 137 & 6 & 3 & $-7,930$ \\
\hline 2005 & 98 & 281 & 1,473 & 95 & 1,269 & 137 & 352 & 171 & 5 & -5 & $-8,596$ \\
\hline 2006 & 78 & 240 & 878 & 87 & 962 & 137 & 307 & 174 & 6 & -7 & $-9,396$ \\
\hline 2007 & 66 & 197 & 316 & 88 & 703 & 154 & 272 & 193 & 6 & -32 & $-7,804$ \\
\hline 2008 & 37 & 151 & 248 & 60 & 818 & 136 & 262 & 154 & -9 & -9 & $-6,142$ \\
\hline 2009 & 38 & 141 & 156 & 70 & 985 & 137 & 274 & 196 & 4 & -42 & $-3,841$ \\
\hline 2010 & 57 & 140 & 156 & 93 & 850 & 148 & 250 & 208 & 7 & -62 & $-3,573$ \\
\hline 2011 & 59 & 122 & 92 & 86 & 952 & 140 & 234 & 189 & 8 & \begin{tabular}{|l|}
-71 \\
\end{tabular} & $-2,300$ \\
\hline 2012 & 81 & 139 & 106 & 97 & 962 & 144 & 252 & 227 & 7 & -66 & $-1,887$ \\
\hline 2013 & 72 & 131 & 48 & 106 & 1,277 & 129 & 268 & 231 & 12 & \begin{tabular}{l|l|}
-58 \\
\end{tabular} & $-1,998$ \\
\hline 2014 & 80 & 136 & 129 & 105 & 1,133 & 100 & 278 & 251 & 15 & -37 & $-2,044$ \\
\hline 2015 & 57 & 122 & 74 & 95 & 1,071 & 74 & 279 & 231 & 3 & -7 & $-2,216$ \\
\hline & & & & & & & & & & & \\
\hline
\end{tabular}

Source; Computed using dataset underlying Philip R. Lane and Gian Maria Milesi-Ferretti (2017).

\section{Revealing relationships}

Charts 16,17 and 18 track the relationship between cumulative reserve accumulation and the cumulative current account balance by country over three time periods: 1990-97 (which was prior to the Southeast Asia crisis), 1998-2007 (which was the period between Southeast Asia crisis and the Global Financial Crisis), and 2007-19 (which covers the post-GFC years of unconventional monetary policies that saw a huge increase in global liquidity). In the first of these periods, preceding the Southeast Asian crisis, the Chart excludes Japan, for which BPM6 data are available on the IMF website only from 1996. For the rest of the countries, we find that Singapore and China were clear outliers in the upper right quadrant, with large cumulative current account balances and significant or large cumulative reserve accumulation. All the other countries, especially the large Southeast Asian countries and India were located in the upper left quadrant with significant or large cumulative current account deficits and moderate reserve accumulation (funded clearly with capital inflows). 


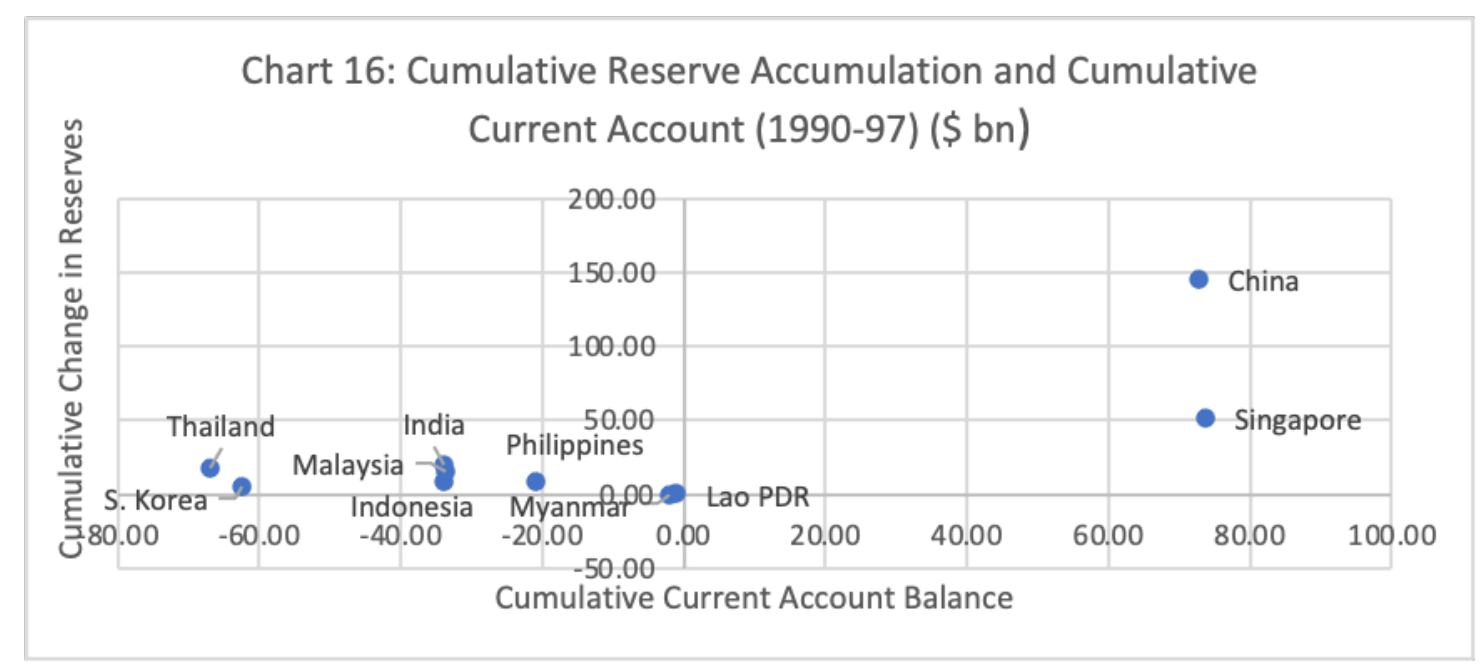

Source: Based on information from IMF, Balance of Payments Statistics Database.

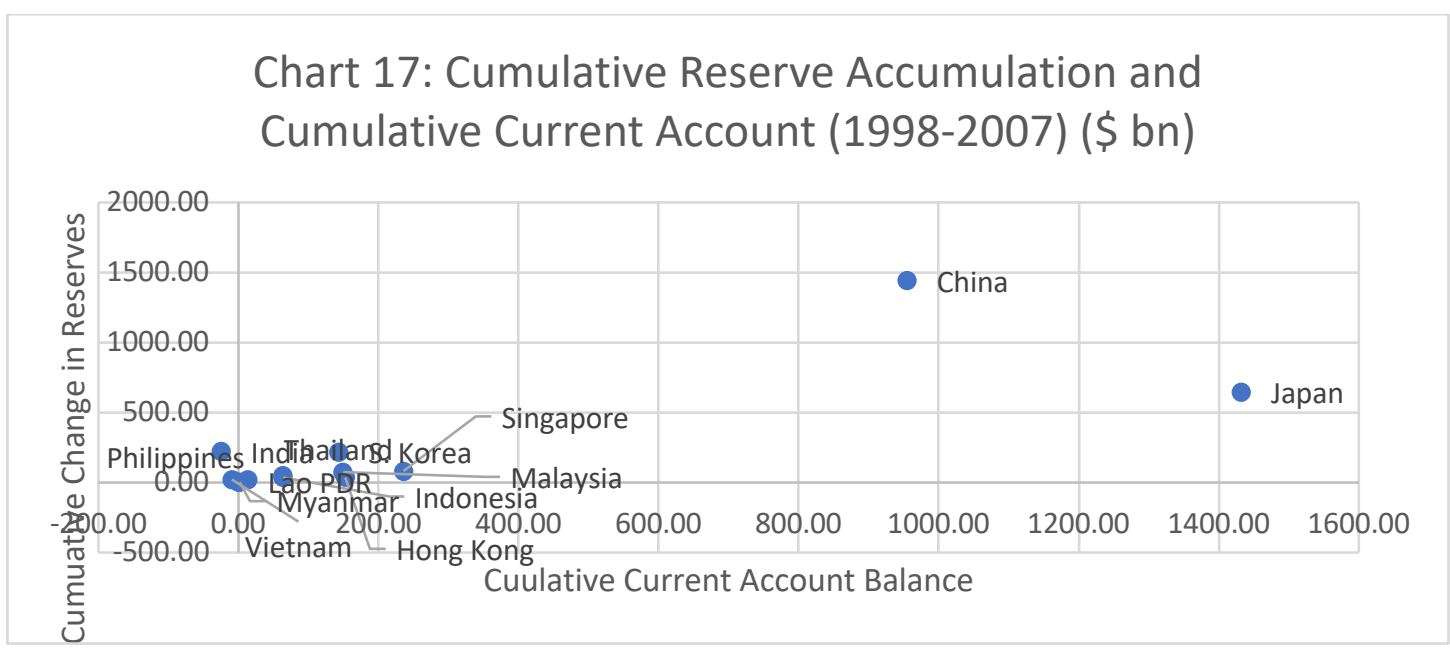

Source: Based on information from IMF, Balance of Payments Statistics Database.

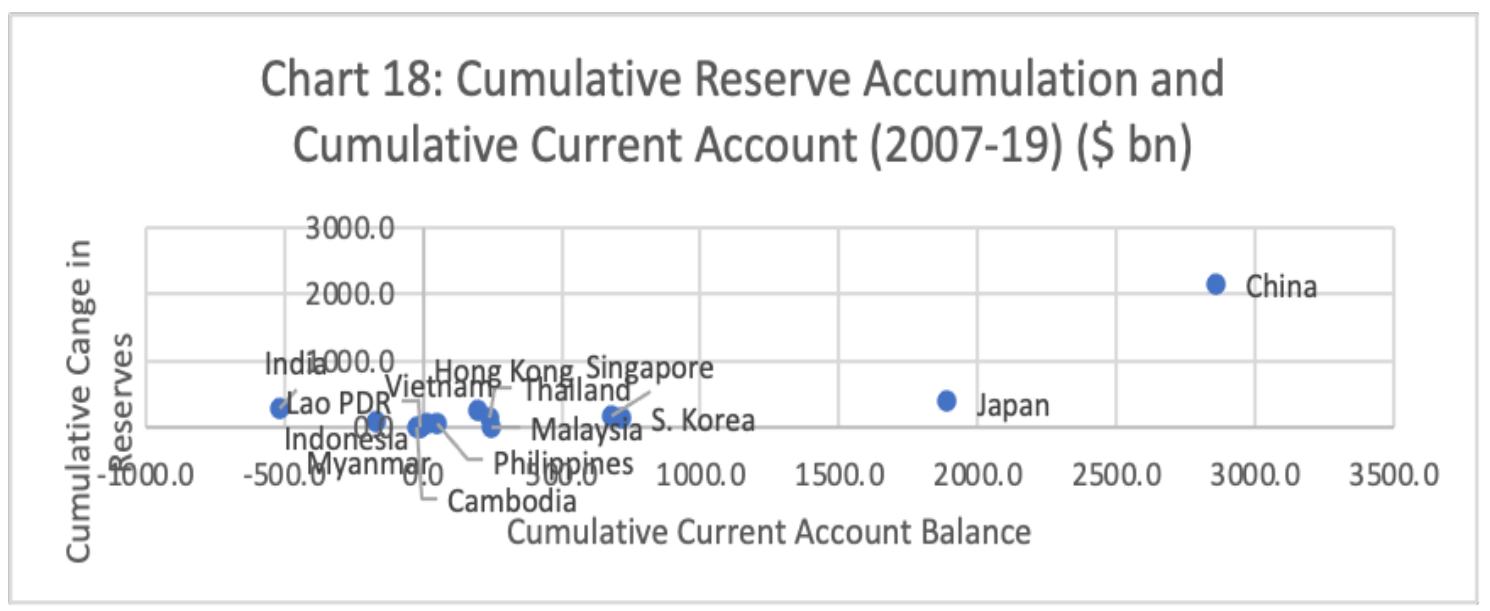

Source: Based on information from IMF, Balance of Payments Statistics Database. 
During the second period, the pattern of the scatter changes dramatically. As before, China was a clear outlier with large cumulative current account surpluses and reserve accumulation and Singapore was still in the upper right quadrant. Japan (now included) joined these two as a similar outlier. What changed, however, is that barring India, all the other big economies in the set being studied, which includes the Southeast Asian majors, moved from the upper left to the upper right quadrant with significant cumulative current account surpluses and substantial cumulative reserve accumulation, reflecting the pursuit of their "insurance strategy". ${ }^{57}$

This shift was accentuated during 2007-18 when, besides China and Japan remaining outliers, the larger Southeast Asian countries continued to record significant cumulative current account surpluses and accumulate larger reserves during the period, whereas India continued with its paradoxical combination of current account deficits and reserve increases (financed with capital inflows). It is in this period that Indonesia joined India as a country that recorded current account deficits, while still accumulating reserves. The Indonesian experience is reflective of the importance of primary product exports for the country. Given that importance, it benefited from the commodity price boom of the early 2000s and was adversely affected by the postGFC decline in commodity prices.$^{58}$ Seen in the light of those external influences, it is India's case that is unique among the set of countries under study.

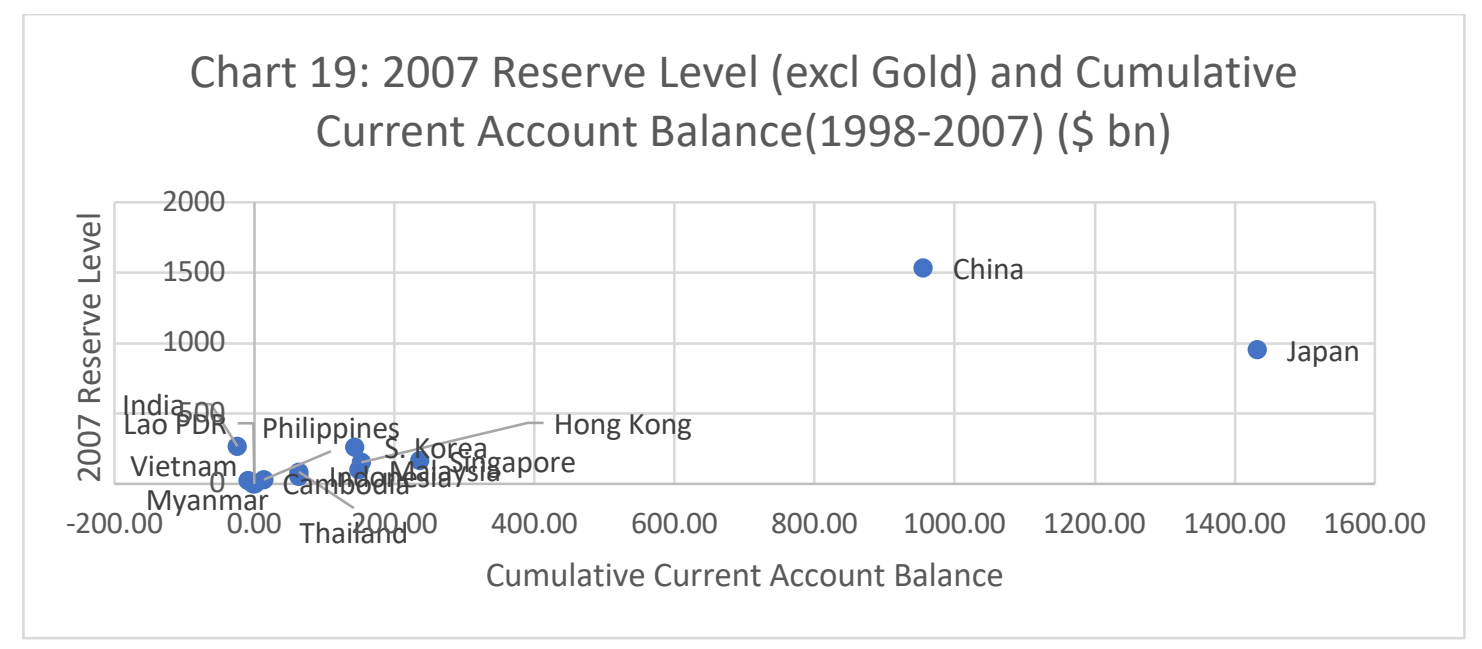

Source: Based on information from IMF, Balance of Payments Statistics Database.

\footnotetext{
${ }^{57}$ Note the difference in scale in the Y-axes of Charts 10 and 11.

${ }^{58}$ For the complex effects on the Indonesian economy of the commodity price boom and its end, see World Bank (2010) and Wihardja (2016).
} 


\section{Chart 20: 2019 Reserve Level (excl Gold) and Cumulative}

Current Account Balance(2007-19) (\$ bn)

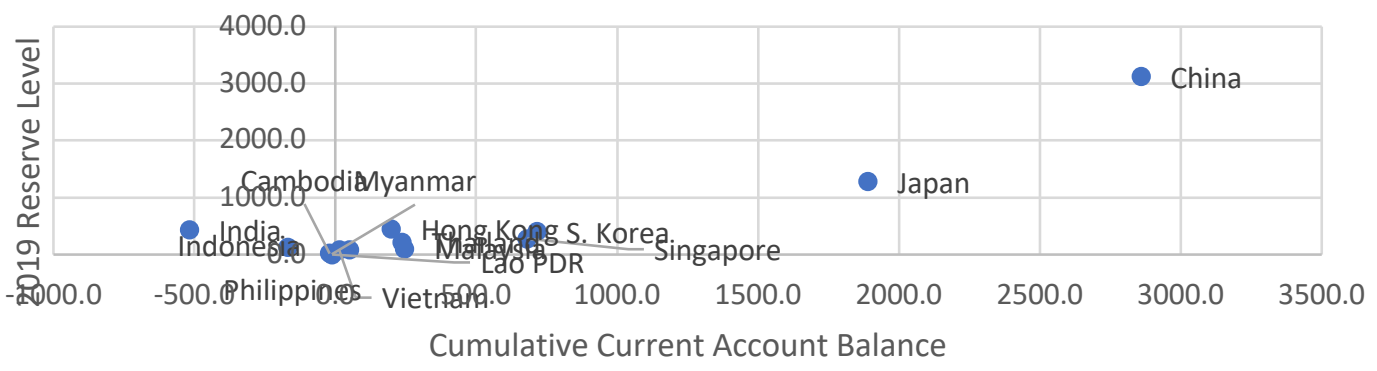

Source: Based on information from IMF, Balance of Payments Statistics Database.

Charts 19 and 20 relating the cumulative current account balances of countries during 19982007 and 2007-18 respectively with the aggregate level of reserves at the end of each of these periods, bring out the point starkly. In 2007, moderate levels of aggregate foreign currency reserves in major Southeast Asian countries were associated with significant cumulative current account balances. India was an exception with cumulative deficits and reasonable reserves. China and Japan were the ones with large volumes of free reserves. After 2018, Indonesia started recording cumulative deficits and India's deficits widened. Indonesia had a small reserve to show in 2018, whereas India had a figure comparable with some countries in Southeast Asia.

What is noteworthy is the cumulative capital inflow scenarios in these two periods (Charts 21 and 22). After 1997, most Southeast Asian countries, excepting South Korea, began recording net outflows of capital. South Korea was clearly receiving post-crisis foreign investment, including some engaged in takeovers at bargain prices. But the real recipients were China and India. After 2007, Korea too recorded significant net outflows of capital, and Indonesia joined India as a recipient. China remained a major recipient of foreign investment, not just direct but also portfolio investment, as some capital controls were relaxed. Japan was the major exporter of capital. But India was the only country in this group that relied on foreign capital inflows to finance both current account deficits and reserve accumulation.

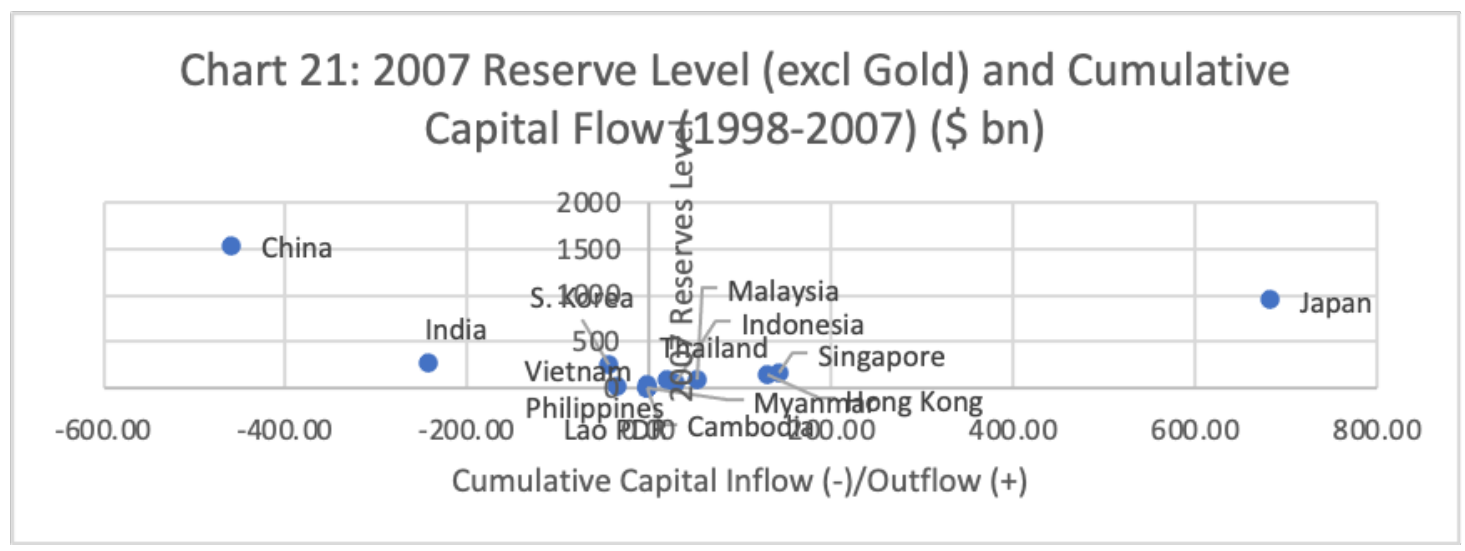

Source: Based on information from IMF, Balance of Payments Statistics Database. 


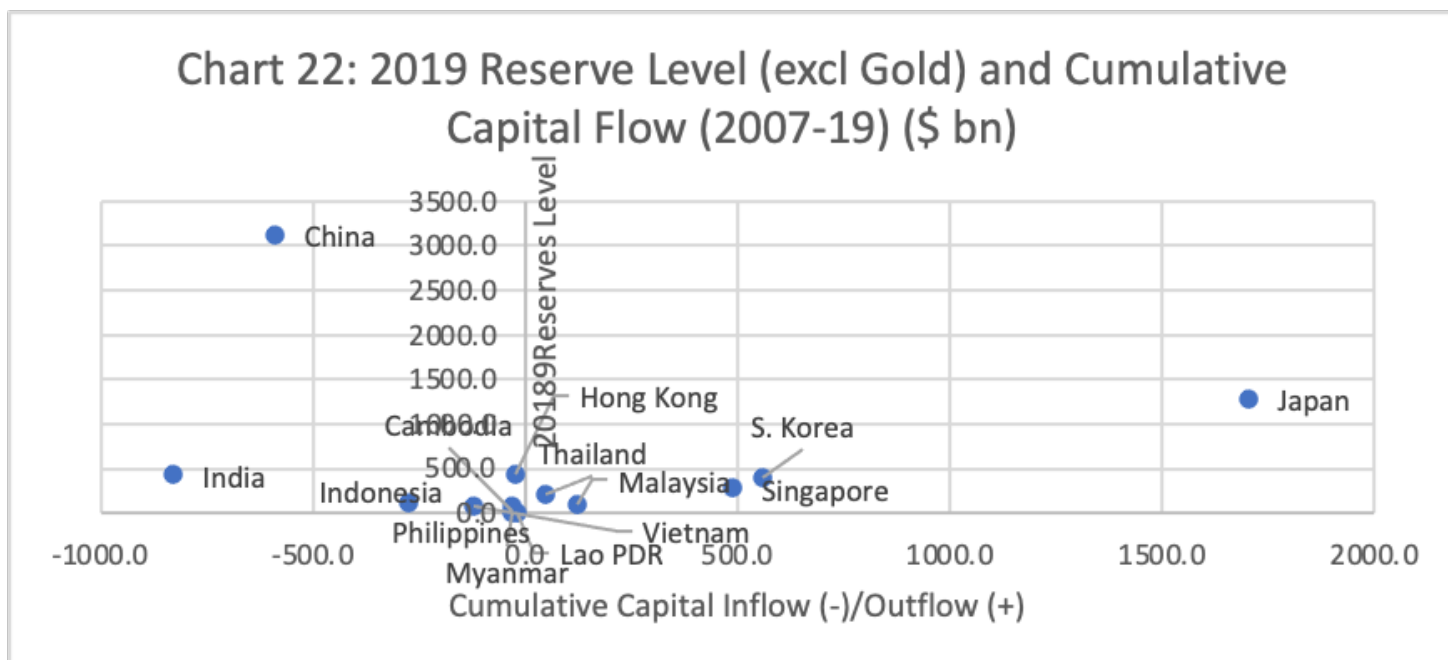

Source: Based on information from IMF, Balance of Payments Statistics Database.

The importance of current account surpluses in building reserves in Southeast Asia is a direct fall-out of the Southeast Asian financial crisis of 1997. On the one hand, the crisis and the austerity policies that were imposed through conditionalities associated with IMF balance of payments support depressed investment and led in time to import compression and an excess of savings over investment that delivered current account surpluses. On the other hand, hit hard by the sudden exit of capital, the balance of payments and currency crises that followed, and the recession that ensued, these countries responded by insuring themselves against recurrence by accumulating reserves as a cushion against capital flight. ${ }^{59}$ This cautionary stance continued even after the crisis had been tided over, resulting in a new normal of lower investment and growth when compared with the "miracle years" some of these economies had experienced. A slightly exceptional case is China which recorded current account surpluses associated with an excess of savings over investment, even while it registered very high levels of export driven investment. However, one country from within the ASEAN group (Indonesia) and India, that escaped the 1997 crisis, could not similarly absorb the lessons of the crisis, making them vulnerable.

The initial adjustment to the crisis varied significantly across countries, with an acceleration of liberalization in some (South Korea and Thailand) and greater intervention in others (Malaysia). The immediate response tended to be significantly affected by the extent of IMF intervention, which forced a deflationary fiscal response. Overall, the crisis countries experienced a macroeconomic shift in terms of a large divergence between savings and investment rates. The East and Southeast Asian region generally had very high savings ratesbetween 30 and 45 percent. The period subsequent to the financial crisis saw a continuation or an increase in these already high rates, especially in the "crisis" countries. However, investment rates (that is, the share of investment in GDP) plummeted in all these countries, with the sole exception of Thailand where it first fell and then rose again, albeit not reaching its earlier peak.

Therefore, 1997 marked a clear break from the earlier trend, when, typically, domestic investment rates were higher than savings rates, and the balance was met by an inflow of

\footnotetext{
59 "When taking a probing look into the current situation in ASEAN+3, it becomes clear that they have individually accumulated massive FX reserves as a self-insurance to control volatile capital flows, which usually result in financial instability in emerging markets." Hyun and Paradise (2019: 14).
} 
foreign capital. The latter is in fact what one would expect in a developing country, because it is generally supposed that developing countries are characterized by a shortage of investible resources. Therefore, economic openness, especially to foreign investment, is designed to allow foreign resources to add to domestic savings in order to generate a higher rate of investment than would be possible using only domestic resources. After the crisis, from 1998 onward, these economies actually became more "open" in policy terms, especially with respect to rules regarding foreign investment. Nevertheless, after 1998 at least some among these countries stopped being net recipients of foreign savings and instead showed the opposite tendency of net resource outflow, as domestic savings were higher than investment. This meant that there was a process of squeezing out savings from the population as a whole but not investing it within the economy to ensure future growth. Instead, these savings were used to acquire assets abroad or add to the external reserves of the central banks, which were typically held in liquid and very safe assets abroad (such as US Treasury Bills) that delivered low yields. Whether consciously or not, this not only reduced demand for foreign exchange within these countries but created a buffer in the form of reserves that could be used whenever there was a surge in demand for dollar liquidity (Chandrasekhar and Ghosh 2013).

A very large role in the reduction of aggregate investment was played by fiscal policies of governments in these countries, which increased their own savings and cut down on fiscal deficits or increased fiscal surpluses. Even though the financial crisis in these countries was essentially brought on by private profligacy in a financially liberalized environment, the aftermath of the financial crises created an environment of excessive caution on the part of governments. The pressure was on governments to keep budget deficits under control by reducing spending. As a result, governments in these countries did not spend as much as could be easily sustained by the economy, to ensure better conditions for the people, or to encourage more sustainable growth and generate more employment.

So, the major cause for this apparent excess of capital, which was then exported to the United States and other developed countries, was the adoption of deflationary policies on the part of these governments, which suppressed domestic consumption and investment. One obvious reason for this was the fear of a repeat of the large and destabilizing movements of speculative capital that were such a strong feature of the financial crisis of 1997-1998. The idea was to guard against the possibility of such potentially damaging capital flight by building up substantial foreign exchange reserves, even when they could involve large fiscal losses.

The message from these experiences needs summarizing. There are two positive roles that capital inflows can, in principle, play in developing countries. One is a long term role where capital flows that create capacities to earn foreign exchange allow countries to invest more than their domestic savings rates warrant, leading to an acceleration of the pace of development. The second is a short term one where when countries are faced with balance of payments difficulties and dollar funding shortages, capital inflows provide the liquidity to tide over these difficulties without forcing the countries concerned into adopting deflationary measures. This is what the CMI and CMIM sought to achieve in the ASEAN+3.

Conversely, capital inflows, especially if prone to sudden stops and exits, can play a negative role and have adverse consequences. It can render countries vulnerable to boom-bust capital flow cycles, with busts leading to adoption of austerity policies to compress income growth and demand so as to reduce imports and divert some commodities away from domestic consumption to exports. Such 'adjustment policies', if persisted with, can result in the medium and long term in a low growth scenario where investment falls short of savings, slowing growth 
and through that means ensuring current account surpluses and reserve accumulation that insure the country against crises.

What appears to be the case in the ASEAN is that, while the smaller economies did not attract capital flows of a magnitude that gave them policy flexibility and high growth, the most successful became victims of the boom-bust cycle that precipitated a 1997-style crisis and took them down a trajectory of low growth aimed at insuring them against recurrence of a similar crisis.

The smaller economies such as Myanmar, Lao PDR, and even others like the Philippines and Indonesia are still vulnerable. In some of them, even small fluctuations may require resort to balance of payments support. Elsewhere, a source of vulnerability is the high dependence of many of the ASEAN economies on exports. As noted, post the 1997 crisis, some among these economies have substantially reduced their dependence on foreign capital inflows. But the burden of legacy capital from the past does mean that the capital account remains open and the danger of capital flight remains. The use of deflation to record current account surpluses and accumulate reserves in the leading ASEAN members has meant that small fluctuations in trade and capital flows are not destabilzsing. But when big shocks like the 2008 GFC occur, the damage can be substantial.

From the supply side, the vulnerabilities facing developing countries and the so-called emerging markets have only increased since the early 2000s, and especially after the global financial crisis of 2008. From a period in which the fundamental question was whether there would be enough global liquidity, in the form of 'hard' currency to finance the balance of payments of deficit countries, the world has moved to a context in which the problem is one of excess global liquidity. That tendency only intensified after the 2008 crisis, when the infusion of cheap liquidity to address the banking crisis in the developed world, followed by rounds of "quantitative easing" to reverse the downturn, resulted in a surge in capital flows to developing countries. However, whenever there is any uncertainty, including over the persistence with quantitative easing and over interest rate movements, there is a real danger of capital flow reversals that can have damaging balance of payments and currency instability effects.

A typical example of reversal on speculative grounds was the "taper tantrum" in the second half of 2013, when the mere fear that quantitative easing would end and interest rates would rise set off capital flight from emerging markets in Asia. In fact, the fear that the tapering of quantitative easing and the raising of interest rates may destabilize the global financial system, besides the reality that there had been no robust recovery before the Covid-19 induced crisis, had made it difficult for central banks to retreat from what are euphemistically termed "unconventional monetary policies". The Covid-induced crisis has in fact seen a dramatic expansion of the liquidity being infused into the system to support firms and financial institutions and revive demand and growth. This has subjected many developing countries to episodes of surges of capital inflow as investors search for yield, increasing in the process the vulnerability of these countries to boom-bust cycles.

Given this history and current circumstances, a regional swap arrangement that provides access to short term dollar liquidity can, in principle, be of help to smooth fluctuations resulting from these varying levels and kinds of external vulnerability the ASEAN countries face. However, as we have seen, in practice, these arrangements have not been of much help for a host of reasons.

There are three conclusions that emerge from this discussion. First, the vulnerability arising from a combination of enhanced cross-border capital flows and open capital accounts in 
emerging and developing economies has not gone away. Second, the reason why this vulnerability has not triggered crises of the kind experienced in 1997 is because governments have curtailed expenditure and reduced growth to generate current account surpluses and reduce dependence on external capital. However, some Asian countries like India are indeed vulnerable. Third, while the challenge of finding a way of increasing access to dollar liquidity without increasing external vulnerability remains, the regional multilateral cooperation effort to find a US- and IMF-independent solution to the problem seems unworkable for a host of reasons. This does create an environment where countries may be willing to accept bilateral solutions, if available, that allow for a return of dynamism in the region.

\section{Changing geopolitical and economic context}

Meanwhile, in the period since the 1997 Southeast Asian financial crisis and through the subsequent GFC of 2008 and Covid-induced crisis of 2020, the economic power balance in the Asian region has been changing significantly. While Japan remains a balance of payments surplus country with large foreign exchange reserves, it has been considerably weakened, not having ever fully recovered from the 1990 financial crisis that engulfed it and having seen its competitiveness in world markets erode. On the other hand, China has seen its position hugely strengthened having consolidated its position as the manufacturing hub of the world, strengthened its position as leader in many frontline technologies and accumulated a huge cache of foreign currency reserves.

In this changing environment, China has adopted a two-track strategy. On the political and military fronts, it has turned more aggressive, not only in Hong Kong and vis-à-vis Taiwan, but with a range of Asian countries stretching from the small Himalayan kingdom Bhutan to Australia, India, Japan, the Philippines and Vietnam. These moves seem to be designed to signal its intent to play a more weighty and even dominant role regionally and globally. On the other hand, economically it has adopted a more collaborative multipronged program aimed at increasing its presence and influence in the region and outside. ${ }^{60}$ One aspect of that program is an effort to promote new multilateral financing alternatives, that revive, in new forms, the idea of an Asian Monetary Fund, with China's role in these ventures being substantial or dominant. The second is to shape bilateral relationships involving flows of dollar liquidity in multiple forms - grants, credit for large infrastructural projects, foreign investment and central bank swap arrangements. The third is to participate in regional trade agreements that involves opening its own markets to the rest of Asia, but ensures, in return, an important and changed presence for China in regional value chains. A recent study from the Council on Foreign Relations (Blackwill and Zelikow 2021: 8) elaborates the view that sensing a weakening of the United States, besides Japan, China is seeking to replace the US "as the most important and influential nation in the Indo-Pacific region". If that was an aspiration earlier, they argue, "it has become under Xi the engine of most of China's day-to-day foreign policies."

\section{Multilateral Development Finance Initiatives}

Among the financing initiatives that China has supported or promoted, are the two multilateral banks geared to financing countries in the South in general, and Asia in particular, in which China has a strong presence or a position of control: the New Development Bank (NDB) and the Asian Infrastructure Investment Bank (AIIB) respectively. Both were launched in 2014. The New Development Bank was the outcome of discussions within the BRICS group of countries (Brazil, Russia, India, China and South Africa) that led up to the decision to launch

\footnotetext{
${ }^{60}$ Amyx (2005) argues that, after 2000, the primary driver of regional financial initiatives in Asia was China's
} proactive stance vis-à-vis regional cooperation. 
the Bank at their Fortaleza Summit in July 2014. With authorized capital of $\$ 100$ billion, and initial subscribed capital of $\$ 50$ billion, the bank's founding partners were the countries in the BRICS grouping (Brazil, Russia, India, China and South Africa). These five countries, which share equally the paid-up capital in the form of actual equity ( $\$ 10$ billion) ${ }^{61}$ and guarantees ( $\$ 40$ billion), will remain dominant in perpetuity with their aggregate shareholding never falling below 55 per cent. Though established as far back as 1944, the capital base of the IBRD (the core lending arm of the World Bank) was at the time of the formation of the NDB only $\$ 190$ billion of which only $\$ 36.7$ billion was available as actual equity, the rest being "callable capital" that countries have committed to provide when called upon to do so. So even at inception the NDB seemed significant in size compared to rivals still controlled by the developed industrial countries.

The AIIB, with headquarters in Beijing, was formally launched at a meeting of 21 Asian nations held in October 2014. With an authorized capital base of $\$ 100$ billion (of which $\$ 50$ billion was contributed by China), ${ }^{62}$ the AIIB as a start-up compared well with the Asian Development Bank with around $\$ 160$ billion of capital and the World Bank with around $\$ 220$ billion. Unlike the NDB, where promoter developing countries had equal shares in equity and voting power, China dominated the AIIB, holding 26.65 per cent of total votes as of June 2018, as compared with India and Russia that followed with 6.66 per cent and 6.04 per cent.

While expressly aimed at addressing the shortage of long-term capital for investment in crucial infrastructural areas and capital-intensive industries essential for development, these financing initiatives also play on the disillusionment of developing countries with the governance structure of and the kind of lending and the conditionalities associated with the Bretton Woods institutions and the leading regional development banks (Chin and Gallagher 2019).

The question remains whether the NDB would emerge as a real alternative to the IMF and the World Bank, which the Asian Monetary Fund proposed by Japan promised to be. There are clear signals that the NDB's lending is to be focused on large infrastructural projects that are seen as central to the development effort. Both cash-strapped developing country governments and the private sector are unable or unwilling to fully fund the lumpy investments involved in these long-gestation projects, making the role of development financing institutions crucial to development. An infrastructural focus has therefore been a characteristic feature of many of the currently existing multilateral development finance institutions as well. So, if the NDB is to be different from the World Bank or regional development banks like the Asian Development Bank, the difference would have to be reflected in the terms on which large loans are provided. Inasmuch as the institution has been established by a set of emerging nations that do not exercise hegemonic power in the international economy, it is possible that lending behavior could reflect such differences, which possibly accounts for the discomfort of the currently dominant institutions.

However, the NDB is fundamentally not detached from the global financial system. Being a bank, even if a specialized one, it must ensure its own commercial viability. And it must do so when a large part of the resources it lends would be mobilized from the market. While guarantees from the governments of its shareholding countries would improve the institution's rating and reduce its borrowing costs, those costs will have to be borne. So, any form of developmentally-oriented lending that does not yield a return adequate to cover costs and

${ }^{61}$ Of which 80 per cent is callable and 20 per cent to be paid in seven instalments (Wang 2019).

${ }^{62}$ China has promised to increase its contribution to $\$ 100$ billion, if needed. 
deliver at least a nominal profit will be ruled out. There is only so much an institution whose activities are constrained by market realities can do.

Above all, from the point of view of this discussion, despite having China and India as members of the initiative, the NDB was not an Asian institution with an Asian focus in its lending. So, it cannot serve as a hub for regional financial cooperation. Given these features of the more multilaterally controlled NDB, the significant initiative from a regional development point of view may be the AIIB, led by China with focus on Asia.

Initially, viewed as another global multilateral bank, the AIIB proposal appeared to be a bit of a non-starter. When the AIIB was formally established on October 24, 2014, there were only 20 countries that had agreed to sign in as founding members. The list did not include the US, UK and countries in Europe, and Japan, South Korea and Indonesia in Asia. It included a bunch of central Asian republics, a few countries from West Asia and members of the Association of Southeast Asian Nations, excluding Indonesia. India was among the biggest of non-Chinese founding members. This limited participation was despite the fact that Beijing had put out an open invitation to countries to join the board of the new initiative, and many like Australia, Indonesia and South Korea had expressed an interest in the beginning. Something or someone had dampened that interest, leading to the no-shows in October and the disinterest immediately thereafter.

However, matters changed hugely between October and April 2015, with many countries that had expressed skepticism or said they would "wait and watch", changing their minds and joining the AIIB as members, with a rush of applications as the deadline for founding membership approached. The tally of approved members rose from 57 at founding to 103 as of January 2021. This was significant because of a concerted US campaign against the bank. The US refused to join on the grounds that the governance of the bank would not meet 'required' standards, with China having a veto on decisions and international safeguards relating to the environmental, labor and human rights impacts of the projects financed not being met. But it did not stop there. It campaigned vigorously to keep its allies, principally the UK, European countries like Germany, France and Italy, and Asia-Pacific partners such as Japan, South Korea and Australia out of the AIIB.

However, unlike in the case of the Asian Monetary Fund, the US was faced with isolation and abject failure. Not only did the UK decide to suffer rebuke from the US, which it normally faithfully supports as a strategic partner, and become a founding member, but many other US allies, like Germany, South Korea, and Australia, also opted to register as founding members. In the end, the list of founding members included all countries of importance in Asia, except for Japan, and the UK, Germany, France, Italy and Australia, among others.

The US, which criticized the UK for its "constant accommodation" of China when it decided to become a founding member, has reason to fear the Chinese move to establish the AIIB. The financial architecture that came out of the Bretton Woods conference, and evolved from there, had the US firmly in control. Efforts to even marginally shift the distribution of quotas and voting power in the IMF face stiff resistance. The US retains the right to nominate the leadership of the World Bank, and the head of the IMF is always European. In Asia, Japan, a faithful and subordinate ally of the US, has been given control over the Asian Development Bank (ADB). In sum, the US and its allies had tied up things in their favor, and more or less froze it thus.

This would have been partly justifiable during the era when the G7 countries were the main sources of global surpluses that had to be recycled to deficit countries largely through the 
bilateral and multilateral 'aid' network. They leveraged that power to influence the national policies of dependent governments and shape a world they desired. However, it is no longer true that these countries are the source of the world's surpluses. The United States is the world's largest debtor. Capital flows are dominantly private, and official flows are a falling fraction of the total. In the new environment, the success of the G7 lay in its ability to retain most of the international financial centers and control most of the financial institutions that mediate global capital flows. But those flows originate, in large measure, as surpluses that countries like China accumulate and then invest either in dollar denominated US assets or in institutions that recycle surpluses to developing country recipients. Despite these changes in financial flows and the shifts in economic power they reflected, history and military might allow the US to retain its dominance over the global architecture and the dollar its supremacy.

The AIIB is perhaps one way in which China is calling this bluff. It clearly is an alternative to the ADB and the World Bank, with a voting structure that is vastly different with a bias in China's favor. China combines this with a host of other initiatives. Soon after the creation of the AIIB was announced, President Xi Jinping announced the creation of a Silk Road Infrastructure Fund, to which China has contributed $\$ 40$ billion and RMB 100 billion by way of capital. The Silk Road Fund too has a mandate to finance infrastructural projects that help "break the connectivity bottleneck" in the Silk Road Economic Belt and along the 21st Century Maritime Silk Road that are China's focus. Finally, China has also mooted a plan to establish a Development Bank of the Shanghai Cooperation Organization, which had China, Kazakhstan, Kyrgyzstan, Russia, Tajikistan, and Uzbekistan as its original members, and India and Pakistan joining in 2017. Here too China is expected to contribute the bulk of the capital, and the bank would serve as a vehicle to strengthen its investments in central Asia.

Five years after its launch the AIIB had only gone part of the way in realizing its promise. According to Dow Jones,$^{63}$ at the end of September 2020, AIIB's assets stood at $\$ 30.78$ billion and that of the NDB at $\$ 19.32$ billion. That is still way short of ADB's asset holding of $\$ 250.8$ billion and combined assets of the Word Bank, International Development Association and International Finance Corporation at $\$ 600$ billion. But in itself the record at the end of 5 years is significant.

Moreover, China combines the flows through multilateral institutions it jointly or singly controls with direct lending from its policy banks (especially the China Development Bank and Exim Bank), other financial institutions and state-owned entities. According to a data set collated by the Global Development Policy Center of Boston University, between 2008 and 2019 , loans contracted by the two main Chinese policy banks engaged in overseas lending to 858 projects worldwide totaled $\$ 462$ billion, almost equal to lending by the World Bank (of $\$ 467$ billion) over the same period. Together with all other flows, this makes China a major source of development finance. (Ray and Simmons 2020).

\section{Local Currency Swaps}

A completely different element of China's effort to emerge as a financing hub for developing countries in general, and those in Asia in particular is the network of local currency central bank swap arrangements that the People's Bank of China (PBoC) has established after the global financial crisis of 2008 - a less highlighted instrument that has contributed to China's growing global influence in developing countries worldwide. These bilateral swap arrangements (BSAs), denominated in RMB and the currency of the relevant partner central

\footnotetext{
${ }^{63}$ https://blinks.bloomberg.com/news/stories/QLJ4UG0799MO
} 
bank, allow the latter to access RMB liquidity for short periods at relatively low rates of interest, in return for its own currency as implicit collateral.

Between January 2009 and January 2020, the PBoC entered into such arrangements with 41 countries (Table 7). Most of these were put in place between 2009 and 2016 (Chart 23). Normally valid for a three-year period, many such arrangements have been repeatedly renewed, with the number of active agreements peaking at 33 in 2016 and standing at 27 by the end of 2019 (Chart 24). Despite the slight decline in the number of active arrangements between end2016 and end-2019, the total authorized value of such arrangements (or the maximum liquidity that can be availed through them) has been relatively stable, averaging RMB 3,333 billion between 2015 and 2019.

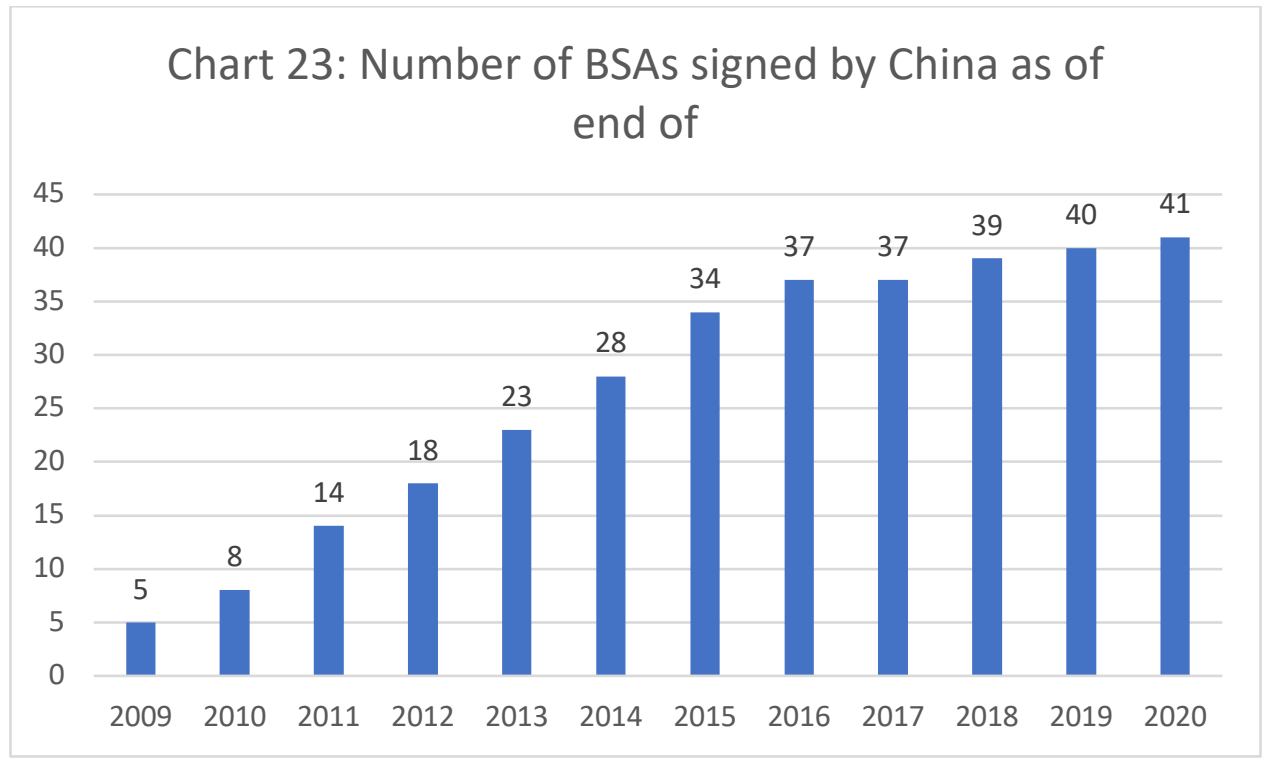

Source: Compiled using data collected from sources mentioned in Table 7.

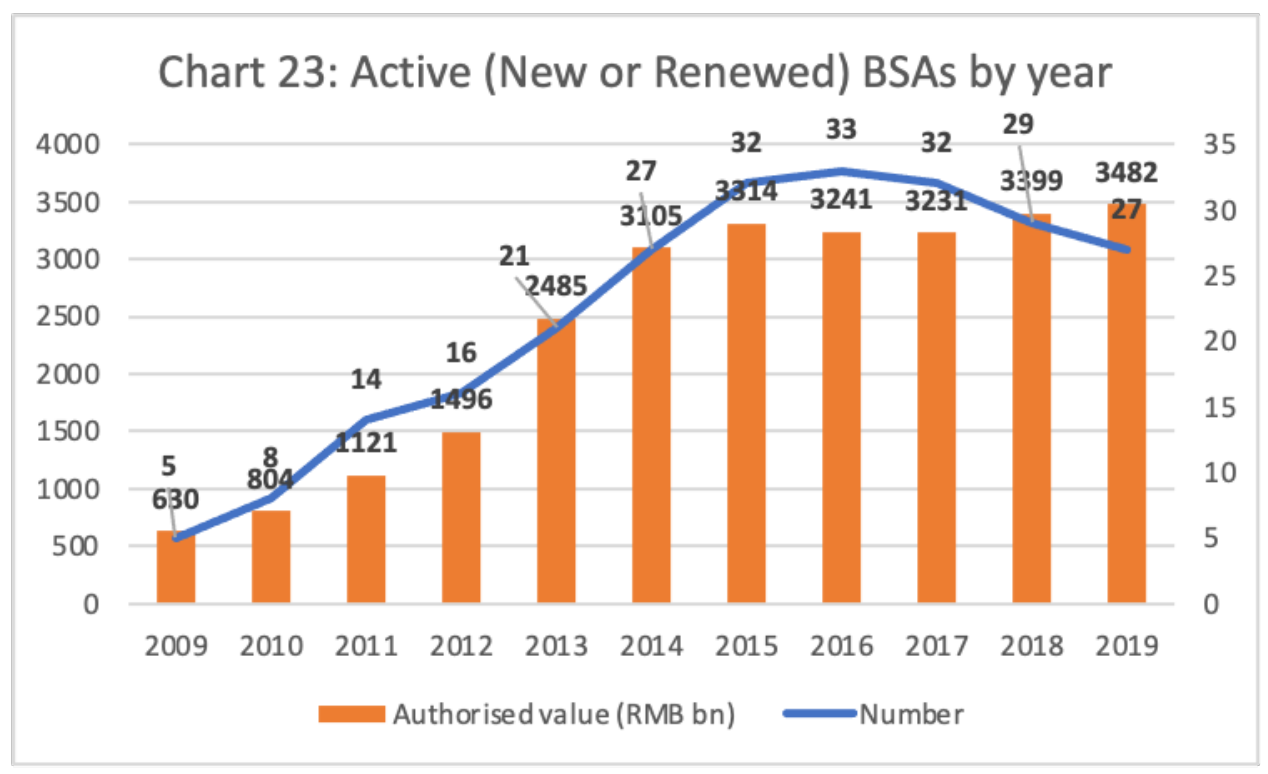

Source: Compiled using data collected from sources mentioned in Table 7. 
As discussed earlier, under a swap arrangement, while the borrowing central bank has access to the foreign currency liquidity line, it can lend it to institutions and agents in its own jurisdiction that face shortages of the relevant foreign currency, in this case the RMB. In principle, access to swap-mediated liquidity in RMB allows the recipient country to temporarily finance any deficit in current account transactions with China or meet any commitments arising out of financial or capital account transactions with that country. Given the importance of China as a provider of goods and a source of investments and credit to developing countries worldwide, and its effort to internationalize the RMB by designating an increasing share of those transactions in RMB instead of dollars, these swaps suit both China and its partners. ${ }^{64}$

For partner countries, the higher is the share of RMB denoted transactions, and the greater the availability of RMB credit and swap lines, the larger their leeway in using available dollar earnings and reserves to settle transactions with other countries. They can also, as Argentina and Pakistan did, use, or showcase their ability to use, the RMB accessed through the swap line, to acquire dollars and shore up their dollar reserves to meet commitments to third parties (McDowell 2019). For China, on the other hand, the swap line is an instrument that encourages partners to increase reliance on Chinese goods and RMB loans to buy them, enhancing thereby its economic influence, as well as furthering the goal of internationalizing the RMB and establishing it as an alternative reserve currency. ${ }^{65}$ Between 2009 and 2016 the RMB, which was non-existent as a currency in which global foreign reserves were held, carved out a small but significant share of 2 per cent (Bajaj and Reis 2020). Such developments played a role in prodding the IMF to recognize the RMB as a freely usable currency in 2016 and include it as the fifth currency along with the dollar, the euro, the yen, and the pound, in the Special Drawing Rights (SDR) basket with a weight of 10.9 per cent. They simultaneously served as a source of support for developing countries, including strategically placed, foreign exchange-starved neighbors like Sri Lanka and Pakistan. ${ }^{66}$

But this has imposed a burden on China. The normal perception is that a swap arrangement is relatively riskless for the lender central bank. Since the exchange rate is the same in both the spot and forward transactions through which currencies are exchanged, if the transaction goes through, there is no exchange rate risk borne by the source central bank. But if for some reason

\footnotetext{
${ }^{64}$ Garcia-Herero and Xia (2013) find that distance, size, trade engagement and the presence of FTAs influences the choice of countries with which China establishes a swap arrangement, supporting the argument that it was encouraging RMB settlement as part of its effort to internationalize the currency. They also find that China was willing to choose countries with such characteristics even if they had a history of default and operated with relatively closed capital accounts. Liao and McDowell (2015) argue that "both de facto trade interdependence and de jure economic integration via PTAs and BITs increase the probability of BSA cooperation between China and partners." See also Fang et al (2017).

${ }^{65}$ Bajaj and Reis (2020) suggest that, as happened with the dollar between 1910 and 1925, the Chinese government and the People's Bank of China are using schemes of trade settlement in RMB and establishment of RMB swaps as means of realizing the objective of internationalizing the currency and winning it reserve currency status. Interestingly, it has been suggested that Japan's advocacy of the AMF was also seen as motivated by its desire to internationalize the yen (Narine 2003). Eichengreen and Lombardi (2017) find that there is empirical evidence to support views that the RMB can potentially serve as a reserve currency globally or as one in the Asian region but argue that it is too early to tell which one would finally hold.

${ }^{66}$ McDowell (2019) argues that BSAs in which China is the lender to developing countries is a form of financial statecraft in which financial and monetary capabilities are leveraged to achieve foreign policy ends. While this may be true, the argument underestimates the role of these arrangements in supporting China's increasing global economic presence. Moreover, as Broz, Zhang and Wang (2020) emphasize, the willingness of developing countries to take up China's offers to establish bilateral swap lines was in no small measure due to their disillusionment with an international financial order led by the US that has subjected them to instability, crises, and IMF programs and conditionality.
} 
the borrowing central bank is unable to mobilize the currency of the source central bank to complete the forward transaction, the lender bank is left with collateral in the form of the currency of the borrowing country. In the circumstances, that currency is likely to have lost value relative to the exchange rate at which the swap was executed, resulting in losses for the lending partner.

This residual risk has influenced the swaps that other central banks have been willing to enter into. Though a large number of such bilateral arrangements are now in place globally, involving a wide range of central banks, till recently the US Federal Reserve was the principal source of liquidity delivered through bilateral swap arrangements, given the dominance of dollar denominated transactions in trading and financial settlements. However, the Fed has been very selective about the central banks with which it has signed swap agreements, clearly influenced by its perceptions of where the activation of such arrangements will be relatively riskless. Even at the height of the 2008 crisis, for example, besides the Bank of Canada, Bank of England, the European Central Bank, the Bank of Japan, and the Swiss National Bank, which are safe bets and with which the Fed had swap arrangements in the past, it chose to extend the net only to cover a set of developed country central banks in Sweden, Denmark, Norway, Australia, New Zealand, South Korea and Singapore, and only two developing country central banks in Brazil and Mexico. Moreover, indirectly providing foreign commercial banks access to dollar liquidity ensured that investors in dollar assets from these countries, unable to replenish capital borrowed to make those investments, did not withdraw and disrupt US financial markets.

As the list of countries in Table 7 makes clear, this is not the principle that the $\mathrm{PBoC}$ has adopted. It has entered into swap arrangements with countries that have a record of balance of payments stress. And often the arrangements were put in place when the country concerned was actually stressed. It is, of course, true that this was not purely the result of Chinese altruism. Rather, being a rising power jostling for space in the international order, and a dominant position in Asia, China seems willing to take the risk of loss to increase its economic presence and strengthen the role of its currency. That helps developing countries, which have largely been left out of the group covered by the Fed's dollar-liquidity swap system. 


\begin{tabular}{|c|c|c|}
\hline Countries & $\begin{array}{l}\text { Date of 1st } \\
\text { agreement }\end{array}$ & Initial Authorized Value (RMB bn) \\
\hline Hong Kong & Jan-09 & 200 \\
\hline Malaysia & Feb-09 & 80 \\
\hline Indonesia & Mar-09 & 100 \\
\hline Argentina & Apr-09 & 70 \\
\hline Korea & Apr-09 & 180 \\
\hline Belarus & Mar-10 & 20 \\
\hline Iceland & Jun-10 & 3.5 \\
\hline Singapore & Jul-10 & 150 \\
\hline New Zealand & Apr-11 & 25 \\
\hline Uzbekistan & Apr-11 & 0.7 \\
\hline Mongolia & May-11 & 5 \\
\hline Kazakhstan & Jun-11 & 7 \\
\hline Thailand & Dec-11 & 70 \\
\hline Pakistan & Dec-11 & 10 \\
\hline UAE & Jan-12 & 35 \\
\hline Turkey & Feb-12 & 12 \\
\hline Australia & Mar-12 & 200 \\
\hline Ukraine & Jun-12 & 15 \\
\hline Brazil & Mar-13 & 190 \\
\hline UK & Jun-13 & 350 \\
\hline Hungary & Sep-13 & 10 \\
\hline Albania & Sep-13 & 2 \\
\hline Eurozone & Oct-13 & 350 \\
\hline Switzerland & Jul-14 & 150 \\
\hline
\end{tabular}




\begin{tabular}{|l|l|l|}
\hline Sri Lanka & Sep-14 & 10 \\
\hline Russia & Oct-14 & 150 \\
\hline Qatar & Nov-14 & 35 \\
\hline Canada & Nov-14 & 200 \\
\hline Suriname & Mar-15 & 1 \\
\hline Armenia & Mar-15 & 1 \\
\hline South Africa & Apr-15 & 30 \\
\hline Chile & May-15 & 22 \\
\hline Tajikistan & Sep-15 & 3.0 \\
\hline Georgia & Sep-15 & n.a. \\
\hline Morocco & May-16 & 10 \\
\hline Serbia & Jun-16 & 1.5 \\
\hline Egypt & Dec-16 & 18 \\
\hline Nigeria & May-18 & 15 \\
\hline Japan & Oct-18 & 200 \\
\hline Macao & Dec-19 & 30 \\
\hline Laos & Jan-20 & n.a. \\
\hline Source: Updated version using press releases of the People's Bank of China \\
\hline in Direction générale du Trésor (French Treasury) (2018), Trésor- \\
\hline Nono No
\end{tabular}

It does not take much to recognize in all these moves an effort on the part of China to leverage its foreign exchange surpluses (which has been in excess of $\$ 3.8$ trillion for some time) to advance its economic and strategic interests in the region. This decision to take control of the eventual deployment of its surpluses seems inevitable. What is remarkable, however, is the focus on infrastructure. This is an area where the deficit is huge globally and in Asia. Infrastructural investment is not only central to growth but also for realizing the post-2015 social and sustainable development goals.

Governments that have almost all resorted to fiscal contraction because of the fears of financial crises precipitated by inflation and balance of payments deficits, have largely withdrawn from infrastructural funding. The private sector is not able to enter without government financial support directly or through public-private partnerships (PPPs), which defeats the purpose of 
bringing in the private sector. The PPP framework, which was much touted earlier, has been recognized to be a failure.

Coming into a context like this with large volumes of infrastructural funding gives China a strategic advantage. Countries desperately looking for infrastructural finance want to be in the game. Others that have seen capacities for producing equipment and intermediates for infrastructure lying unutilized do not want to be outsiders. So 'political' objections to the AIIB, influenced by a US that can offer little in return for support, have been quickly dropped.

From China's point of view the benefits are manifold. Chinese companies will be able to sell their goods and services to support the infrastructure push in the region. The infrastructure created will help China by improving access to markets, raw materials and new locations for cost-competitive production (given rising costs at home). And, above all there are the influence and strategic gains that it would garner as an emerging global power.

\section{Belt and Road Initiative}

Parallel to this formal intervention in the form of the AIIB, President Xi Jinping formally launched the Belt and Road initiative (BRI) in 2013, the coverage and constitution of which is nebulous. Global responses to the initiative have varied from dismissal on grounds that it is more hype than a matter of substance, to fear that it reflects Rising China's bid for economic territory and, finally, to moves to be in on the game, and benefit in ways varying from profits to accelerated development.

The ill-defined nature of the BRI partly stems from the fact that there is no official listing of all projects that fall in its ambit, making it difficult to separate projects that are merely part of China's longer-term push to establish a presence abroad from those that are elements of the specific design of this initiative. Moreover, projects can be financed in multiple ways: Chinese investment overseas, concessional aid or grants from the Chinese government, lending abroad on commercial terms by the Chinese government, the China Development Bank or other Chinese financial institutions, and finally, financing by other lenders or investors, such as multilateral financial institutions, host country governments, and non-Chinese public or private sector players. According to one source quoted by the Financial Times (Hornby 2019), Chinese institutional finance for BRI projects was routed through the Export Import Bank of China in 171 cases, the China Development Bank in 78 cases, the Industrial and Commercial Bank of China in 45, the Bank of China in 24, the China Construction Bank in 11, the New Development Bank in 6, the Silk Road Fund in 4 and a few others in 19. None of these institutions lend to or invest only in BRI projects. Even China-controlled or influenced Asian Infrastructure Investment Fund (AIIB) and the New Development Bank (NDB) lend considerable sums to India, for example, which is not a BRI-member country. This makes assessment of the size of the BRI in financial terms difficult, since it requires making a projectby-project assessment and then arriving at an aggregate.

This combination of the absence of a clear list of projects and the use of a broad set of financing sources makes any estimate of the current and future size of the BRI a guestimate. The Council on Foreign Relations estimates that by early 2020 China had spent an estimated $\$ 200$ billion on BRI projects (Chatzky and McBride 2020). Take any one indicator of possible BRI presence, such as a filtered set of Chinese overseas investments in BRI member countries tracked by the American Enterprise Institute (AEI), and the impression could be that the initiative is still small (Joy-Perez and Scissors 2018). Thus, in a little short of five years since its launch in 2013, the AEI estimates that 75 BRI member countries accounted for less than 25 per cent of total outward Chinese investments, or around $\$ 150$ billion. That is not insubstantial, 
but by no means overwhelmingly large. But then AEI notes, if Chinese overseas construction contracts, or contracts for Chinese construction and engineering firms are considered, the BRI investment figure over the same period rises to over $\$ 250$ billion. And, though that is the impression often created, Chinese firms alone are not likely to be the beneficiaries of construction contracts for projects that are identifiably BRI-related ${ }^{67}$ So, investments in projects under BRI could have exceeded $\$ 250$ billion in that five-year period.

Speculation is rife, therefore, not just on how far BRI has gone, but on how much further it will go, defining China's global presence and influence in the future. The evidence does suggest that capital flight and falling reserves have slowed Chinese foreign investment in recent years (Scissors 2020). President Xi Jinping has said that China alone will invest \$1 trillion in BRIrelated ventures. So, allowing for funding from multiple sources, the BRI roll-out over the next decade can be phenomenal. This has caught the world's attention. The real success of the second Belt and Road forum was evidence that China is now acquiring new partners for the BRI, who are willing to serve either as host countries for projects or as collaborators making investments or offering credit. This also seems to be the objective of China's pitch, and it has made all the right noises and done the right things.

To start with, China had to clear the air regarding accusations that it is combining in the BRI a search for economic territory with unscrupulous profiteering. It had to assuage fears that an instance like the Hambantota Port, which it acquired from the Sri Lankan government (with a $\$ 1.12$ billion investment for an 85 per cent equity share) on a 99-year lease because Sri Lanka was hard put to service the debt that financed the project, was not the norm. The acquisition, along with large tracts of land in the neighborhood of the port, it was argued, marked the successful completion of China's play to take control of a strategic port that would serve military rather than economic goals. The counterargument that China was only helping out to prevent default on a loan that financed a project which was not properly appraised by the Sri Lankan government was seen as a ruse. However, there is evidence that instances like Hambantota are more exceptions than the rule. Deborah Brautigam reports that out of more than 3,000 projects financed by China that she and other researchers have tracked, Hambantota was the only one that has been used as evidence of Chinese financing getting countries into a debt trap that serves China's strategic interests (Brautigam 2019). China is now making an effort to convey the message that the Hambantota experience was an exception rather than the rule to a growing number of partners.

Moreover, China now argues, it would start making its own assessment, following best practices, of the viability and sustainability of a project before providing support. In particular, it would try and ensure that projects and governments are not trapped in debt because they join the BRI, by 'objectively' assessing their debt problems and debt servicing capabilities. In reality, China has gone out of its way to help out countries that face debt servicing problems because of their participation in the BRI. In instances where debt-stressed countries are on the verge of default, China has been willing to restructure the debt in ways that reduced the debt burden.

There are other cases like the East Coast Rail Link project in Malaysia, that was negotiated when Najib Razak was the Prime Minister, in which the allegations are that the costs of the project were inflated and that China was complicit in the corruption that explained why the

\footnotetext{
${ }^{67}$ According to Klein and Pettis (2020), BRI projects financed with Chinese credit can, by generating new demand for Chinese exports of manufactured and construction, externalize the costs of rebalancing involving reduction of its excessively high investment levels. BRI countries can serve as a partial replacement for loss of traditional markets in the US and Europe.
} 
then Malaysian leader pushed ahead with an investment that was not viable. On those grounds, the subsequent government under Mahathir put the project on hold. Here too China displayed exceptional diplomacy, reducing by nearly a third the price for building the railway, while cutting the length of a close to 700-kilometere line by just 40 kilometers (Zhou 2019). These moves are a prelude to give new shape to the BRI.

The second BRI Forum ${ }^{68}$ reflected the directions in which China wants to take the BRI in its reformed avatar. It wants more partners, is willing to share a degree of control and is now willing to be professional and somewhat more transparent in evaluation, choice and implementation of projects. The evidence is that this new charm offensive is working. The number of participants in the forum rose from less than 30 to close to 40 between the first and the second versions. Countries in Europe, led by Italy, were considering joining or had already joined the BRI with the hope of benefiting in what are bad times for them, angering President Trump. And in what was a coup, a Brexit-confused UK decided to jump on as well, sending Chancellor of the exchequer Philip Hammond to the forum (Pickard 2019), clearly with the aim of mending economic relations between the two countries. An earlier Hammond visit, had to be called off after defense secretary Gavin Williamson muddied the waters by announcing that Britain would send a new aircraft carrier to the Pacific - a move Beijing saw as the use of "gunboat diplomacy". Hammond's visit was preceded by a leak of news that the UK had given security clearance to involve China's Huawei Technologies in its $5 \mathrm{G}$ roll-out. That decision, controversial among many OECD members who claim Huawei is a Chinese government intelligence front, was seen as a concession, in return for which the UK wanted a role for UK firms, especially from the city, in the lucrative financing deals that will accompany the promised acceleration of the BRI.

The real issue is whether with this "opening up" of the BRI, China will lose control and, therefore, influence, transforming an initiative that was seen as sinister into a benign development financing agenda. There are, however, as yet no signs of such a turn. China is still in "ideological" control, despite the concessions it is making. Some of those concessions would protect its own exposure. Moreover, China's interests seem to define the structure of the nebulous BRI. The initiative which is now seen as consisting of "Six Corridors, Six Roads", clearly has China as its central hub, creating as it unfolds a widening sphere of Chinese influence, with Chinese design, but multilateral participation and financing that make every Chinese dollar travel that much farther from its point of view.

\section{RCEP and China}

As part of its economic diplomacy, China has also managed to find itself a place as a partner in the Regional Comprehensive Economic Partnership (RCEP) agreement among 15 countries in the Asia-Pacific signed in late 2020 (Harding and Reed 2020). Commentators and observers woke up in the middle of a pandemic to express surprise and exude a sense of uncertainty at the deal being signed. Surprise, perhaps because China was a part of the agreement, despite the unrelenting discussion about its expansionist ambitions in the region. The allegedly aggressive regional power now sits with historical and more recent rivals varying from Japan and Australia to South Korea and Vietnam at a table that would be the site for discussions on wider and increased institutionalized economic cooperation and integration in the Asia-Pacific.

The uncertainty stems from a lack of clarity about how much China would benefit from the new arrangement, which India refused to join, and the US was not invited to participate in as

\footnotetext{
${ }^{68}$ See http://www.beltandroadforum.org/english/.
} 
an outsider that could manage the power balance within the club. As a trade promoting arrangement, the RCEP is no game changer. It largely integrates a whole host of trade agreements that were already in place between different subsets of the 15 that came together in this. The Economist reported that of the \$2.3 trillion in merchandise trade between the RCEP15 in 2019 , more than 80 per cent was already covered by pre-existing agreements. ${ }^{69}$ Moreover, other than reducing tariffs from already low levels and harmonizing clauses relating to different aspects of trade in the different agreements that rule in the region, the new deal does not make much advance in areas considered crucial to a neoliberal partnership such as foreign investment regulations, labor codes, environmental norms, intellectual property rights, state subsidies, and public procurement.

But other aspects of the RCEP agreement and this lighter version of a trade partnership possibly serve China's interests. For the first time, the agreement brings together with equal trading rights three regional heavyweights - Japan, China and South Korea-relations among which have been fraught. Along with the 11 other signatories these countries account for close to a third of global population, output and trade. With rules of origin for commodities to be eligible for reduced tariffs harmonized and kept relatively loose, this is a 'common market' of considerable size and significance that China now has freer access to.

Being a key hub in regional value chains and of the "Asian export platform", China can benefit not only from easier flows of intermediates and components, but enhanced access to a market that is set to grow faster than those elsewhere in the world. That China will play a greater role in that market was flagged by India's decision to withdraw from the discussions, on the grounds that it was not allowed what it argued were crucial safeguards for its domestic players from likely competition from cheap Chinese products. Moreover, it only suits China that a range of issues other than trade per se that matter to an economic partnership have been left open. As of now, China is reluctant to accept relatively strict multilateral norms in areas like intellectual property rights, implicit subsidies and environmental protection. So, it may not have been able to join the arrangement if the latter included clauses of the kind that are present in the other partnership arrangements centered around Asia, such as the Comprehensive and Progressive Trans-Pacific Partnership or CPTPP - the evolved form of the TPP that President Trump walked away from saying it would hurt America and its workers. On the other hand, as and when China would like clearer guidelines in an area like foreign investment regulation, it now has the right to raise the issue at an appropriate time. This could prove crucial since the evidence is that China is approaching that stage in its development where, as happened in the case of Japan and South Korea much earlier, it would lose competitiveness in low-end, labor intensive manufacturing. Labor costs are rising and countries are taking retaliatory action against what they see as "unfair competition" from China. This may warrant shifting some manufacturing facilities run by Chinese firms from the home country to foreign locations, which would call for friendly investment policies. China gains today and has partially insured itself against loss of those benefits in the future.

This change for the better in China's trading position in Asia, at a time when it is being acted against in markets elsewhere, enhances its position as a regional power, stemming from the BRI, the establishment of the New Development Bank and the Asian Infrastructure Investment Bank, and the RMB swap lines it has put in place.

69 “Who gains from RCEP, Asia's new trade pact?", The Economist, November 21, 2020 edition accessed at https://www .economist.com/finance-and-economics/2020/11/19/who-gains-from-rcep-asias-new-trade-pact. 
The RCEP is significant not only because it supports this multi-pronged Chinese push to regional and global big power status, but also because it does so without the presence of the United States and India, which share the objective of wanting to counter China's rise. While the United States did not have the option of being part of the RCEP, its decision under Trump to walk out of the TPP has diminished its influence over economic policy making in the region. India, on the other hand, did have the option of being a part of RCEP, but chose to withdraw on the grounds that it would adversely affect national economic interests. Being deprived of a share in India's market would hurt China. But the opportunity to extend China's regional influence without having India as an ally of the US interfering in that project may be more than adequate recompense.

\section{Concluding remarks}

In sum, China's growing influence in the region, which goes beyond East Asia, is driven by a multi-pronged (bilateral and multilateral) effort, with central bank swaps being only one instrument in the effort to shape a regional compact. But all of these are independent of the CMIM. In fact, China's new lines of approach do reduce the likelihood of the CMIM finally emerging as the preferred regional financial safety net, culminating a process that started with the idea of an Asian Monetary Fund. They also open up the possibility of China succeeding where Japan failed, by emerging as a regional leader and a bulwark against US influence in the region. That could well come to pass, unless, by deciding to back its quest for greater influence with territorial demands and military might, China jeopardizes its long term effort at regional economic dominance. What seems clear, however, is that the prospects for the primacy of an ASEAN+3 financial cooperation effort seem remote. The persistence of US hegemony over Japan and continuing geopolitical tensions in the Asian region imply that efforts at regional cooperation, warranted by financial integration and the volatile and whimsical nature of financial flows, would remain ineffective. Bilateral arrangements, especially between a rising China and countries in the region may be the means of diluting the domination of the US and the IMF. But given the complexities of politics and history, whether China would succeed in ensuring that outcome, which a previously dominant Japan did not, is yet uncertain. 


\section{References}

Akyuz, Yilmaz (2017), The Asian Financial Crisis: Lessons Learned and Unlearned, Policy Brief No. 42, July, Geneva: South Centre, available at https://www.southcentre.int/wpcontent/uploads/2017/07/PB42_The-Asian-Financial-Crisis-Lessons-Learned-andUnlearned_EN.pdf.

Amyx, J.A. (2002), "Moving beyond bilateralism? Japan and the Asian Monetary Fund", Pacific Economic Papers, no. 331. https://openresearchrepository.anu.edu.au/bitstream/1885/40431/3/pep-331.pdf.

Amyx, Jennifer (2005), "What Motivates Regional Financial Cooperation in East Asia Today?", Asia Pacific Issues, No 76, February, available at https://www .eastwestcenter.org/system/tdf/private/api076.pdf?file=1\&type=node \&id=32049.

Bahaj, Saleem and Ricardo Reis (2018), Central bank swap lines, Staff Working Paper No. 741, Bank of England 27 July, accessed at https://www.bankofengland.co.uk/workingpaper/2018/central-bank-swap-lines.

Bahaj, Saleem and Ricardo Reis (2020), Jumpstarting an international currency, Staff Working Paper No. 874, Bank of England 12 June, accessed at https://www.bankofengland.co.uk/working-paper/2020/jumpstarting-an-internationalcurrency.

Blackwill, Robert D. and Philip Zelikow (2021), The United States, China and Taiwan: A Strategy to Prevent War, Council Special Report No. 90, New York: Council on Foreign Relations.

Bordo, Michael D., Owen F. Humpage and Anna J. Schwartz, The Evolution of the Federal Reserve Swap Lines Since 1962, Working Paper 20755, National Bureau of Economic Research, December, accessed at http://www.nber.org/papers/w20755.

Borio, Claudio, Robert McCauley< Patrick McGuire and Vladyslav Sushko (2016), "Covered Interest Parity Lost: Understanding the Cross-currency Basis”, BIS Quarterly Review, September.

Brautigam, Deborah (2019), "Misdiagnosing the Chinese Infrastructure Push", The American Interest, April 4, accessed at https://www.the-americaninterest.com/2019/04/04/misdiagnosing-the-chinese-infrastructure-push/.

Broz, J. Lawrence, Zhiwen Zhang and Gaoyang Wang (2020), "Explaining Foreign Support for China's Global Economic Leadership", International Organization, Vol 74, Issue 3, Summer.

Chandrasekhar, C. P. and Jayati Ghosh (2001), Crisis as Conquest: The Southeast Asian Crisis and its Aftermath, New Delhi: Orient Longman.

Chandrasekhar, C. P. and Jayati Ghosh (2013), "Financial Crisis, Financial Restructuring and the Problem of Contagion", in Martin H. Wolfson and Gerald Epstein (eds) (2013), The Handbook of the Political Economy of Financial Crises, Oxford: Oxford University Press. 
Chatzky, Andrew and James McBride (2020), "China's Massive Belt and Road Initiative", Council on Foreign Relations, January 28, 2020 update accessed at https://www.cfr.org/backgrounder/chinas-massive-belt-and-road-initiative.

Chin, Gregory T. and Kevin P. Gallagher, "Coordinated Credit Spaces: The Globalization of Chinese Development Finance", Development and Change, Vol. 50, No. 1.

Cho, Youngwan (2011), “The Chiang Mai Initiative and Its Multilateralization: Toward an Asian Monetary Fund?", Sfera Politicii, 19 (11 (165)), accessed at http://revistasferapoliticii.ro/sfera/165/art11-Cho.php.

Craig, Valentine V. (1998), “Japanese Banking: A Time of Crisis”, FDIC Banking Review, January.

Curran, Enda and Michelle Jamrisko (2000), "The Same Stimulus that Rich Countries Lean on Could Worsen Poor Countries", Bloomberg, April 2, https://www.bloomberg.com/news/articles/2020-04-01/a-mother-of-all-sudden-stops-leavesemerging-markets-in-crisis, accessed April 10, 2020

Di Mauro, Beatrice Weder and Jeromin Zettelmeyer (2017), The New Global Financial Safety Net: Struggling for Coherent Governance in a Multipolar System, Centre for International Governance Innovation, Essays on International Finance, Volume 4, January.

Direction générale du Trésor (French Treasury) (2018), Trésor-Economics No 231, November, Paris: Ministère de l'Économie et des Finances.

Eren, Egemen, Andreas Schrimpf and Vladyslav Shusko (2020a), "US dollar funding markets during the Covid-19 crisis - the money market fund turmoil", BIS Bulletin No. 14, 12 May, Basel: BIS.

Eurostat (2019), Balance of payments - International transactions (BPM6): Reference Metadata in Euro SDMX Metadata Structure (ESMS), available at https://ec.europa.eu/eurostat/cache/metadata/en/bop_6_esms.htm. Accessed 15 July, 2019.

Farrell, Roger and Marie Pangetsu (2007), “The Dynamic In East Asia Investment”, in Mari Pangetsu and Ligang Song (eds.) (2007), Japan's Future in East Asia and the Pacific, ANU Press.

Ferguson, Thomas (2001), "Blowing Smoke: Impeachment, the Clinton Presidency, and the Political Economy", in William J. Crotty (ed.) (2001), The State of Democracy in America, Washington DC: Georgetown University Press.

Fleming, Michael J. and Nicholas J. Klagge (2010), “The Federal Reserve's Foreign Exchange Swap Lines”, Current Issues, Vol 16 No. 4, April 2010, Federal Reserve Bank of New York.

Garcia-Herrero, Alicia and Le Xia (2013), China's RMB bilateral swap agreements: What explains the choice of countries?, BOFIT Discussion Papers 12/2013, Helsinki: Bank of Finland.

Goldberg, L.S. and C. Tille (2008) 'Vehicle Currency Use in International Trade', Journal of International Economics 76(2). 
Goldberg, Linda S., Craig Kennedy, and Jason Miu (2011), “Central Bank Dollar Swap Lines and Overseas Dollar Funding Costs", Federal Reserve Bank of New York Economic Policy Review, May.

Gopinath, Gita (2015), The International Price System, Working Paper no. 21644, National Bureau of Economic Research, October.

Grimes, Willam W. (2011), “The Asian Monetary Fund Reborn? Implications of Chiang Mai Initiative Multilateralization”, Asia Policy, Number 11, January.

Grimes, Willam W. (2009), Currency and Contest in East Asia: The Great Power Politics of Financial Regionalism, Itanca: Cornell University Press.

Gros, Daniel and Angela Capolongo (2020), "Global Currencies During a Crisis: Swap Line Use Reveal the Crucial Ones", Monetary Dialogue Papers, Policy Department for Economic, Scientific and Quality of Life Policies, European Parliament, Luxembourg.

Harding, Robin and John Reed (2020), “Asia-Pacific countries sign one of the largest free trade deals in history", Financial Times, November 15, accessed at https://www.ft.com/content/2dff91bd-ceeb-4567-9f9f-c50b7876adce.

Henning, C. Randall (2002), East Asian Financial Cooperation, Institute for International Economics, available at https://www.piie.com/publications/chapters preview/345/3iie3381.pdf. Accessed 17 February 2020

Hook, Glenn D., Julie Gilson, Christopher W. Hughes and Hugo Dobson (2002), “Japan and the East Asian Financial Crisis: Patterns, Motivations and Instrumentalisation of Japanese Regional Economic Diplomacy", European Journal of East Asian Studies, Vol. 1, No. 2.

Hooyman, Catharina J. (1993), The use of foreign exchange swaps by central banks: A survey, IMF Working Paper WP/93/64, August, Washington D.C.: IMF.

Hornby, Lucy (2019), “China pledges to address debt worries over Belt and Road”, Financial Times, 15 April, https://www.ft.com/content/f7442058-66f9-11e9-9adc-98bf1d35a056

Hyun, Suk and James F. Paradise (2019), Why is there no Asian Monetary Fund, ADBI Working Paper Series No. 1061, December, Tokyo: Asian Development Bank Institute. URL: https://www .adb.org/publications/why-there-no-asian-monetary-fund.

IMF (2000), "Recovery from the Asian Crisis and the Role of the IMF", June, https://www.imf.org/external/np/exr/ib/2000/062300.htm\#: :text=On\%20August\%2020\%2C $\% 201997 \% 2 \mathrm{C} \% 20$ the,over\%20a\%2034\%2Dmonth\%20period.

Iwamoto, Kentaro (2017), 'Looking back at the 'Asian IMF' concept”, (Interview with Eisuke Sakakibara), Nikkei Asian Review, June 22. Available at https://asia.nikkei.com/Economy/Looking-back-at-the-Asian-IMF-concept. Accessed 18 July 2019.

Joy-Perez, Cecilia and Davi Scissors (2018), Be wary of spending on the Belt and Road, American Enterprise Institute Report, November, accessed at https://www .aei.org/researchproducts/report/be-wary-of-spending-on-the-belt-and-road/. 
Kadogawa, Yoichi, Vanne Khut, Li Lian Ong, Chaipat Poonpatpibul, Junko Shimizu and Hongbo Wang (2018), Asia and the CMIM in the evolving International Monetary System, Working Paper WP/18-01, ASEAN+3 Macroeconomic Research Office, March.

Kindleberger, Charles (1973), The World in Depression, 1929-1939, Berkeley: University of California Press.

Klein, Matthew C. and Michael Pettis (2020), Trade Wars are Class Wars: How Rising Inequality Distorts the Global Economy and Threatens International Peace, New Haven: Yale University Press.

Lane, Philip R. and Gian Maria Milesi-Ferretti (2017), "International Financial Integration in the Aftermath of the Global Financial Crisis," IMF Working Paper 17/115.

Liao, Steven and Daniel McDowell (2015), "Redback Rising: China’s Bilateral Swap Agreements and Renminbi Internationalization”, International Studies Quarterly, 59.

Lipscy, Phillip Y. 2003. "Japan's Asian Monetary Fund Proposal.” Stanford Journal of East Asian Affairs 3 (1): 93-104.).

McGuire, P., and Goetz von Peter (2009), "The U.S. Dollar Shortage in Global Banking”, Bank for International Settlements Quarterly Review, March.

Mehrling, Perry (2015), Elasticity and Discipline in the Global Swap Network, Working Paper No. 27, Institute for New Economic Thinking, New York, November 12.

Narine, Shaun (2003), “The Idea of an 'Asian Monetary Fund': The Problems of Financial Institutionalism in the Asia-Pacific", Asian Perspective, Vol 27 No 2.

Nordhaug, Kristen (2000), "Asian monetary fund revival?" Focus on Trade, no. 51, June, available at http://www.focusweb.org/focus/pd/apec/fot/fot51.htm.

Pickard, Jim (2019), "Hammond to seek UK deals in China's Belt and Road Initiative", Financial Times, April 25, accessed at https://www.ft.com/content/9f054218-66af-11e9a79d-04f350474d62.

Pollack, Andrew (1997), "I.M.F., With the Help of Asians, Offers Thais \$16 Billion Bailout", The New York Times, August 12, p. 1. https://www.nytimes.com/1997/08/12/business/imfwith-the-help-of-asians-offers-thais-16-billion-bailout.html.

Ray, Rebecca and Blake Alexander Simmons (2020), "China's Overseas Development Finance Database: Geospatial Data for Analysis of Biodiversity and Indigenous Lands". Accessed at https://www.bu.edu/gdp/2020/12/07/tracking-chinas-overseas-developmentfinance/ on 15 December 2020.

Reis, Ricardo and Saleem Bahaj (2018), "This is the role of central bank swap lines in the global economy", World Economic Forum at https://www.weforum.org/agenda/2018/09/central-bank-swap-lines/.

Scissors, Derek (2020), "China's Global Investment in 2019: Going Out Goes Small”, American Enterprise Institute, January, accessed at https://www .aei.org/wpcontent/uploads/2020/01/Chinas-global-investment-in-2019-1.pdf?x88519. 
Sussangkarn, Chalongphob (2010), The Chiang Mai Initiative Multilateralization: Origin, Development and Outlook, ADBI Working Paper Series No. 230, July.

Sussangkarn, Chalongphob and Worapot Manupipatpong (2015), "A View from ASEAN", in Kawai, Masahiro, Yung Chul Park and Charles Wyplosz (2015), Monetary and Financial Cooperation in East Asia, Oxford: Oxford University Press.

Tett, Gillian (1999), “Japan seeks Asian Monetary Fund”. URL: imfsite.org/reform/japan2.

Wang, Hongying (2015), “The New Development Bank and the Asian Infrastructure Investment Bank: China's Ambiguous Approach to Global Financial Governance", Development and Change, Vol. 50, No. 1.

Wihardja, M. M. (2016), "The Effect of the Commodity Boom on Indonesia's Macroeconomic Fundamentals and Industrial Development”, International Organisation's Research Journal, Vol. 11, No. 1.

World Bank (2010), Boom, Bust and Up Again? Evolution, Drivers and Impact of Commodity Prices: Implications for Indonesia, Jakarta: World Bank Office Jakarta.

Zhang, Fan, Miaojie Yu, Jiantuo Yu \& Yang Jin (2017), “The Effect of RMB Internationalization on Belt and Road Initiative: Evidence from Bilateral Swap Agreements", Emerging Markets Finance and Trade, 53:12.

Zhou, Marrian (2019), "Mahathir: 'We have to go to the Chinese' for infrastructure", Financial Times, October 9, accessed at https://www .ft.com/content/be4c7cd4-e5c3-11e9b112-9624ec9edc59. 


\begin{tabular}{|c|c|c|c|c|c|c|c|c|}
\hline \multirow{2}{*}{\multicolumn{4}{|c|}{ Appendix 1: The evolving East Asian safety net }} & \multirow[b]{2}{*}{ Amount involv } & \multirow{2}{*}{ Contributions } & \multirow{2}{*}{\begin{tabular}{|l|} 
Permitted borrowing \\
\end{tabular}} & \multirow{2}{*}{ Time period } & \multirow[b]{2}{*}{ Monitoring and surveillance } \\
\hline & & Agreement & Members & & & & & \\
\hline August & 1977 & \begin{tabular}{|l} 
Asean Swap \\
Arrangement
\end{tabular} & \begin{tabular}{|l} 
Indonesia, Malaysia, \\
Philippines, Singapore and \\
Thailand
\end{tabular} & $\$ 100$ million & $\$ 20$ million each & $\$ 40$ million & $\begin{array}{l}\text { One, two or three months extendable by } \\
\text { a maximum of an additional three } \\
\text { months }\end{array}$ & None \\
\hline September & 1978 & Supllementary ASA & \begin{tabular}{|l} 
Indonesia, Malaysia, \\
Philippines, Singapore and \\
Thailand
\end{tabular} & $\$ 200$ million & $\$ 40$ million each & $\$ 80$ million & $\begin{array}{l}\text { One, two or three months extendable by } \\
\text { a maximum of an additional three } \\
\text { months }\end{array}$ & None \\
\hline May & 2000 & \begin{tabular}{|l} 
Enhanced ASA as \\
pillar of Chiang Mai \\
Initiative
\end{tabular} & 10 ASEAN countries & $\$ 1$ billion & $\begin{array}{l}\text { Prior ASEAN members also designated as } \\
\text { 'tier } 1 \text { ' members (Brunei, Indonesia, } \\
\text { Malaysia, the Philippines, Singapore and } \\
\text { Thailand) contributed } \$ 150 \text { million each } \\
\text { under the revised arrangement, and the } \\
\text { 'tier } 2 \text { ' members made the following } \\
\text { contributions: Vietnam } \$ 60 \text { million; } \\
\text { Myanmar } \$ 20 \text { million; Cambodia } \$ 15 \\
\text { million; Lao PDR } \$ 5 \text { million. }\end{array}$ & Two times contribution & $\begin{array}{l}\text { One, two, three or six months. Rollover is } \\
\text { permitted subject to a period of not more } \\
\text { than six months in total, inclusive of the } \\
\text { linitial swap period }\end{array}$ & $\begin{array}{l}\text { None for swaps of value up to } 10 \text { per cent of } \\
\text { eligible borrowing quota. IMF programme and } \\
\text { monitoring if borrowingexceeds } 10 \text { per cent of } \\
\text { quota. }\end{array}$ \\
\hline May & 2000 & Bilateral swap agree & $\begin{array}{l}\text { Thirty between each of the } 10 \\
\text { ASEAN countries and People's } \\
\text { Republic of China, Republic of } \\
\text { Korea and Japan, and three } \\
\text { between the Plus } 3 \text {. }\end{array}$ & Negotiated & & & 90 days with 7 renewals of drawings. & $\begin{array}{l}\text { None for swaps of value up to } 10 \text { per cent of } \\
\text { eligible borrowing quota. IMF programme and } \\
\text { monitoring if borrowingexceeds } 10 \text { per cent of } \\
\text { quota. }\end{array}$ \\
\hline November & 2005 & $\begin{array}{l}\text { Enhanced ASA as } \\
\text { pillar of Chiang Mai } \\
\text { Initiative }\end{array}$ & 10 ASEAN countries & $\$ 2$ billion & $\begin{array}{l}\text { Brunei, Indonesia, Malaysia, the Philippines, } \\
\text { Singapore and Thailand contributed \$300 } \\
\text { million each, Vietnam \$120 million; } \\
\text { Myanmar \$40 million; Cambodia \$30 } \\
\text { million; Lao PDR \$10 million. }\end{array}$ & Two times contribution & $\begin{array}{l}\text { One, two, three or six months. Rollover is } \\
\text { permitted subject to a period of not more } \\
\text { than sis months in total, inclusive of the } \\
\text { linitial swap period }\end{array}$ & 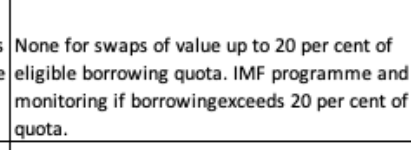 \\
\hline May & 2009 & $\begin{array}{l}\text { CMIM: A single } \\
\text { pooled corpus of } \\
\text { swaps }\end{array}$ & ASEAN +3 & $\$ 120$ billion & $\begin{array}{l}\text { China } \$ 34.2 \text { billion, Hong Kong } \$ 4.2 \text { billion, } \\
\text { Japan } \$ 38.4 \text { billion, Koreea } \$ 19.2 \text { billion, } \\
\text { Indonesia,Malaysia and Singapore } \$ 4.77 \\
\text { billion each, Philippines } \$ 3.68 \text { billion, } \\
\text { Vietnam } \$ 1 \text { billion, Cambodia } \$ 0.12 \text { billion, } \\
\text { Myanmar } \$ 0.06 \text { billion, Brunei and Lao PDR } \\
\text { \$0.03 billion each. } \\
\end{array}$ & \begin{tabular}{|l} 
Purchasing multiples: \\
China 0.5 , Hong Kong \\
2.5, Japan 0.5 , Koreea \\
1 , Indonesia,Malaysia, \\
Singapore and \\
Philippines 2.5 each, \\
Vietnam, Cambodia, \\
Myanmar, Brunei and \\
Lao PDR 5 each. \\
\end{tabular} & $\begin{array}{l}\text { Maturity and supporting period for the } \\
\text { IMF linked portion from } 90 \text { days and } 2 \\
\text { years, respectively, and those for the } \\
\text { IIIF de-linked portion } 90 \text { days and } 1 \text { year } \\
\text { respectively. }\end{array}$ & $\begin{array}{l}\text { None for swaps of value up to } 20 \text { per cent of } \\
\text { eligible borrowing quota. IMF programme and } \\
\text { monitoring if borrowingexceeds } 20 \text { per cent of } \\
\text { quota. Regional monitoring mechanism. }\end{array}$ \\
\hline May & 2012 & $\begin{array}{l}\text { CMIM: A single } \\
\text { pooled corpus of } \\
\text { swaps }\end{array}$ & ASEAN +3 & $\$ 240$ billion & \begin{tabular}{|l} 
China $\$ 34.2$ billion, Hong Kong $\$ 4.2$ billion, \\
Japan $\$ 38.4$ billion, Koreea $\$ 19.2$ billion, \\
Indonesia,Malaysia and Singapore $\$ 4.77$ \\
billion each, Phillippines $\$ 3.68$ billion, \\
Vietnam $\$ 1$ billion, Cambodia $\$ 0.12$ billion, \\
Myanmar $\$ 0.06$ billion, Brunei and Lao PDR \\
$\$ 0.03$ billion each.
\end{tabular} & $\begin{array}{l}\text { Purchasing multiples: } \\
\text { China } 0.5, \text { Hong Kong } \\
\text { 2.5, Japan } 0.5 \text {, Koreea } \\
1 \text {, Indonesia,Malaysia, } \\
\text { Singapore and } \\
\text { Philippines } 2.5 \text { each, } \\
\text { Vietnam, Cambodia, } \\
\text { Myanmar, Brunei and } \\
\text { Lao PDR } 5 \text { each. } \\
\end{array}$ & $\begin{array}{l}\text { Maturity and supporting period for the } \\
\text { IMF linked portion } 1 \text { year and } 2 \text { years, } \\
\text { respectively, and for the IIM de-linked } \\
\text { portion } 6 \text { months and } 2 \text { years, } \\
\text { respectively. }\end{array}$ & $\begin{array}{l}\text { None for swaps of value up to } 30 \text { per cent of } \\
\text { eligible borrowing quota. IMF programme and } \\
\text { monitoring if borrowingexceeds } 30 \text { per cent of } \\
\text { quota. }\end{array}$ \\
\hline Source: Text & it of relev & vant agreements & & & & & & \\
\hline
\end{tabular}

